\title{
Characterization of Sediments from the Soil Desiccation Pilot Test (SDPT) Site in the BC Cribs and Trenches Area
}

$\begin{array}{ll}\text { W Um } & \text { RJ Serne } \\ \text { MJ Truex } & \text { AL Ward } \\ \text { MM Valenta } & \text { CF Brown } \\ \text { C lovin } & \text { KN Geiszler } \\ \text { IV Kutnyakov } & \text { ET Clayton } \\ \text { H Chang } & \text { SR Baum } \\ \text { RE Clayton } & \text { DM Smith }\end{array}$

September 2009

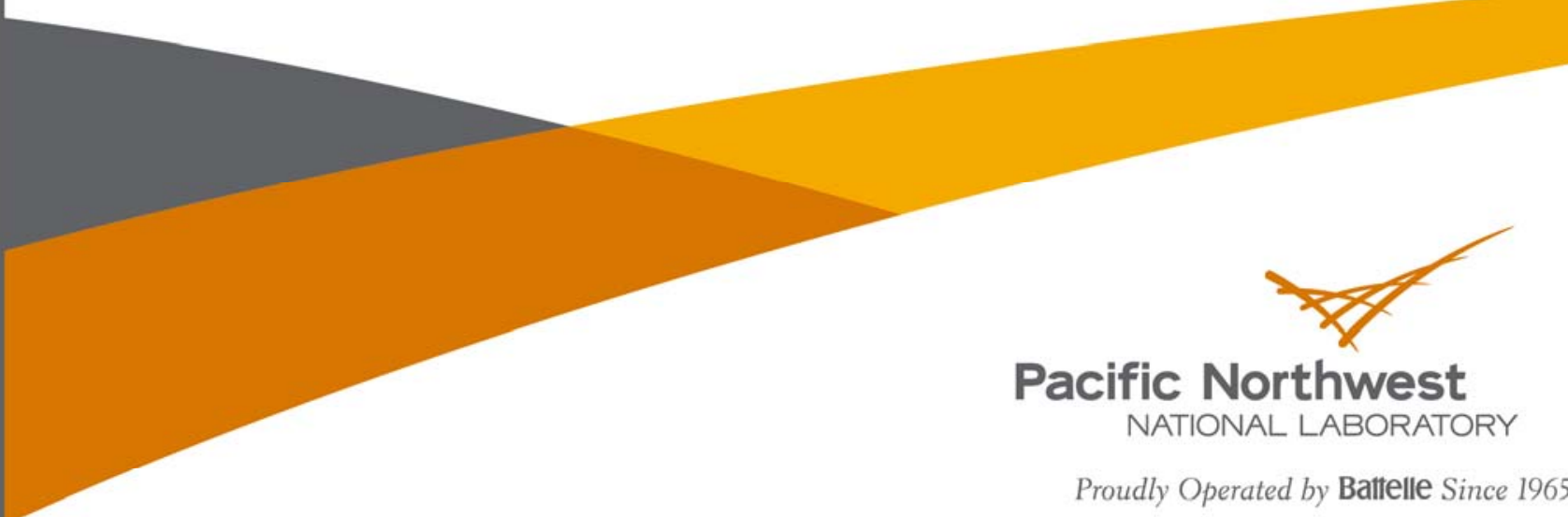




\title{
DISCLAIMER
}

This report was prepared as an account of work sponsored by an agency of the United States Government. Neither the United States Government nor any agency thereof, nor Battelle Memorial Institute, nor any of their employees, makes any warranty, express or implied, or assumes any legal liability or responsibility for the accuracy, completeness, or usefulness of any information, apparatus, product, or process disclosed, or represents that its use would not infringe privately owned rights. Reference herein to any specific commercial product, process, or service by trade name, trademark, manufacturer, or otherwise does not necessarily constitute or imply its endorsement, recommendation, or favoring by the United States Government or any agency thereof, or Battelle Memorial Institute. The views and opinions of authors expressed herein do not necessarily state or reflect those of the United States Government or any agency thereof.

\author{
PACIFIC NORTHWEST NATIONAL LABORATORY \\ operated by \\ BATTELLE \\ for the \\ UNITED STATES DEPARTMENT OF ENERGY \\ under Contract DE-AC05-76RL01830 \\ Printed in the United States of America \\ Available to DOE and DOE contractors from the \\ Office of Scientific and Technical Information, \\ P.O. Box 62, Oak Ridge, TN 37831-0062; \\ ph: (865) 576-8401 \\ fax: (865) 576-5728 \\ email: reports@adonis.osti.gov

\begin{abstract}
Available to the public from the National Technical Information Service, U.S. Department of Commerce, 5285 Port Royal Rd., Springfield, VA 22161 ph: (800) 553-6847 fax: (703) 605-6900 email: orders@ntis.fedworld.gov

online ordering: http://www.ntis.gov/ordering.htm
\end{abstract}




\section{Characterization of Sediments from the Soil Desiccation Pilot Test (SDPT) Site in the BC Cribs and Trenches Area}

$\begin{array}{ll}\text { W Um } & \text { RJ Serne } \\ \text { MJ Truex } & \text { AL Ward } \\ \text { MM Valenta } & \text { CF Brown } \\ \text { C Iovin } & \text { KN Geiszler } \\ \text { IV Kutnyakov } & \text { ET Clayton } \\ \text { H Chang } & \text { SR Baum } \\ \text { RE Clayton } & \text { DM Smith }\end{array}$

September 2009

Prepared for

the U.S. Department of Energy

under Contract DE-AC05-76RL01830

Pacific Northwest National Laboratory

Richland, Washington 99352 


\section{Acknowledgments}

The authors acknowledge the Pacific Northwest National Laboratory staff at the Environmental Sciences Analytical Laboratory who performed all of the sediment sample tests and geochemical parameter analyses. Without their dedicated efforts the large amount of data and quality checks would not have met the expedited schedule required to finish the draft report in a timely fashion. Thanks also to Susan Ennor at PNNL for editorial review and final formatting of this technical report respectively.

Finally, we would like to acknowledge the funding provided by the CH2M HILL Plateau Remediation Contractor (CHPRC) that allowed us to analyze the sediment samples and finish the PNNL report. 



\section{Executive Summary}

This technical report documents the results of laboratory geochemical and hydrologic measurements of sediments collected from new borehole 299-E13-65 (C7047) and comparison of the results with those of nearby borehole 299-13E-62 (C5923) both drilled in the BC Cribs and Trenches Area. The new borehole (C7047) is located between the 216-B-16 and 216-B-17 cribs and about $39.1 \mathrm{ft}$ northeast of adjacent well 299-13E-62 (C5923). Laboratory geochemical and hydrologic characterizations were conducted to provide more data that can be used to support the decision-making related to operating the Soil Desiccation Pilot Test (SPDT) planned near the 299-E13-62 (C5923) well. Another goal of the sediment characterization was to measure the total and water-leachable concentrations of key contaminants of concern (COC) as a function of depth and distances from the footprints of inactive disposal facilities. The total and water-leachable concentrations of key contaminants will be used to update contaminant-distribution conceptual models and to provide more data for improving baseline risk predictions and remedial alternative selections.

Sediment moisture content, contaminant concentration and distribution on sediments, contaminant concentrations in water and acid extracts, and sediment physicochemical properties (such as lithology, particle size analysis, saturated hydraulic conductivity, air permeability, surface area, and cation exchange capacity) were measured to increase our understanding of the sediments existing in the region of the proposed SDPT after comparing them with those from the existing well 299-E13-62 (C5923). In total, 36 grab and core samples were obtained for characterization out of the 28 grab and 24 core samples. Vadose zone sediment samples were obtained at a frequency of about every $2.5 \mathrm{ft}$ from approximately $5 \mathrm{ft}$ below ground surface (bgs)to borehole total depth of $70 \mathrm{ft}$ bgs in C7047. As part of the vadose zone sediment characterization, experienced geologists examined the samples and all available geophysical logging data for the new boreholes and then generated very detailed information on the local stratigraphy in the $\mathrm{BC}$ Cribs and Trenches Area.

The gravimetric moisture contents of the $\mathrm{C} 7047$ sediments range from $2.43 \mathrm{wt} \%$ to $12.7 \mathrm{wt} \%$. The only sediments with high moisture greater than $7.0 \mathrm{wt} \%$ are found in the upper $40 \mathrm{ft}$ bgs, especially between $20 \mathrm{ft}$ and $40 \mathrm{ft}$ bgs. The elevated moisture contents between $20 \mathrm{ft}$ and $40 \mathrm{ft}$ bgs are likely from the fine-grained nature of the sediments in the vadose zone. These fine-grained silty beds are expected to increase lateral spreading of contaminant migration in the upper Hanford formation, because of capillary breaks between fine- and coarse-grained sand. Very similar profiles of moisture contents are found in the two boreholes (C7047 and C5923) sediments, except that higher values of moisture contents were found at the depth of $20 \mathrm{ft}$ to $40 \mathrm{ft}$ bgs in C7047 and lower values were found in the depth of $15.5 \mathrm{ft}$ and 46-48 $\mathrm{ft}$ bgs in C7047 compared to those at the similar depth regions in C5923. Significantly different moisture contents found at both $16 \mathrm{ft}$ and $46 \mathrm{ft}$ bgs between C7047 and C5923 boreholes suggest the possibility of the presence of the fine-grained silty beds (or lenses) discretely located in the shallow depth, even though these two boreholes are located close to each other.

The pore-water chemical composition data show that pore-water electrical conductivity (EC), the concentrations of major ions (sodium and nitrate), and total ionic strength are highly correlated with one another. These values have two elevated lobes in the depth regions of $25 \mathrm{ft}$ to $33 \mathrm{ft}$ bgs and $46 \mathrm{ft}$ to $60 \mathrm{ft}$ bgs of borehole C7047. The deeper lobe at $46 \mathrm{ft}$ to $60 \mathrm{ft}$ bgs has more elevated values compared to those found in the shallower lobe at the depths of $25 \mathrm{ft}$ to $33 \mathrm{ft}$ bgs. The borehole C7047 sediments contain high ionic strength $(>0.3 \mathrm{M})$ reaching to maximum of $4.34 \mathrm{M}$ at $53.5 \mathrm{ft}$ bgs. The highest pore-water EC 
at $\mathrm{C} 7047$ is $456 \mathrm{mS} / \mathrm{cm}$ at $48.5 \mathrm{ft}$ bgs. The concentration of major cations in water extracts of C7047 sediments do not show any distinctive depletion in the divalent cations in the shallowest ion exchange front indicating that waste fluids migrated horizontally into the sediments in the shallow portion of borehole C7047 as opposed to vertically, which is the same condition found in borehole C5923. The vadose zone $\mathrm{pH}$ profiles in water extracts of $\mathrm{C} 7047$ show elevated values $(>9.0 \mathrm{pH})$ indicative of caustic waste in the depth region of $30 \mathrm{ft}$ to $40 \mathrm{ft}$ bgs. The highest $\mathrm{pH}$ found in $\mathrm{C} 7047$ is $9.65 \mathrm{pH}$ at $33.2 \mathrm{ft}$ bgs. Mildly elevated $\mathrm{pH}$ levels between $8.5 \mathrm{pH}$ and $9.0 \mathrm{pH}$ are also found in the depth region of $46 \mathrm{ft}$ to $53 \mathrm{ft}$ bgs and the $\mathrm{pH}$ levels decrease to reach to background Hanford pore water levels $(7.0-8.5 \mathrm{pH})$ below $56 \mathrm{ft}$ bgs. For the sediments where elevated $\mathrm{pH}$ levels were found in the shallow depths, a few of the major elements (aluminum, iron, and manganese) and $\mathrm{PO}_{4}{ }^{3-}$ also show elevated water-extractable concentrations, suggesting that the sediments interact with the caustic-waste fluids through dissolution and precipitation reactions with more leachable amorphous solid phases. The vertical distribution of the $\mathrm{pH}, \mathrm{EC}$, ionic strength, and pore-water concentrations of sodium and nitrate in C0747 are similar to the profiles of C5923, but the values are much higher than those of C5923, especially at the depths of the two lobes.

Two key radioactive contaminants, technetium-99 and uranium-238, along with other trace metals were determined in water and acid extractions. The water-extractable technetium-99 concentrations in borehole $\mathrm{C} 7047$ show elevated technetium-99 concentrations occurring at the same locations as elevated nitrate with maxima of $73 \mathrm{pCi} / \mathrm{g}, 73 \mathrm{pCi} / \mathrm{g}$, and $64.5 \mathrm{pCi} / \mathrm{g}\left(4.3 \times 10^{-3} \mu \mathrm{g} / \mathrm{g}, 4.3 \times 10^{-3} \mu \mathrm{g} / \mathrm{g}\right.$, and $3.8 \times 10^{-3}$ $\mu \mathrm{g} / \mathrm{g}$ ) at $29 \mathrm{ft}, 39 \mathrm{ft}$, and $60 \mathrm{ft}$ bgs. Because they are mobile contaminants, the concentration profile of nitrate and technetium-99 occurs at the same place and distributes in a similar pattern in the Hanford vadose zone. The same sediments contain elevated water-extractable uranium- 238 as high as $1.29 \mu \mathrm{g} / \mathrm{g}$ of dry sediment at the depth of $33.2 \mathrm{ft}$ bgs. Highly elevated uranium- 238 concentrations are found in the depth region of $33 \mathrm{ft}$ to $40 \mathrm{ft}$ bgs where high moisture and elevated $\mathrm{pH}$ levels are found because of the presence of fine-grained silty beds and contact with caustic waste plume. The concentrations of technetium-99 in acid extracts of C7047 are very similar to those of technetium-99 in water extracts. However, much higher concentrations of uranium- 238 were found in acid extracts of C7047 sediments with a maximum value of $3.36 \mu \mathrm{g} / \mathrm{g}$ at $33.2 \mathrm{ft} \mathrm{bgs,} \mathrm{which} \mathrm{is} \mathrm{indicative} \mathrm{of} \mathrm{the} \mathrm{presence} \mathrm{of} \mathrm{uranium}$ (co)precipitates or uranium occlusions within mineral structure. None of the C7047 borehole sediments showed significantly elevated acid-extractable Resource Conservation and Recovery Act metals, mercury, strontium-90, and nickel-63. The gross-alpha and beta results on the sediments were also low and within the range of natural background.

Compared to water-extractable technetium-99 and uranium-238 concentrations in C5923 sediments, C7047 sediments show a similar distribution of technetium-99 between two boreholes except for higher concentrations of technetium-99 at the depths of $22 \mathrm{ft}$ to $33 \mathrm{ft} \mathrm{bgs}$ in C7047 and $36.8 \mathrm{ft}$ and $45.5 \mathrm{ft}$ bgs in C5923. Much higher uranium-238 concentrations in water extracts of C7047 sediments suggest that high uranium contaminants still remain in the uranium-recovery wastes disposed of in the cribs. Higher values of $\mathrm{pH}, \mathrm{EC}$, and ionic strength in the two lobes $(25-33 \mathrm{ft}$ and $46-60 \mathrm{ft} \mathrm{bgs})$, and elevated concentrations of water-extractable technetium-99 and nitrate at shallow depths ( $25 \mathrm{ft}$ and $33 \mathrm{ft} \mathrm{bgs}$ ) of C7047 sediments are attributed to the greater volumes of caustic wastes that have contaminated the C7047 sediments through lateral spreading after being disposed of in the cribs which are located closer to $\mathrm{C} 7047$ than C5923. In addition, even though there are no data for the contaminants on sediments collected at the depth below $70 \mathrm{ft}$ bgs in $\mathrm{C} 7047$ borehole, based on the geochemical characterization results from C7047 
and comparison of them with those of $\mathrm{C} 5923$, the vertical extent of contact with the waste plume might be a bit larger in C7047 than the thicknesses of impacted sediments observed at C5923.

Additional characterization results (particle-size distribution [PSD], surface area analysis [SSA], cation exchange capacity [CEC], saturated hydraulic conductivity, and air permeability) related to hydrologic properties for selected core samples show that $\mathrm{C} 7047$ sediments belong to the sand-dominant Hanford formation $\mathrm{H} 2$ unit with minor variation in clay and gravel contents. The highest gravel content $(8.2 \mathrm{wt} \%)$ was found in the sediment collected at $31.3 \mathrm{ft} \mathrm{bgs}$, which has also high content of silt and clay (33 wt\%). The highest clay-only fraction ( $8.1 \mathrm{wt} \%$ ) was found in sediment at $40.5 \mathrm{ft}$ bgs. In general, most of high values of silt/clay contents ranging from $12 \mathrm{wt} \%$ to $33 \mathrm{wt} \%$ were found in sediments at between $30 \mathrm{ft}$ and $40 \mathrm{ft}$ bgs where elevated moisture contents, $\mathrm{pHs}$, and uranium-238 concentrations were found in previous geochemical characterizations. Compared to PSD results from C5923, C7047 sediments show similar size fractions with less amounts of gravel and clay fractions, but more silt and sand fractions. Because of the high salt concentration, a higher SSA after the washing steps to remove pore-water salts was found in most of the sediments collected at between $31 \mathrm{ft}$ and $46 \mathrm{ft}$ bgs, and the values ranged from $2.17 \mathrm{~m}^{2} / \mathrm{g}$ to $25.1 \mathrm{~m}^{2} / \mathrm{g}$. Compared to the SSA of C5923 sediments, the SSA values collected from C7047 sediments are similar, but slightly higher, especially those collected at shallow depths above $40 \mathrm{ft}$ bgs. The CEC values measured using after-washed sediments of $\mathrm{C} 7047$ ranged from $8.11 \mathrm{meq} / 100 \mathrm{~g}$ to $27.3 \mathrm{meq} / 100 \mathrm{~g}$. Higher CEC ( $>10 \mathrm{meq} / 100 \mathrm{~g}$ ) were also found at the depths between $31 \mathrm{ft}$ and $41 \mathrm{ft}$ bgs where most of high ionic strengths and fine-grained silty beds were found. Compared to CEC in C5923 sediments, the CEC values of C7047 are much higher than those found in C5923, which ranged from $3.23 \mathrm{meq} / 100 \mathrm{~g}$ to $9.28 \mathrm{meq} / 100 \mathrm{~g}$ with a mean value of $7.16 \mathrm{meq} / 100 \mathrm{~g}$.

The measured saturated hydraulic conductivity ranged from a low of $2.55 \mathrm{E}-07 \mathrm{~cm} / \mathrm{sec}$ at $40.5 \mathrm{ft}$ bgs to a high of $1.58 \mathrm{E}-03 \mathrm{~cm} / \mathrm{sec}$ at $49.0 \mathrm{ft}$ bgs with a mean of $3.73 \mathrm{E}-04 \mathrm{~cm} / \mathrm{sec}$. Sediment collected at $40.5 \mathrm{ft}$ bgs showed the lowest hydraulic conductivity because of the high content of clay-sized particles. Compared to measured hydraulic conductivities of C5923, borehole C7047 showed relatively lower hydraulic conductivities than those of C5923. The intrinsic air permeability of C7047 sediments ranged from $2 \times 10^{-12} \mathrm{~m}^{2}$ to $2.73 \times 10^{-10} \mathrm{~m}^{2}$ with a mean value of $4.8 \times 10^{-11} \mathrm{~m}^{2}$ and the pneumatic conductivity was determined to range from $0.039 \mathrm{~cm} / \mathrm{hr}$ to $5.27 \mathrm{~cm} / \mathrm{hr}$ with a mean value of $0.93 \mathrm{~cm} / \mathrm{hr}$. Compared to measured air permeability values in C5923 sediments collected at the depths above $70 \mathrm{ft} \mathrm{bgs,}$, borehole C7047 sediments showed similar, but slightly higher values than those of C5923 sediments. In general, samples with high moisture content are typically finer in texture and also exhibit low conductivities for both air and water flow than coarser and drier samples. However, sediments showing the lowest hydraulic conductivity collected at $40.5 \mathrm{ft}$ bgs did not exhibit the lowest air permeability among sediments collected in C7047. Because the hydraulic conductivity and air permeability of sediment depend on porosity, pore-size distribution, pore shape, pore tortuosity, and connectivity in soils, more careful measurements should be conducted to compare the data with each other.

Based on the geochemical and hydrologic characterization results described above, greater volumes of wastes appear to have contacted the sediments of borehole C7047 than contacted the shallow sediments at borehole C5923. Additional geochemical and hydrologic data were obtained to provide realistic information for the design and operation of the soil desiccation system that is planned at the BC Cribs and Trenches Area. In addition, the total and water-leachable concentrations of key contaminants of concern as a function of depth and distance from the footprints of inactive disposal facilities were measured, and these results will be used to update contaminant-distribution conceptual models and to provide more data for improving baseline risk predictions and remedial alternative selections at the Hanford Site. 



\section{Acronyms and Abbreviations}

BET

bgs

CEC

CHPRC

$\mathrm{COC}$

DI

DOE

DVZTT

EC

EPA

ESL

FHI

GEA

HASQARD

HEIS

IC

ICP-MS

ICP-OES

ID

$\mathrm{K}_{\mathrm{w}}$

$\mathrm{K}_{\mathrm{a}}$

PNNL

PSD

RCRA

$\mathrm{RL}$

SSA

USGS
Brunauer-Emmett-Teller - method used to measure specific surface area of solid below ground surface

cation exchange capacity

CH2M HILL Plateau Remediation Contractor

contaminant of concern

deionized

U.S. Department of Energy

Deep Vadose Zone Treatability Test

electrical conductivity - measure of salt content in fluid

U.S. Environmental Protection Agency

Environmental Sciences Laboratory

Fluor Hanford, Inc.

gamma energy analysis

Hanford Analytical Services Quality Assurance Requirements Document Hanford Environmental Information System

ion chromatography - used to measure anions concentrations

inductively coupled plasma mass spectroscopy

inductively coupled plasma optical emission spectroscopy

identification

saturated hydraulic conductivity

air permeability

Pacific Northwest National Laboratory

particle-size distribution

Resource Conservation and Recovery Act

(DOE's) Richland Operations Office

specific surface area

United States Geological Society 


\section{Units of Measure}

\begin{tabular}{|c|c|}
\hline$\%$ & percent \\
\hline${ }^{\circ} \mathrm{C}$ & temperature in degrees Celsius $\left[\mathrm{T}\left({ }^{\circ} \mathrm{C}\right)=\mathrm{T}(\mathrm{K})-273.15\right)$ \\
\hline $\mathrm{Ci}$ & curie \\
\hline $\mathrm{cm}$ & centimeter \\
\hline $\mathrm{ft}$ & foot \\
\hline $\mathrm{g}$ & gram \\
\hline$g$ & acceleration due to gravity \\
\hline$\mu$ & micro (prefix, 10-6) \\
\hline$\mu \mathrm{Ci}$ & microcurie \\
\hline$\mu \mathrm{eq}$ & microequivalent \\
\hline$\mu \mathrm{g}$ & microgram \\
\hline$\mu \mathrm{m}$ & micrometer \\
\hline $\mathrm{m}$ & meter \\
\hline M & molarity, mol/L \\
\hline $\mathrm{meq} / \mathrm{L}$ & milli-equivalent per liter \\
\hline $\mathrm{mg}$ & milligram \\
\hline $\mathrm{mL}$ & milliliter \\
\hline $\mathrm{mm}$ & millimeter \\
\hline $\mathrm{mM}$ & millimolar \\
\hline $\mathrm{mN}$ & millinormal \\
\hline mol & mole \\
\hline $\mathrm{mS}$ & milliSiemen \\
\hline $\mathrm{N}$ & Normal \\
\hline $\mathrm{nCi}$ & nanocurie \\
\hline ng & nanogram \\
\hline $\mathrm{pCi}$ & picocurie \\
\hline $\mathrm{wt} \%$ & weight percent \\
\hline
\end{tabular}




\section{Contents}

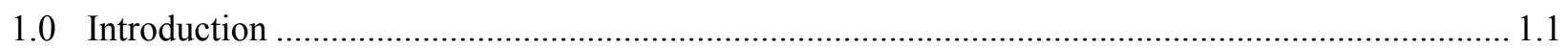

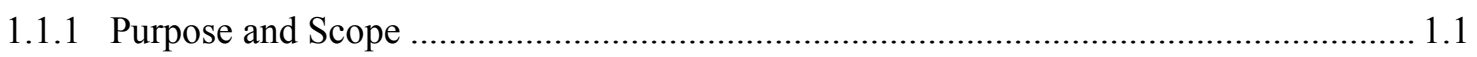

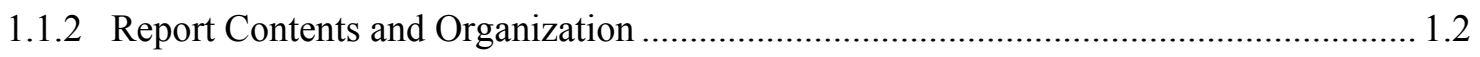

2.0 Geochemical/Hydrological Methods and Materials .................................................................. 2.1

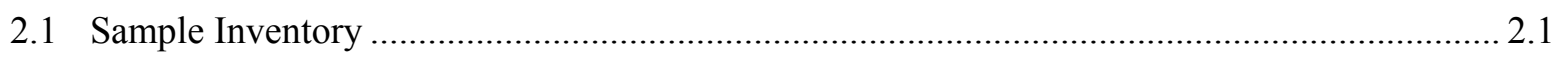

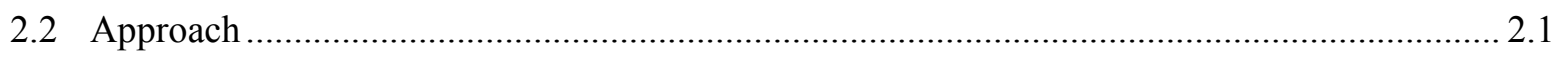

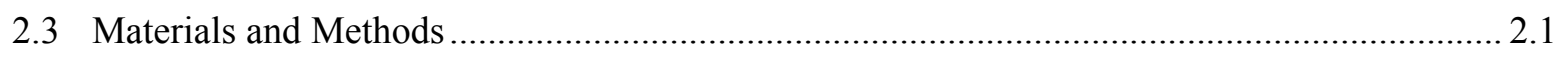

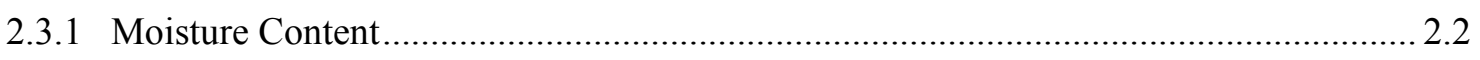

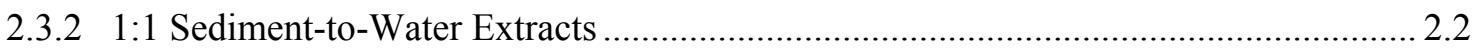

2.3.3 8-M Nitric Acid Extracts and Elemental Analysis .................................................... 2.3

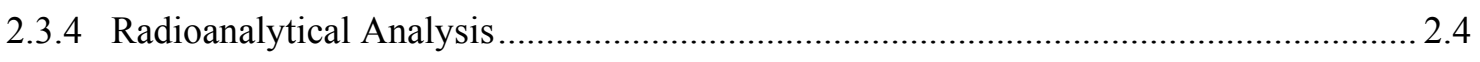

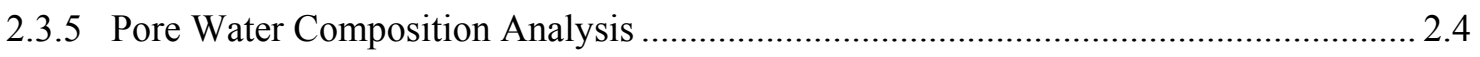

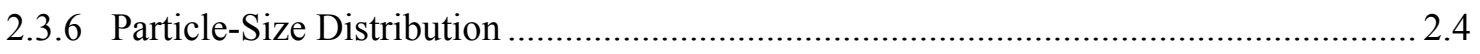

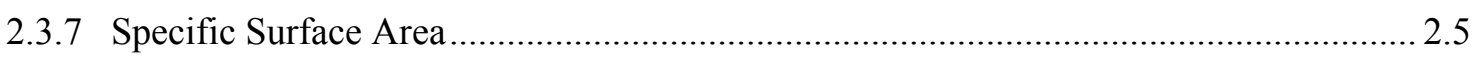

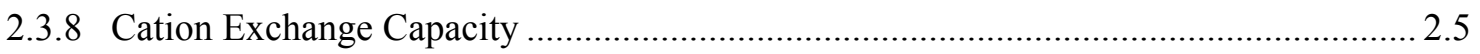

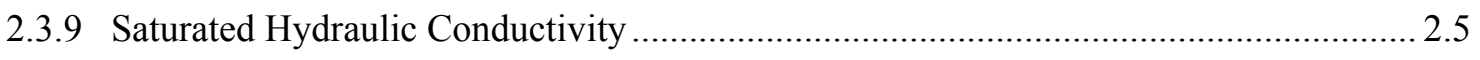

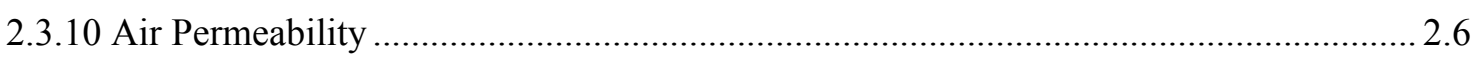

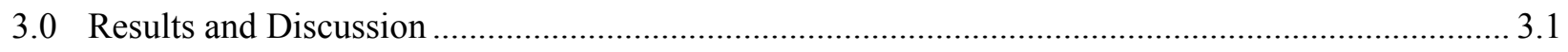

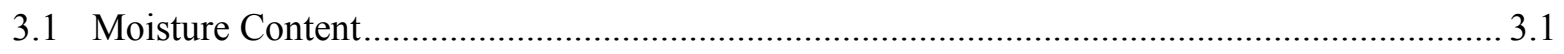

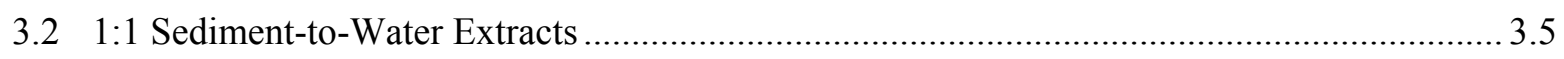

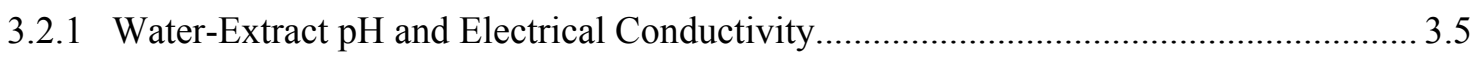

3.2.2 Water Extract Composition for C7047 ................................................................. 3.9

3.2.3 8-M Nitric Acid Extracts and Gamma Energy Analysis Results ................................ 3.16

3.2.4 Particle-Size Distribution of Sediments in Borehole C7047 ...................................... 3.18

3.2.5 Specific Surface Area and CEC of Vadose Sediments from Borehole C7047 ........... 3.20

3.2.6 Saturated Hydraulic Conductivity and Air Permeability of Sediments from

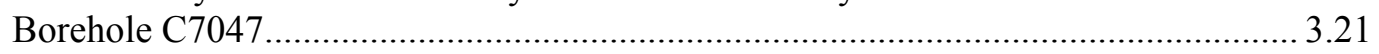

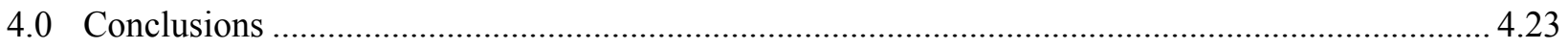

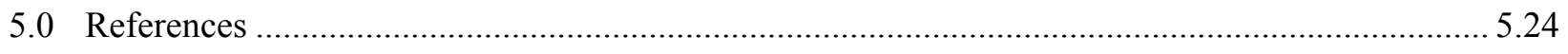

Appendix A Well Summary, Borehole Logs, and Geologic Logs for Borehole 299-E13-65

(C7047) in the BC Cribs and Trenches Area........................................................................ A.1

Appendix B Photographs of Sediment Samples Opened in the Lab from Borehole 299-E13-65

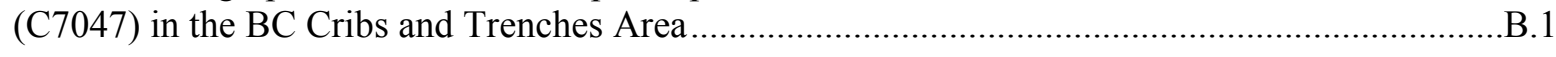

B.1 Samples from Borehole C7047 (299-E13-65).....................................................................3

B.2 Core Sample used for Saturated Hydraulic Conductivity from Borehole C7047 (299E13-65). 


\section{Figures}

Figure 1.1. Borehole and Direct-Push Technology Locations in the BC Cribs and Trenches Area ......... 1.2

Figure 3.1. Composite Summary Log for Borehole C7047 with Laboratory Moisture from C5923 for

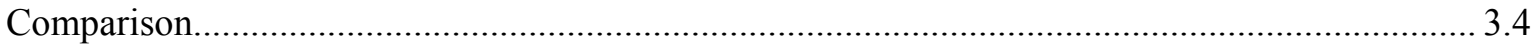

Figure 3.2. Measured pHs in Water Extracts for 299-E13-65 (C7047) Borehole Sediments ................... 3.6

Figure 3.3. Pore-Water EC, Ionic Strength and Major Ions in Borehole 299-E13-65 (C7047) with

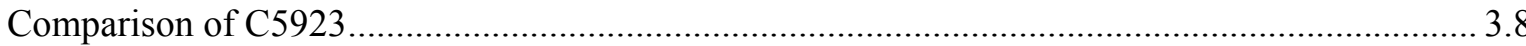

Figure 3.4. Water-Extractable Technetium-99 and Uranium-238 in Sediments from Borehole C7047 in

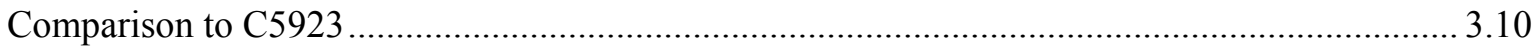

Figure 3.5. Acid-Extractable Technetium-99 (left) and Uranium-238 (right) in Sediments from Borehole C7047 with Comparison of Water-Extractable Technetium and Uranium-238 from C5923 and C7047

Figure 3.6. Particle-Size Distribution of the Selected Core Sediments from Borehole C7047. Lines with symbols indicate date from sieve and lines without symbols are from hydrometer analyses ....... 3.19 


\section{Tables}

Table 3.1. Grab and Core Samples Collected from Borehole 299-E13-65 (C7047) ............................. 3.1

Table 3.2. pH and EC Values for 1:1 Sediment-to-Water Extracts from C7047 .................................. 3.6

Table 3.3. Anion Composition of Water Extracts of C7047 ( $\mu \mathrm{g} / \mathrm{g}$ dry sediment) ................................ 3.11

Table 3.4. Water-Extractable Anions Converted to Pore-Water Concentrations for C7047 Borehole

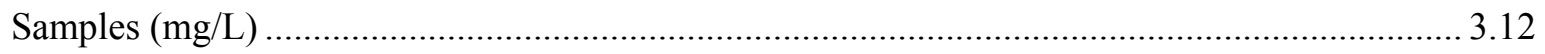

Table 3.5. Water Extractable Cations in Borehole C7047 Sediments ( $\mu \mathrm{g} / \mathrm{g}$ dry soil) ......................... 3.13

Table 3.6. Water-Extractable Cations as Pore-Water Concentrations in Borehole C7047 Sediments

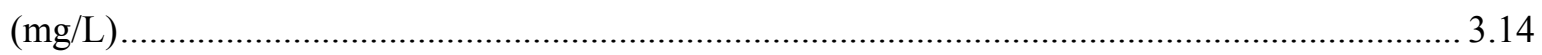

Table 3.7. Water-Extractable Radionuclides and Pore-Water Total Ionic Strength for C7047 Sediments3.15

Table 3.8. Acid-Extractable Radionuclides in Borehole C7047 Sediments ....................................... 3.17

Table 3.9. Manmade Fission Product GEA Data (pCi/g sediment) for Core Samples from C7047 ....... 3.18

Table 3.10. Particle-Size Distributions as Determined by the Dry Sieve/Hydrometer Method for Core

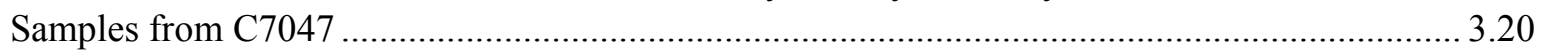

Table 3.11. SSA and CEC for Borehole C7047 Vadose Zone Sediments ............................................ 3.21

Table 3.12. Saturated Hydraulic Conductivity and Air-Permeability Measurements for Borehole C7047

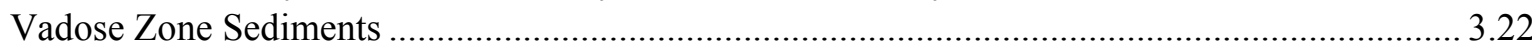




\subsection{Introduction}

The radioactive liquid wastes, nearly 2 trillion liters (450 billion gallons) generated by the U.S. Department of Energy (DOE) over decades of operation are being stored at the Hanford Site (DOE 2007). Some of this waste has been released into the vadose zone at the Hanford Site called the Central Plateau and reached groundwater by percolating through the vadose zone. Two contaminants, technetium-99 and uranium-238, are considered to the major contaminants of concern (COC) at the Hanford Site because they are mobile in the subsurface environments and have been detected at high concentrations deep in vadose zone and groundwater. Although widely distributed contaminants have been detected, however, in situ technologies of remediation for application to the Hanford deep vadose zone are not developed and tested sufficiently to enable adequate evaluation as remedial alternatives (DOE 2007). Therefore, treatability studies have been established to provide the data for the design and operation of necessary technology and implement a cost effective remedy for technetium-99 and uranium238 in the vadose zone at the Hanford Site. The improved understanding of subsurface conditions and methods to remediate these principle contaminants can be also used to valuate the application of specific technologies to other contaminants across the Hanford Site.

The Deep Vadose Zone Treatability Test (DVZTT) within the Soil \& Groundwater Remediation Project was designed to provide science and technology for the soil desiccation remediation by laboratory testing, modeling and simulation, additional field test site characterization and soil sample analyses, and development of inputs for soil desiccation test system. Soil desiccation remedy, the top selected treatability technology, was recommended to remediate contaminants present in vadose zone pore water by removing water from the vadose zone with injecting dry air. Promisingly, soil desiccation can remove pore water in the vadose zone, it reduces the amount of pore fluid as well as the mobility of water and contaminant in the deep vadose zone (DOE 2007).

The overall goal of the soil characterization effort, one of the DVZTT tasks as described above, is to provide data and analyses to support the decisions to be made in designing and operating the Soil Desiccation Pilot Test (SDPT) in the BC Cribs and Trenches Area. For a more complete discussion of characterization of the soil desiccation pilot test site, see the overall work plan, Sampling and Analysis Plan for Characterization of the Soil Desiccation Pilot Test Site (DOE/RL -2008-67 Rev.0). To meet the associated characterization goals, the CH2M HILL Plateau Remediation Contractor (CHPRC) asked scientists from Pacific Northwest National Laboratory (PNNL) to perform detailed analyses of vadose zone sediments collected from a new drilled borehole 299-E13-65 (C7047) in the BC Cribs and Trenches Area.

\subsubsection{Purpose and Scope}

Under this characterization study, borehole 299-E13-65 (C7047) was drilled to enable the collection, measurement, and analysis of grab and core sediment samples to augment data previously collected from adjacent borehole 299-E13-62 (C5923), which is located about $39.1 \mathrm{ft}$ southwest of C7047 between the 216-B-16 and 216-B-17 cribs (as shown in Figure 1.1). Sediment sampling and laboratory analysis of borehole sediments were conducted to provide information that is a key to determining the vertical distribution of mobile contaminants, moisture contents, and major solutes in the vadose zone pore water to support groundwater remediation related to final site cleanup. The data and analyses described in this report are designed to provide additional information for direct measurements of geochemical, 
hydrological, and soil properties of subsurface sediments collected from the new borehole, 299-E13-65 (C7047) and compare them with those previously collected data from existing borehole 299-13E-62 (C5923) in order to build more robust sediments characterization database. The total and water-leachable concentrations of key contaminants of concern, especially technetium-99 and uranium-238 in the sediments as a function of depth, and their distances from inactive disposal facilities were also collected to develop an additional database for a contaminants depth profile in the BC Cribs and Trenches Area. Water extracts taken from the sediments were used for electrical conductivity (EC), common cation and anion concentrations, $\mathrm{pH}$, and alkalinity. Pore-water ionic strength was calculated based on the concentrations of major cations and anions. The total and water-leachable concentrations of key contaminants will be used to update contaminant-distribution conceptual models and to provide more data for improving baseline risk predictions and remedial alternative selections.

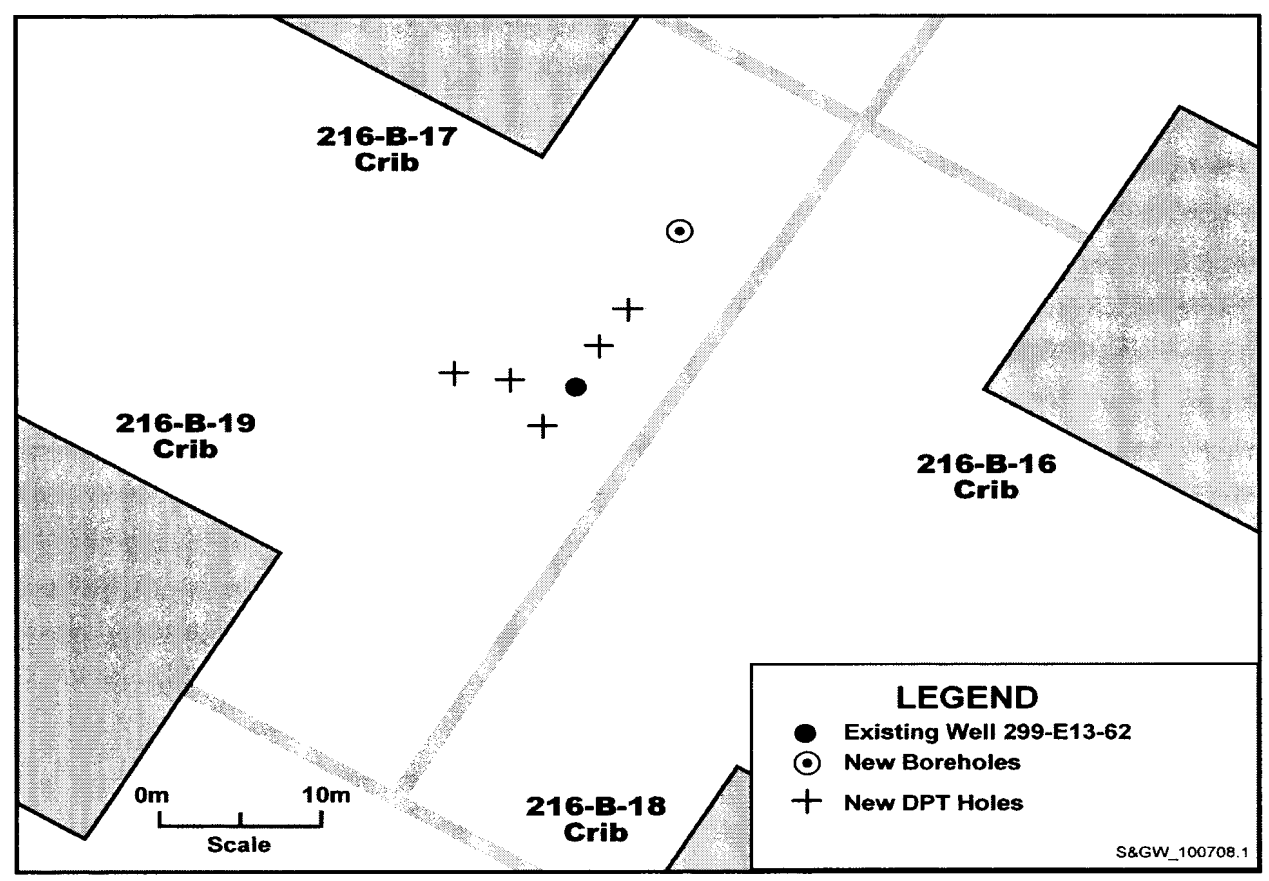

Figure 1.1. Borehole and Direct-Push Technology Locations in the BC Cribs and Trenches Area

All of the data collected on the borehole sediments in this report can be used for soil desiccation groundwater remediation to remove the contaminants of concern and for development of conceptual models for the contaminants' distribution in the subsurface and future potential mobility. Newly added data and analyses can also inform DOE decision-making about the near-term operations, future waste site remediation, and final closure activities for inactive disposal facilities.

\subsubsection{Report Contents and Organization}

This report contains of all the measured geochemical and hydrological characterization data collected on vadose zone sediments recovered from new borehole 299-E13-65 (C7047) placed next to existing 29913E-62 (C5923) borehole within the BC Cribs and Trenches Area. It also interprets data in the context of the vertical extent of contamination, the migration potential of the contaminants that still reside in the vadose zone, and the correspondence of the contaminant distribution in the borehole sediment to 
groundwater plumes in the unconfined aquifer proximate and downgradient from the BC Cribs and Trenches Area. The ensuing sections of this report describe the geochemical and hydrological characterization methods, and discuss geochemical and hydrological results, and summarize findings and conclusions. Appendices A and B provide additional details, including borehole driller's well summary, borehole logs, and geologic logs and sediment grab/core-sample photographs. 


\subsection{Geochemical/Hydrological Methods and Materials}

The following sections describe the methods and philosophy used to characterize the sediments collected from borehole 299-E13-65 (C7047) in the BC Cribs and Trenches Area and the parameters that were measured and analyzed in the laboratory. The materials and methods used to conduct analyses of the geochemical, hydrological, and physical properties of the sediments are also described.

\subsection{Sample Inventory}

The Hanford Environmental Information System (HEIS), a consolidated set of electronic systems that manage data collected during environmental monitoring, was used to name samples for specific sample identification (ID) numbers assigned by Fluor Hanford, Inc. (FHI). The core samples from split-spoon core sampling at borehole 299-E13-65 (C7047) were further identified by the numbers 1, 2, 3, or 4, where the number 1 liner was always in the deeper position closest to the drive shoe. Four 0.5 -ft Lexan liners were emplaced within the split-spoon coring device. After discarding liner 4 (top liner) as slough and using liner 1 and the core barrel drive shoe to generate a composite grab sample, liners 2 and 3 were generally sent to the PNNL environmental science laboratory in an intact condition. Drilling for borehole 299-E13-65 (C7047) reached a depth of $70 \mathrm{ft}(21.4 \mathrm{~m})$ below ground surface (bgs). Both core liners (total 24) and grab samples (total 28) were received from borehole 299-E13-65 (C7047). Additional laboratory duplicate samples were generated during sub-sampling so that Hanford Analytical Services Quality Assurance Requirements Document (HASQARD) quality assurance and/or quality control protocols could be met. The PNNL document for implementing HASQARD is PNNL-SA-63118, Conducting Analytical Work in Support of Regulatory Programs. Details about the core and grab samples received from borehole 299-E13-65 (C7047) are listed in Table 3.1.

\subsection{Approach}

Based on past borehole characterization investigations of Hanford sediments, a method was developed to select samples that considered depth, geology (e.g., lithology, grain-size composition, and carbonate content), contaminant concentration (e.g., radionuclides, metal, and nitrate), moisture content, and overall sample quality. Extraction and leaching procedures were performed and certain key parameters (i.e., moisture content, gamma energy analysis [GEA]) were measured on each sediment sample. During the geologic examination of the grab samples, the sediment contents were sub-sampled for moisture content, gamma-emission radiocounting, 1:1 water extractions (which provide soil $\mathrm{pH}$, alkalinity, EC, cation and anion data, and ionic strength calculation), cation exchange capacity (CEC), and surface area measurement. Sampling preference was always biased toward the finer-grained and/or wetter material contained in each grab sample. The remaining sediment from each grab sample was then sealed and placed in cold storage. Selected core samples based on previous characterization results from grab samples were also used for measuring saturated hydraulic conductivity, air permeability, 1:1 water extracts, CEC, and surface area analysis.

\subsection{Materials and Methods}

During sub-sampling, every effort was made to minimize moisture loss and prevent cross contamination between samples. Depending on the sample matrix, very coarse pebbles and larger 
material (i.e., $>32 \mathrm{~mm}$ ) were removed during sub-sampling. Larger substrate was excluded to achieve moisture contents that were representative of GEA and 1:1 ratio of sediment-to-water-extraction samples. Therefore, the results from the sub-sample measurements may contain a possible bias toward higher concentrations for some analytes that would be preferentially associated with the smaller sized sediment fractions.

Procedures ASTM D2488-93 (ASTM 1993) and PNL-MA-567-DO-1 (PNL 1990) were followed for visual descriptions and geological descriptions of all samples. The sediment classification scheme used for geologic identification of the sediment types (used solely for graphing purposes in this report) was based on the modified Folk (1968) and Wentworth (1922) classification scheme.

This section also describes the laboratory methods used to characterize the hydrologic properties of the soil samples collected from borehole 299-E13-65 (C7047). Laboratory measurements were performed on intact cores and grab samples to characterize hydrologic soil properties. Measured properties included particle-size distribution (PSD), specific surface area (SSA), saturated hydraulic conductivity $\left(\mathrm{K}_{\mathrm{w}}\right)$, and air permeability $\left(\mathrm{K}_{\mathrm{a}}\right)$. Ten core samples were selected for particle-size analysis and surface area measurements. In general, samples were specifically selected from fine-grained silty beds (or lenses) and the first coarse-textured layer occurring beneath each fine layer, i.e., layer sequences that might constitute a capillary break.

\subsubsection{Moisture Content}

The gravimetric water contents of the sediment samples were determined using PNNL procedure PNNL-AGG-WC-001 (PNNL 2005). This procedure is based on the American Society for Testing and Materials (ASTM) procedure ASTM D2216-98, Test Method for Laboratory Determination of Water (Moisture) Content of Soil and Rock by Mass () 1998). One representative sub-sample of at least $15 \mathrm{~g}$ to $70 \mathrm{~g}$ was used. Sediment aliquots were placed in tared containers, weighed, and dried in an oven at $105^{\circ} \mathrm{C}$ until constant weight was achieved, which took at least 24 hours. The containers were removed from the oven, sealed, cooled, and weighed. At least two weighings, each after a 24-hour heating period, were performed to verify that all moisture was removed. All weighings were performed using a calibrated balance. A calibrated weight set was used to verify balance performance before weighing the samples. The gravimetric water content was computed as the percentage of change in soil weight before and after oven drying.

\subsubsection{1:1 Sediment-to-Water Extracts}

Water-soluble inorganic constituents were determined using a 1:1 sediment-to-de-ionized (DI)-water extract method. The extracts were prepared by adding an exact weight of DI water to approximately $60 \mathrm{~g}$ to $80 \mathrm{~g}$ of sediment (post air-drying and sieving). The weight of DI water needed was determined based on the weight of the air-dried samples (residual moisture in the air-dried samples was considered negligible). An appropriate amount of DI water was added to screw-cap jars containing the sediment samples. The jars were sealed and briefly shaken by hand and then placed on a mechanical orbital shaker for 1 hour. The samples were allowed to settle overnight until the supernatant liquid was fairly clear. The supernatant was carefully decanted, filtered (passed through $0.45-\mu \mathrm{m}$ membranes), and analyzed for conductivity, $\mathrm{pH}$, anions, cations, alkalinity, and radionuclide content. More procedural details can be found in the report by Rhoades (1996) and in Methods of Soils Analysis - Part 3 (ASA 1996). 


\subsubsection{1 pH and Conductivity}

Two aliquots of approximately 3-mL volume of the 1:1 sediment-to-water extract supernatants were used for $\mathrm{pH}$ and conductivity measurements. The $\mathrm{pH}$ of the extracts was measured with a solid-state $\mathrm{pH}$ electrode and a $\mathrm{pH}$ meter calibrated with buffers 7 and 10. The EC was measured using a Pharmacia Biotech Conductivity Monitor. Approximately $2 \mathrm{~mL}$ to $3 \mathrm{~mL}$ of filtered sample were measured in the conductivity meter and compared to potassium chloride standards with a range of $0.001 \mathrm{M}$ to $1.0 \mathrm{M}$.

\subsubsection{Anions}

The 1:1 sediment-to-water extracts were analyzed for anions using ion chromatography (IC). Fluoride, chloride, nitrite, bromide, nitrate, phosphate, and sulfate were separated on a Dionex AS17 column with a gradient elution of $1-\mathrm{mM}$ to $35-\mathrm{mM}$ sodium hydroxide and measured using a conductivity detector. This methodology is based on U.S. Environmental Protection Agency (EPA) Method 300.0A (EPA 1984) with the exception of using the gradient elution of sodium hydroxide.

\subsubsection{Cations and Trace Metals}

Major cation analysis was performed using an inductively coupled plasma-optical emission spectroscopy (ICP-OES) unit using high-purity calibration standards to generate calibration curves and verify continuing calibration during the analysis run. Dilutions of $100 \times, 50 \times, 10 \times$, and $5 \times$ were made of each 1:1 water extraction for analysis to investigate and correct for matrix interferences. Details of this method are found in EPA Method 6010B (EPA 2000b). Analysis of trace metals, including technetium99 and uranium-238, was conducted using an inductively coupled plasma-mass spectrometer (ICP-MS) following the PNNL-AGG-415 method (PNNL 1998), which is quite similar to EPA Method 6020 (EPA 2000c).

\subsubsection{Alkalinity}

Alkalinity was measured using a standard titration with acid method. The alkalinity procedure is equivalent to the U.S. Geological Survey method in the National Field Manual for the Collection of Water-Quality Data (USGS 2004). Measured alkalinity ( $\mathrm{mg} / \mathrm{L}$ as $\mathrm{CaCO}_{3}$ ) was converted to determine $\mathrm{CO}_{3}{ }^{2-}$ concentration in solution.

\subsubsection{8-M Nitric Acid Extracts and Elemental Analysis}

Approximately $20 \mathrm{~g}$ of oven-dried sediment was contacted with 8-M nitric acid at a ratio of approximately five parts acid to one part sediment. The slurries were heated to about $80{ }^{\circ} \mathrm{C}$ for several hours, and then the fluid was separated by filtration through $0.2-\mu \mathrm{m}$ membranes. The acid extractions were analyzed for major cations and trace metals using ICP-OES and ICP-MS techniques, respectively, to determine the elemental composition of the bulk sediment samples. The acid digestion procedure is based on EPA SW-846 Method 3050B (EPA 2000a). 


\subsubsection{Radioanalytical Analysis}

The GEA was performed on 10 selected core sediments after measuring hydraulic properties. All samples for GEA were analyzed using $60 \%$ efficient intrinsic germanium gamma detectors. All germanium counters were efficiency calibrated for distinct geometries using mixed gamma standards traceable to the National Institute of Standards and Technology. Field-moist samples were placed in $150-\mathrm{cm}^{3}$ counting containers and analyzed for 100 minutes in a fixed geometry. All of the measured spectra for samples were background-subtracted. Spectral analysis was conducted using libraries containing most mixed fission products, activation products, and natural decay products. Control samples were run throughout the analysis to verify correct operation of the detectors. The controls contained isotopes with photo peaks spanning the full detector range and were monitored for peak position, counting rate, and full-width half-maximum. Procedural details are found in Gamma Energy Analysis, Operation, and Instrument Verification using Genie2000 ${ }^{\mathrm{TM}}$ Support Software (PNNL 1997).

\subsubsection{Pore Water Composition Analysis}

Major cations $\left(\mathrm{Na}^{+}, \mathrm{Ca}^{2+}, \mathrm{K}^{+}, \mathrm{Mg}^{2+}\right.$, and $\left.\mathrm{Ba}^{2+}\right)$ and anions $\left(\mathrm{NO}_{3}^{-}, \mathrm{PO}_{4}{ }^{3-}, \mathrm{CO}_{3}{ }^{2-}, \mathrm{SO}_{4}{ }^{2-}, \mathrm{Cl}^{-}, \mathrm{F}^{-}\right.$, and, when present, $\mathrm{NO}_{2}{ }^{-}$) concentrations measured from both 1:1 water extracts were used to determine the total inorganic salt concentration and the ionic strength (moles/L). The total ionic strength $(\mathrm{M})$ of the pore water was calculated by the molar concentration of each ionic species multiplied by its charge squared:

$$
I=\frac{1}{2} \sum_{i} C_{i} Z_{i}^{2}
$$

where $\mathrm{C}_{i}$ is the molar concentration (moles/L) of each ionic species, and $\mathrm{Z}$ is the charge valence of each ionic species.

Equivalents of both cations and anions were also determined by the measured molar concentration multiplied by its charge valence. Equivalents of total cation and anion species were used to calculate the charge balance of measured ionic species in pore water as follows:

$$
A B S\left[\frac{(\text { cations }- \text { anions })}{(\text { cations }+ \text { anions })}\right]
$$

where ABS is the absolute value and cations and anions are total cation and anion concentrations with respect to equivalents.

\subsubsection{Particle-Size Distribution}

The dry sieving and hydrometer methods were used to determine the PSD for 10 selected core samples. The method is based on the ASTM procedure ASTM Method D422-63, Standard Test Method for Particle-Size Analysis of Soils (2006a). The silt/clay, sand, and gravel size fractions were separated by sieving. The silt and clay size fractions were further separated using Stokes law (Lamb 1994) settling velocities to determine the weight percentage of each size fraction. 


\subsubsection{Specific Surface Area}

The SSA was measured with a Micromeritics ASAP 2020 gas sorption surface-area analyzer using the $\mathrm{N}_{2}$ - Brunauer-Emmett-Teller (BET) method (Brunauer et al. 1938). The samples were outgassed for a minimum of 5 hours at $110^{\circ} \mathrm{C}$ and at $3-\mu \mathrm{m} \mathrm{Hg}$ pressure. Because the instrument glassware had a narrow neck ( 0.9-cm inner diameter), particles larger than $7 \mathrm{~mm}$ were excluded for measuring the surface area. The SSA was measured at liquid nitrogen temperature (approximately $77 \mathrm{~K}$ ) to allow any $\mathrm{N}_{2}$ molecules to adsorb at the solid surface. The BET method is well known and is given by:

$$
\frac{p}{V_{a}\left(P_{O}-P\right)}=\frac{1}{V_{m} C}+\frac{C-1}{V_{m} C}\left(\frac{P}{P_{o}}\right)
$$

where:

$$
\begin{aligned}
& \mathrm{V}_{\mathrm{a}}=\text { the quantity of gas adsorbed at pressure } \mathrm{P} \\
& \mathrm{V}_{\mathrm{m}}=\text { the quantity of gas adsorbed to form a complete monolayer } \\
& \mathrm{P}_{\mathrm{o}}=\text { the saturation pressure of the gas } \\
& \mathrm{C}=\text { the BET constant. }
\end{aligned}
$$

The values of $\mathrm{V}_{\mathrm{m}}$ and $\mathrm{C}$ are determined by a regression line of the adsorption isotherm plotted with $\mathrm{P} / \mathrm{V}_{\mathrm{a}}\left(\mathrm{P}_{\mathrm{o}}-\mathrm{P}\right)$ vs. $\mathrm{P} / \mathrm{P}_{\mathrm{o}}$. The SSA of a solid is determined by:

$$
\text { Area }=\frac{V_{m}}{22414} a_{m} N_{A} 10^{-20}
$$

where $\mathrm{a}_{\mathrm{m}}$ is the average area occupied by a single adsorbate molecule and NA is Avogadro's number (Gregg and Sing 1982, Webb and Orr 1997).

\subsubsection{Cation Exchange Capacity}

The CEC of 10 selected core samples from borehole 299-e13-65 (C7047) sediments was measured by taking $15 \mathrm{~g}$ of distilled water pre-rinsed (three short-duration rinses) air-dried sediment and extracting one time with 1.0-M ammonium acetate $(35 \mathrm{~mL})$ to prevent additional dissolution of calcium carbonate. The sediment-ammonium acetate slurries were gently shaken on a linear shaker for 24 hours and then centrifuged. Each supernatant solution was filtered through a $0.2-\mu \mathrm{m}$ membrane. The exchangeable cations $(\mathrm{Ba}, \mathrm{Ca}, \mathrm{K}, \mathrm{Mg}, \mathrm{Na}$, and $\mathrm{Sr}$ ) in the ammonium acetate extract were analyzed by ICP-OES. Cation concentrations were converted to milli-equivalent (meq) and summed to get the total CEC of the composite sediments (in meq/100 g). Our method is quite similar to the ammonium acetate method used to estimate exchangeable cations found in the ASA chapter written by Suarez (1996 pp. 583-584).

\subsubsection{Saturated Hydraulic Conductivity}

Saturated hydraulic conductivity measurements were made on 10 undisturbed core liners from borehole 299-E13-65 (C7047) using the falling-head method. A major advantage of the falling-head method over constant head and other methods is that it can be used for both fine-grained and coarsegrained soils, both of which are present at the BC Cribs site (Serne et al. 2009). For hydraulic measurements by falling-head test, each core liner was fitted with two machined Plexiglas ${ }^{\circledR}$ collars, one 
at each end, to allow attachment of end plates. Because some cores were not fully covered, sediment collected from adjacent cores was used to fill the empty space of the core. After the end plates were attached, the core was saturated and weighed. A small reservoir fill with water was used to saturate the cores with different saturation heights to minimize the air-entrapment during saturation. For these tests, a burette was used as the small-diameter reservoir and the saturated cores were connected to a burette through water-filled tubing. The burette was filled with water, and the height at time zero, $\mathrm{h}_{0}$, was recorded. The measurement was started by opening the burette stopcock, and the rate of decline of the water level in the burette was recorded over time. The hydraulic head at the upgradient end of the sample was allowed to decline from $h_{0}$, at time $0\left(t_{0}\right)$, to $h_{t}$ at some time $t\left(t_{t}\right)$. The calculation of $K_{s}$ is based on Darcy's Law, with $\mathrm{K}_{\mathrm{s}}$ being defined as follows:

$$
K_{s}=\left[\frac{a L_{c}}{A\left(t_{t}-t_{0}\right)}\right] \cdot \log \left(\frac{h_{0}}{h_{t}}\right)
$$

where $a$ is the cross-sectional area of the small reservoir, A is the cross-sectional area of the soil core, and $\mathrm{L}_{\mathrm{c}}$ is the length of the soil core.

Each measurement was repeated three times using different initial hydraulic gradients. A mean value of $\mathrm{K}_{\mathrm{s}}$ was then calculated for head gradient as the average of the three replicates. Owing to the nature and levels of contaminants in the cores, all work conducted on the cores was performed in a radiation control area.

\subsubsection{Air Permeability}

Air permeability is important to gas-transport studies and for remediation techniques that may involve the injection of gas-phase reactants and heated dehumidified air for desiccation at the BC Cribs and Trenches Area. Air permeability is relatively easy to measure and was measured on 10 undisturbed core liners from borehole 299-E13-65 (C7047) using an automated gas mini-permeameter (Tidwell and Wilson 1997). The mini-permeameter consists of four electronic mass-flow meters $\left(0 \mathrm{~cm}^{3} / \mathrm{min}\right.$ to $50 \mathrm{~cm}^{3} / \mathrm{min}$, $0 \mathrm{~cm}^{3} /$ min to $500 \mathrm{~cm}^{3} / \mathrm{min}, 0 \mathrm{~cm}^{3} / \min$ to $2000 \mathrm{~cm}^{3} / \mathrm{min}$, and $0 \mathrm{~cm}^{3} / \mathrm{min}$ to $20,000 \mathrm{~cm}^{3} / \mathrm{min}$ at standard conditions), a pressure transducer (0 to $100 \mathrm{kPa}$ gauge), a barometer, and a gas temperature sensor that are all connected to a regulated source of air, generated by an automated piston. Measurements were made by pressing a molded silicone rubber tip seal against the soil surface (both core ends) while injecting gas at a constant pressure. We used a tip seal with an inner radius of $0.31 \mathrm{~cm}$ and an outer radius measuring twice the inner diameter. An inner spring-driven guide and an immobile outer guide maintained consistent seal geometry under compressed conditions. The ring-shaped seal imposed a strongly divergent flow field resulting in a roughly hemispherical sample support (i.e., sample volume). Gas flow was directed into the soil via the tip seal affixed to a rigid brass housing (Tidwell and Wilson 1997).

Using information on the seal geometry, gas flow rate, gas injection pressure, and barometric pressure, the permeability was calculated using a modified form of Darcy's Law (Goggin et al. 1988):

$$
k_{a}=\frac{Q_{1} P_{1} \mu_{a}(T)}{0.5 r_{i} G_{0}\left(\frac{r_{0}}{r_{i}}\right)\left[P_{1}^{2}-P_{0}^{2}\right]}
$$


where:

$$
\begin{array}{ll}
\mathrm{k}_{\mathrm{a}} & \text { air permeability }\left(\mathrm{m}^{2}\right) \\
\mathrm{Q}_{1} & =\text { gas flow rate } \\
\mathrm{P}_{0} & =\text { fluid density, } \\
\mathrm{P}_{1} & \text { gas injection pressure } \\
\mu_{a}(T) & =\text { gas viscosity as a function of temperature } \mathrm{T} \\
\mathrm{G}_{0}\left(\mathrm{r}_{0} / \mathrm{r}_{\mathrm{i}}\right) & = \\
& \text { to geometric factor that varies according to the ratio of the outer tip seal radius } \mathrm{r}_{0}
\end{array}
$$

For the permeameter used for these measurements, $\mathrm{G}_{0}\left(\mathrm{r}_{0} / \mathrm{r}_{\mathrm{i}}\right)=\mathrm{G}_{0}(2)=5.03$. Vertical $\mathrm{k}_{\mathrm{a}}$ measurements were made on three randomly selected locations on each end of the intact sediment core, and the results were averaged to compute the mean vertical air permeability for each sample. An air-permeability value equivalent to the saturated hydraulic conductivity $(\mathrm{cm} / \mathrm{hr}$ ) can be calculated using Equation (2.7):

$$
K_{a}=\kappa_{a} \frac{\rho_{a} g}{\mu}
$$

where:
$K_{a}=$ pneumatic conductivity (cm/hour)
$\rho_{\mathrm{a}}=$ the representative particle diameter of the mixture
$\rho=$ density of air
$g=$ acceleration due to gravity
$\mu \quad=\quad$ dynamic viscosity of air. 


\subsection{Results and Discussion}

This section presents the geochemical and physical characterization data collected on sediments from borehole 299-E13-65 (C7047) that was recently placed adjacent to previous borehole 299-E13-62 (C5923) located directly south of the southeast corner of 216-B-17 Crib and directly west of the southwest corner of 216-B-16 Crib (Figure 1.1). Ten selected cores out of a total of 24 collected core sediment samples were used to characterize the hydraulic and geochemical properties of the sediment.

The characterization activities provided basic characterization information that is key to determining the vertical distribution of mobile contaminants and moisture and major solutes in the vadose zone pore water. Information about the borehole sediments presented in this section includes moisture content, $\mathrm{pH}$, and EC of 1:1 sediment-to-water extracts, and measurements of major cations, anions, and radionuclides in both the sediment and 1:1 sediment-to-water extracts. A GEA of selected core samples was also performed to search for any detectable manmade gamma-emitting radionuclides. The total chemical composition of selected sediment samples was measured by strong acid extracts. The PSD, surface area, CEC, saturated hydraulic conductivity, and air-permeability were measured for the selected cores samples to provide more data for predicting baseline risk and selecting appropriate remedial alternatives for final site cleanup. All of the photos of grab samples and core samples are provided in Appendix B.

\subsection{Moisture Content}

This section describes the results of moisture analysis performed on the sediment samples. The moisture profile of borehole sediments illustrates the relative distribution of moisture throughout the borehole. The gravimetric moisture contents of the sediment from the grab and core samples from 299E13-65 (C7047) is listed with geologic information in Table 3.1. The sample ID numbers are the sample unique HEIS numbers assigned by FHI staff. A summary of hydrogeologic logs including an integration of all the geologic, field geophysical neutron moisture logs, and laboratory measured moisture data collected for borehole C7047 is presented in Figure 3.1.

Table 3.1. Grab and Core Samples Collected from Borehole 299-E13-65 (C7047)

\begin{tabular}{llcllc}
\hline Type & HEIS \# & Mid-Depth (ft) & Lithology & Stratigraphic Unit & $\begin{array}{c}\text { Moisture } \\
\text { Content (\%) }\end{array}$ \\
\hline GRAB & B1YR86 & 9.75 & sand & Hanford formation H2 & 8.89 \\
GRAB & B1YR87 & 12.0 & gravelly sand & Hanford formation H2 & 4.51 \\
GRAB & B1YR86 & 9.75 & gravelly sand & Hanford formation H2 & 8.86 \\
GRAB & B1YR87 & 12.0 & gravelly sand & Hanford formation H2 & 4.51 \\
GRAB & B1YR88 & 15.0 & gravelly sand & Hanford formation H2 & 3.83 \\
GRAB & B1YR89 & 17.5 & gravelly sand & Hanford formation H2 & 5.06 \\
GRAB & B1YR90 & 20.0 & sand & Hanford formation H2 & 4.79 \\
GRAB & B1YR91 & 22.5 & gravelly silt sand & Hanford formation H2 & 10.1 \\
GRAB & B1YR92 & 25.0 & gravelly silt sand & Hanford formation H2 & 6.99 \\
GRAB & B1YR93 & 27.3 & gravelly silt sand & Hanford formation H2 & 7.91 \\
CORE & B1YRH3-2 & $\mathbf{2 9 . 0}$ & silty sand & Hanford formation H2 & 10.9 \\
CORE & B1YRH3-1 & $\mathbf{2 9 . 5}$ & silty sand & Hanford formation H2 & ND \\
GRAB & B1YR94 & 30.0 & silty sand & Hanford formation H2 & 8.97
\end{tabular}




\begin{tabular}{|c|c|c|c|c|c|}
\hline Type & HEIS \# & Mid-Depth (ft) & Lithology & Stratigraphic Unit & $\begin{array}{c}\text { Moisture } \\
\text { Content (\%) }\end{array}$ \\
\hline CORE & B1YRH4-2 & 30.8 & silty sand & Hanford formation $\mathrm{H} 2$ & 12.7 \\
\hline CORE & B1YRH4-1 & 31.3 & silty sand & Hanford formation $\mathrm{H} 2$ & ND \\
\hline GRAB & B1YR95 & 31.8 & silty sand & Hanford formation $\mathrm{H} 2$ & 9.84 \\
\hline CORE & B1YRH5-2 & 33.2 & silty sand & Hanford formation $\mathrm{H} 2$ & 9.67 \\
\hline CORE & B1YRH5-1 & 33.7 & silty sand & Hanford formation $\mathrm{H} 2$ & ND \\
\hline GRAB & B1YR96 & 34.2 & silty sand & Hanford formation $\mathrm{H} 2$ & 10.6 \\
\hline CORE & B1YRH6-2 & 36.7 & silty sand & Hanford formation $\mathrm{H} 2$ & 14.8 \\
\hline CORE & B1YRH6-1 & 37.2 & silty sand & Hanford formation $\mathrm{H} 2$ & ND \\
\hline GRAB & B1YR97 & 37.7 & silty sand & Hanford formation $\mathrm{H} 2$ & 11.7 \\
\hline CORE & B1YRH7-2 & 38.5 & silty sand & Hanford formation $\mathrm{H} 2$ & 9.67 \\
\hline CORE & B1YRH7-1 & 39.0 & silty sand & Hanford formation $\mathrm{H} 2$ & ND \\
\hline GRAB & B1YR98 & 39.5 & sandy silt & Hanford formation $\mathrm{H} 2$ & 12.0 \\
\hline CORE & B1YRH8-4 & 40.0 & sand & Hanford formation $\mathrm{H} 2$ & ND \\
\hline CORE & B1YRH8-2 & 41.0 & sand & Hanford formation $\mathrm{H} 2$ & 4.93 \\
\hline CORE & B1YRH9-3 & 40.5 & sand & Hanford formation $\mathrm{H} 2$ & ND \\
\hline CORE & B1YRH9-1 & 41.5 & sand & Hanford formation $\mathrm{H} 2$ & ND \\
\hline GRAB & B1YRB0 & 42.0 & sand & Hanford formation $\mathrm{H} 2$ & 3.91 \\
\hline CORE & B1YRJ0-2 & 43.7 & sand & Hanford formation $\mathrm{H} 2$ & ND \\
\hline CORE & B1YRJ0-1 & 44.2 & sand & Hanford formation $\mathrm{H} 2$ & ND \\
\hline GRAB & B1YRB1 & 44.7 & sand & Hanford formation $\mathrm{H} 2$ & 6.67 \\
\hline CORE & B1YRJ1-2 & 46.1 & sand & Hanford formation $\mathrm{H} 2$ & 3.89 \\
\hline CORE & B1YRJ1-1 & 46.6 & sand & Hanford formation $\mathrm{H} 2$ & ND \\
\hline GRAB & B1YRB2 & 47.1 & sand & Hanford formation $\mathrm{H} 2$ & 4.25 \\
\hline CORE & B1YRJ2-2 & 48.5 & sand & Hanford formation $\mathrm{H} 2$ & 3.34 \\
\hline CORE & B1YRJ2-1 & 49.0 & sand & Hanford formation $\mathrm{H} 2$ & ND \\
\hline GRAB & B1YRB3 & 49.5 & sand & Hanford formation $\mathrm{H} 2$ & 3.63 \\
\hline CORE & B1YRJ3-2 & 51.4 & sand & Hanford formation $\mathrm{H} 2$ & 2.70 \\
\hline CORE & B1YRJ3-1 & 51.9 & sand & Hanford formation $\mathrm{H} 2$ & ND \\
\hline GRAB & B1YRB4 & 52.4 & silty sand & Hanford formation $\mathrm{H} 2$ & 3.29 \\
\hline CORE & B1YRJ4-2 & 53.5 & silty sand & Hanford formation $\mathrm{H} 2$ & 2.75 \\
\hline CORE & B1YRJ4-1 & 54.0 & silty sand & Hanford formation $\mathrm{H} 2$ & ND \\
\hline GRAB & B1YRB5 & 56.0 & silty sand & Hanford formation $\mathrm{H} 2$ & 3.02 \\
\hline GRAB & B1YRB6 & 58.0 & silty sand & Hanford formation $\mathrm{H} 2$ & 2.84 \\
\hline GRAB & B1YRB7 & 60.0 & silty sand & Hanford formation $\mathrm{H} 2$ & 3.31 \\
\hline GRAB & B1YRB8 & 62.5 & silty sand & Hanford formation $\mathrm{H} 2$ & 2.43 \\
\hline GRAB & B1YRB9 & 65.5 & silty sand & Hanford formation $\mathrm{H} 2$ & 2.53 \\
\hline GRAB & B1YRC0 & 67.5 & silty sand & Hanford formation $\mathrm{H} 2$ & 2.69 \\
\hline GRAB & B1YRH2 & 70.0 & silty sand & Hanford formation $\mathrm{H} 2$ & 3.23 \\
\hline
\end{tabular}

A total of 35 grab and core sediment samples extending from the ground surface to $70 \mathrm{ft}$ below bgs were collected from borehole 299-E13-65 (C7047). The gravimetric moisture contents of the samples collected from C7047 varied from a low of $2.43 \mathrm{wt} \%$ to a high of $12.7 \mathrm{wt} \%$ (see Table 3.1). The average moisture content in the Hanford formation sediments located from $10 \mathrm{ft}$ to $70 \mathrm{ft}$ bgs is $6.4 \mathrm{wt} . \%$, which is consistent with the known range of moisture contents for uncontaminated Hanford formation vadose zone sediment. The only sediments with moisture contents equal to or greater than $7.0 \mathrm{wt} \%$ are found in the upper $40 \mathrm{ft}$ of the profile, especially between $20 \mathrm{ft}$ and $40 \mathrm{ft}$ bgs. The elevated moisture contents in these 
vadose zone sediment samples are likely from the fine-grained nature of the sediments and not residual waste fluids. As stated in a previous study of the borehole 299-E13-62 (C5923), the vadose zone beneath the BC Cribs and Trenches Area is dominated by a thick sand-dominated sequence of the Hanford formation (H2 unit). However, this sequence contains internally multiple beds of fine- to coarse-grained sand up to several meters thick that grade back and forth between coarse sand to fine sand multiple times before finally grading up into a silty fine sand to silt-textured cap (Serne et al. 2009). Due to a higher frequency of fine-grained, silty, slackwater beds in the upper part of the Hanford formation, these elevated moisture intervals are associated with Hanford formation stringers containing greater concentrations of silt and/or clay and posing higher moisture retention. These fine-grained silty beds are expected to increase the likelihood for lateral spreading of contaminant migration in the upper Hanford formation.

Because of the proximity of boreholes C7047 and C5923 to each other, their moisture contents are similar showing a narrow zone of relatively high moisture content in the upper $40 \mathrm{ft}$ to $45 \mathrm{ft}$ bgs and low moisture content less than $7 \mathrm{wt} \%$ at deeper depths (see Figure 3.1). Thicker and coarser flood beds are considered to be present in a deeper depth of the profile as evidenced by the lack of any zones with moisture contents greater than $7 \mathrm{wt} \%$ below $40 \mathrm{ft}$ bgs in C7047. Similar fine-grained silty beds are found in both $\mathrm{C} 7047$ and C5923 between $20 \mathrm{ft}$ and $40 \mathrm{ft}$ bgs. In comparison with C7047, where no high moisture was found at $16 \mathrm{ft}$ and $46 \mathrm{ft}$ bgs, borehole $\mathrm{C} 5923$ contains more thin zones with higher moisture in the upper $50 \mathrm{ft}$ of the Hanford formation (H2 unit) than borehole C7047. 


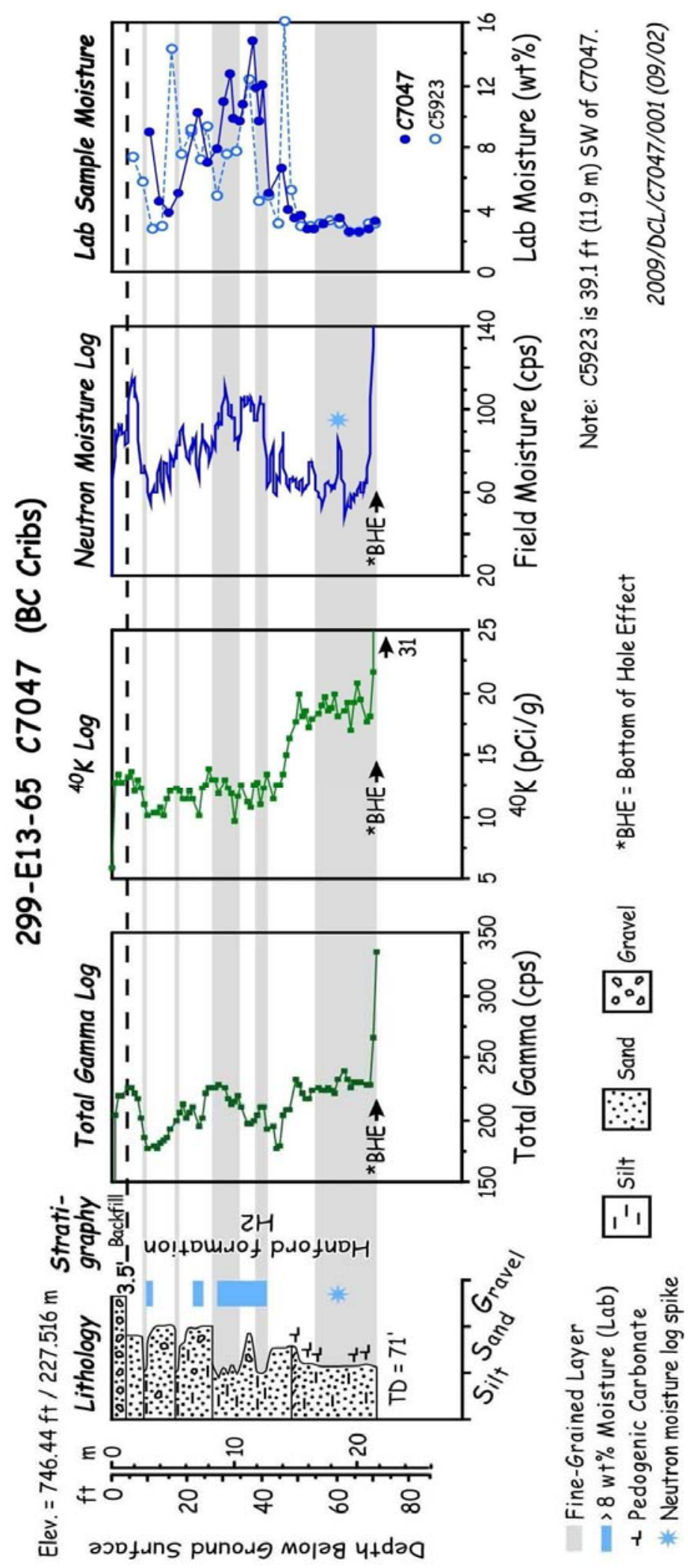

Figure 3.1. Composite Summary Log for Borehole C7047 with Laboratory Moisture from C5923 for Comparison 


\subsection{1:1 Sediment-to-Water Extracts}

Selected core and grab samples were processed by adding known amounts of DI water to aid in separating the native pore water in the relatively dry sediments. In this section, the water-extract data are reported in both units of pore water concentration and mass per gram of dry sediment for estimating vertical distribution of each species both in pore water and sediments, respectively.

\subsubsection{Water-Extract pH and Electrical Conductivity}

The $\mathrm{pH}$ and EC of water extracts are shown in Table 3.2. Figure 3.2 shows the $\mathrm{pH}$ measured in water extracts for both 299-E13-65 (C7047) and 299-E13-62 (C5923) boreholes. The measured pH for C7047 in water extracts ranges from $7.45 \mathrm{pH}$ to $9.65 \mathrm{pH}$. The $\mathrm{pH}$ of borehole $\mathrm{C} 7047$ show some samples above the depth of $53 \mathrm{ft}$ bgs with elevated $\mathrm{pH}$ values $(>8.5 \mathrm{pH})$ indicative of caustic waste contact. Similar high $\mathrm{pH}$ values of 9 to 10 are observed below and adjacent to single-shell tanks that have leaked highly caustic waste. The highest $\mathrm{pHs}(>9.0 \mathrm{pH})$ measured in water extracts of $\mathrm{C} 7047$ are found at the depths of $33 \mathrm{ft}$ to $40 \mathrm{ft}$ bgs where most fine-grained silty sand beds are located (see Table 3.1). Although the crib bottoms are considered approximately $11 \mathrm{ft}$ to $15 \mathrm{ft} \mathrm{bgs}$ at the time of their use, some of the shallow sediments in $\mathrm{C} 7047$ above $30 \mathrm{ft}$ bgs do not show any elevated $\mathrm{pH}(>9.0 \mathrm{pH})$. This condition is attributed to the $\mathrm{pH}$-buffer capacity of Hanford vadose zone sediments, which has buffered caustic waste plumes over the four to six decades since the fluids were released and sediments contaminated. High pHs found in the region of $33 \mathrm{ft}$ to $40 \mathrm{ft}$ bgs for C7047 indicate lateral spreading after downward movement of a leaking waste stream by the presence of fine-grained silty sand beds posing high water-retention capacity within micropores with capillary force. Below the depth of $40 \mathrm{ft}$ bgs of $\mathrm{C} 7047$, the $\mathrm{pH}$ gradually decreases with depths and reach the range of naturally occurring $\mathrm{pH}$ values $(7.0 \mathrm{pH}$ to $8.5 \mathrm{pH})$ in Hanford pore water below the depth of $55 \mathrm{ft}$ bgs.

The measured pHs of C7047 are very similar to those of C5923 at the shallow depths above $30 \mathrm{ft}$ bgs. The high $\mathrm{pH}$ (9.2) found at $8 \mathrm{ft}$ bgs of the $\mathrm{C} 5923$ borehole suggests that caustic waste must have ponded in the adjacent cribs and also migrated horizontally up to a few hundred feet (Serne et al. 2009).

Although there are no data for the $\mathrm{pH}$ measured in water extracts above $17 \mathrm{ft}$ bgs for $\mathrm{C} 7047$, based on the similar pHs measured in both $\mathrm{C} 7047$ and $\mathrm{C} 5923$ boreholes at between $17 \mathrm{ft}$ and $30 \mathrm{ft}$ bgs, a similar pH profile can be expected for $\mathrm{C} 7047$ at a shallow depth above $17 \mathrm{ft}$ bgs. The same trend of measured $\mathrm{pH}$ found in $\mathrm{C} 5923$ at deeper depths below $70 \mathrm{ft}$ bgs is also expected for C7047. The vertical extent of the elevated $\mathrm{pH}$ at borehole $\mathrm{C} 7047$, approximately between $33 \mathrm{ft}$ and $53 \mathrm{ft}$ bgs, is a bit larger than the thicknesses of impacted sediment observed at C5923. The thicker impact zone of elevated $\mathrm{pH}$ at borehole C7047 is considered to result from the location of C7047, which is much closer than C5923 to the nearby 216-B-16 and 216-B-17 cribs (see Figure 1.1). Because the C7047 borehole is closer to the cribs, more caustic wastes can contaminate sediments through lateral spreading after being disposed of in the cribs. 


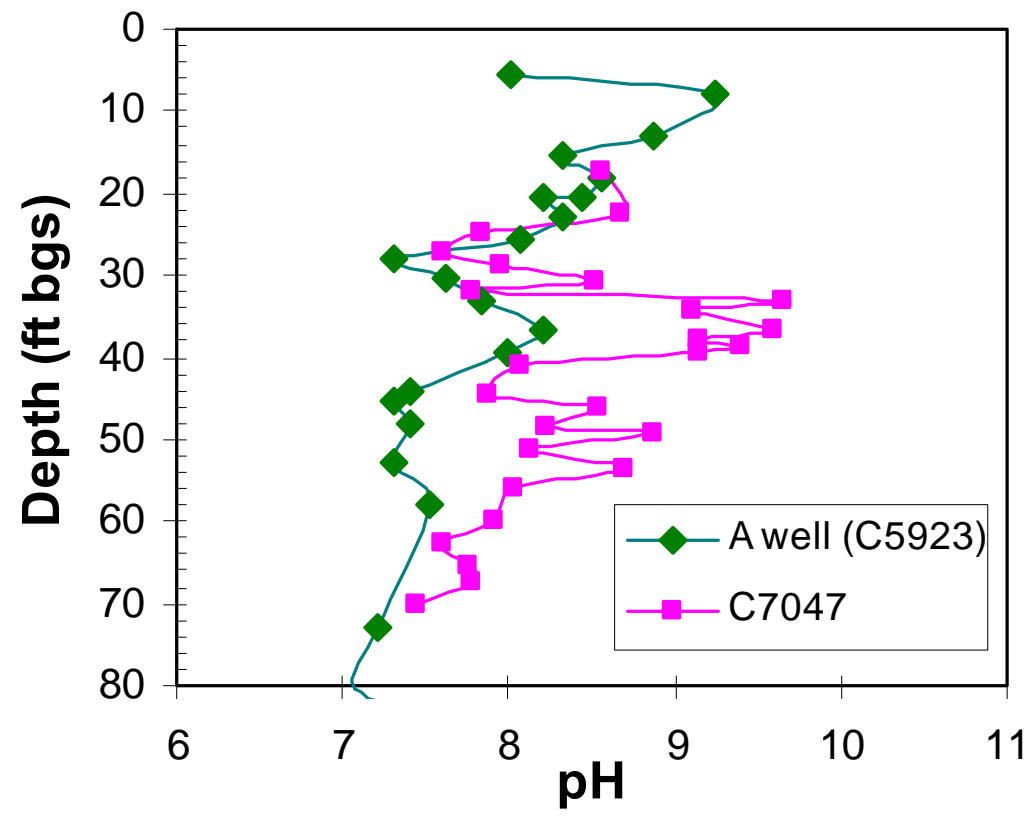

Figure 3.2. Measured pHs in Water Extracts for 299-E13-65 (C7047) Borehole Sediments

Table 3.2. $\mathrm{pH}$ and EC Values for 1:1 Sediment-to-Water Extracts from C7047

\begin{tabular}{lcccc}
\hline HEIS \# ID & $\begin{array}{c}\text { Mid Depth } \\
(\mathrm{ft}) \mathrm{bgs}\end{array}$ & $\begin{array}{c}1: 1 \text { Extract } \\
\mathrm{pH}\end{array}$ & $\begin{array}{c}1: 1 \text { Extract } \\
\text { Conductivity } \\
(\mathrm{mS} / \mathrm{cm})\end{array}$ & $\begin{array}{c}\text { Conductivity Dilution } \\
\text { Corrected in Pore Water } \\
(\mathrm{mS} / \mathrm{cm})\end{array}$ \\
\hline B1YR89 & 17.5 & 8.55 & 0.19 & 3.70 \\
B1YR91 & 22.5 & 8.68 & 1.11 & 11.1 \\
B1YR92 & 25.0 & 7.83 & 9.09 & 129.9 \\
B1YR93 & 27.3 & 7.60 & 8.75 & 113.6 \\
B1YRH3-2 & 29.0 & 7.95 & 12.5 & 128.2 \\
B1YRH4-2 & 30.8 & 8.52 & 9.91 & 77.8 \\
B1YR95 & 31.8 & 7.78 & 11.5 & 116.5 \\
B1YRH5-2 & 33.2 & 9.65 & 8.16 & 84.8 \\
B1YR96 & 34.2 & 9.10 & 5.85 & 55.2 \\
B1YRH6-2 & 36.7 & 9.60 & 7.66 & 51.8 \\
B1YR97 & 37.7 & 9.14 & 8.61 & 73.6 \\
B1YRH7-2 & 38.5 & 9.39 & 4.98 & 53.8 \\
B1YR98 & 39.5 & 9.15 & 7.98 & 66.5 \\
B1YRH8-2 & 41.0 & 8.07 & 5.94 & 120.7 \\
B1YRB1 & 44.7 & 7.87 & 12.3 & 181.9 \\
B1YRJ1-2 & 46.1 & 8.54 & 14.0 & 357.3 \\
B1YRJ2-2 & 48.5 & 8.23 & 15.3 & 455.6 \\
B1YRB3 & 49.5 & 8.88 & 10.7 & 296.1 \\
B1YRJ3-2 & 51.4 & 8.12 & 9.70 & 361.0 \\
\hline
\end{tabular}




\begin{tabular}{lcccc}
\hline HEIS \# ID & $\begin{array}{c}\text { Mid Depth } \\
(\mathrm{ft}) \mathrm{bgs}\end{array}$ & $\begin{array}{c}1: 1 \text { Extract } \\
\mathrm{pH}\end{array}$ & $\begin{array}{c}1: 1 \text { Extract } \\
\text { Conductivity } \\
(\mathrm{mS} / \mathrm{cm})\end{array}$ & $\begin{array}{c}\text { Conductivity Dilution } \\
\text { Corrected in Pore Water } \\
(\mathrm{mS} / \mathrm{cm})\end{array}$ \\
B1YRJ4-2 & 53.5 & 8.70 & 11.6 & 412.2 \\
B1YRB5 & 56.0 & 8.04 & 10.8 & 357.9 \\
B1YRB7 & 60.0 & 7.91 & 12.6 & 380.4 \\
B1YRB8 & 62.5 & 7.60 & 5.21 & 211.1 \\
B1YRB9 & 65.5 & 7.76 & 5.83 & 231.0 \\
B1YRC0 & 67.5 & 7.77 & 6.32 & 235.4 \\
B1YRH2 & 70.0 & 7.45 & 7.18 & 223.4 \\
\hline
\end{tabular}

The EC, total ionic strength, and major dissolved constituents of pore water are shown in Figure 3.3. The pore-water EC data for both C7047 and C5923 show a very similar distribution pattern at the shallow depth above $70 \mathrm{ft}$ bgs, except for the noticeable bimodal EC distribution between 25-35 ft and 46-61 ft bgs in C7047. Although the sediments from C5923 appear to show a trimodal peak in pore-water EC data extending up to $300 \mathrm{ft}$ bgs (Serne et al. 2009) with three EC maxima at $90 \mathrm{ft}, 132 \mathrm{ft}$, and $230 \mathrm{ft}$ bgs, porewater EC data at C7047 also show bimodal distribution, especially at the shallower depth above $70 \mathrm{ft}$ bgs (see Figure 3.3). The shallow lobe of high EC in C7047 is about 10-ft thick with maximum pore-water EC of $130 \mathrm{mS} / \mathrm{cm}$ at $25 \mathrm{ft}$ bgs, while the deep lobe is about $15-\mathrm{ft}$ thick with maximum pore-water EC of $456 \mathrm{mS} / \mathrm{cm}$ at $48.5 \mathrm{ft}$ bgs. The maximum EC values of C7047 in two lobes are much higher than those of C5923 at similar depths. The higher values of pore-water EC found in the lobes of C7047 than C5923 at shallow depth are also attributed to the large volume of wastes disposed of in the 216-B-16 and 216-B-17 cribs ( $\sim 9$ million liters) and the location of C7047 being much closer to those cribs than C5923. Even though data are limited for the depths below $70 \mathrm{ft}$ bgs in C7047, deeper penetration of salt and wastes is also expected in borehole $\mathrm{C} 7047$ based on a comparison of what with pore-water EC data of C5923 extending to $350 \mathrm{ft}$ bgs (Serne et al. 2009). 


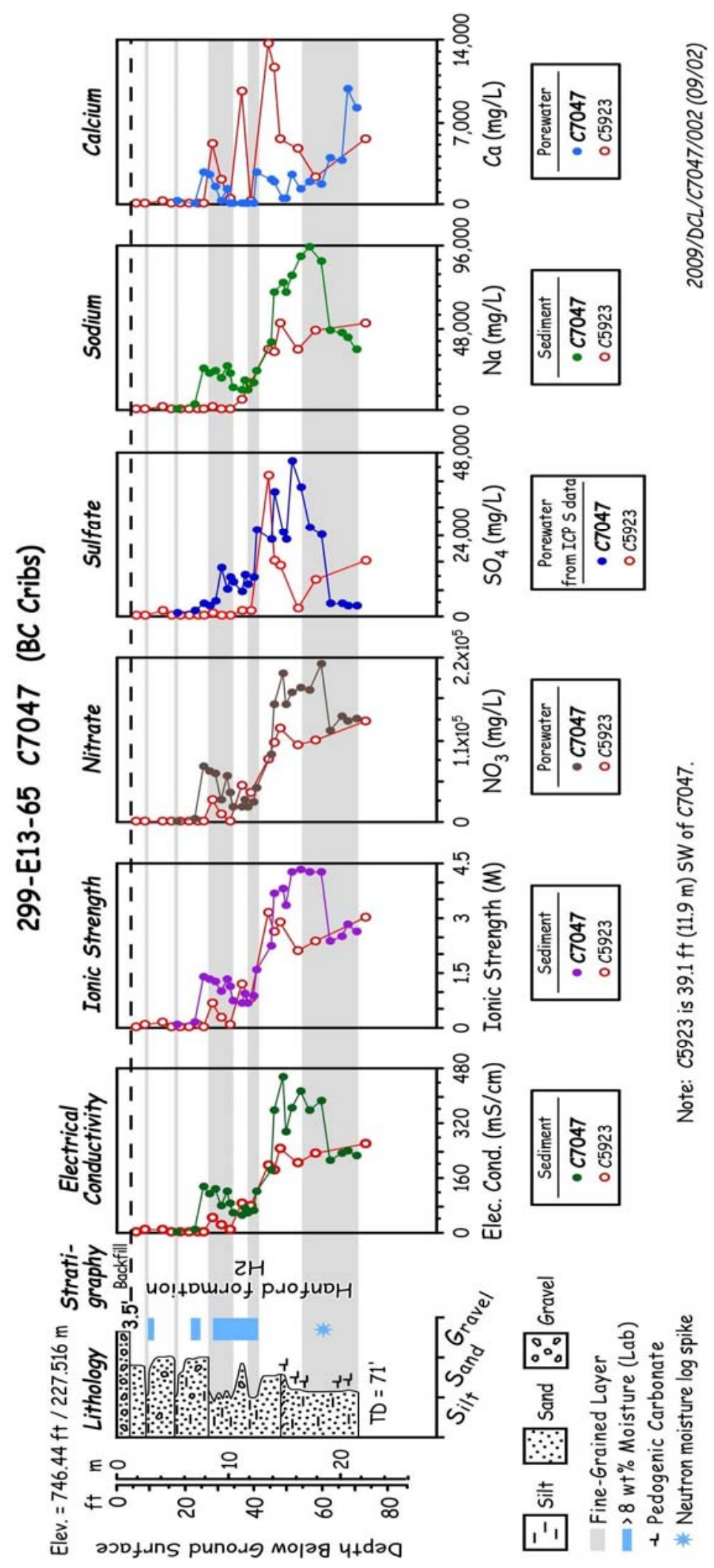

Figure 3.3. Pore-Water EC, Ionic Strength and Major Ions in Borehole 299-E13-65 (C7047) with Comparison of C5923 


\subsubsection{Water Extract Composition for C7047}

The 1:1 sediment-to-water extract anion composition, in units of micrograms per gram $(\mu \mathrm{g} / \mathrm{g})$ of dry sediment and in units of milligrams per liter $(\mathrm{mg} / \mathrm{L})$ of the calculated pore water, are shown in Table 3.3 and Table 3.4, respectively. Figure 3.3 shows the calculated pore-water concentrations of nitrate and sulfate, which are the most dominant anions in water extracts. Because of a tri-butylphosphate-based process used to recover uranium from bismuth phosphate wastes retrieved from single-shell tanks, about 2.67 metric tons of dissolved salts consisting mainly of nitrate and sodium (combined, these represent 2.39 metric tons) and lesser amounts of sulfate, phosphate, fluoride, chloride, and potassium were disposed of into the 216-B-16 and 216-B-17 cribs (Serne et al. 2009). More details about the waste composition can be found in Corbin et al. (2005) and the appendixes to the Data Quality Objectives report (Benecke 2008).

The vadose zone sediments in borehole C7047 show elevated concentrations of most of the aforementioned anions except fluoride and nitrite. Because of the reactive anions, phosphate and carbonate are immobilized between $30 \mathrm{ft}$ and $40 \mathrm{ft}$ bgs where fine-grained silty sand beds are found. Elevated $\mathrm{pH}$ and moisture content in water extracts previously confirmed waste contact with fine-grained silty sand beds at this range of depths. Elevated sulfate concentrations are found in one broad region of the $\mathrm{C} 7047$ from $30 \mathrm{ft}$ to $60 \mathrm{ft}$ bgs. The highest peak of chloride concentration is found at $29 \mathrm{ft}$ bgs and decreases with depth below $29 \mathrm{ft}$ bgs. Figure 3.4 plots the nitrate concentration per gram of dry sediment as a function of depth. The most elevated nitrate concentration is also found at the same depth as the highest concentrations of chloride and sulfate are found, $29 \mathrm{ft}$ bgs. The second-highest peak of nitrate concentration is found at the depth of $49 \mathrm{ft}$ bgs in $\mathrm{C} 7047$ close to the highest peak of nitrate concentration $(16,773 \mu \mathrm{g} / \mathrm{g})$ found in a water extract sample of the $\mathrm{C} 5923$ borehole at $46 \mathrm{ft}$ bgs. The third-highest peak of nitrate concentration found in $\mathrm{C} 4074$ is a little bit deep at $60 \mathrm{ft}$ bgs. The massive quantity of disposed nitrate makes it a good tracer of the waste-fluid plume location because of the mobile behavior of nitrate with no reaction on the surrounding sediments. The depth distributions do not show any vertical differences between sulfate, chloride, and nitrate, which suggests that the contamination at borehole C7047 has migrated into the region via horizontal flow. The lack of vertical discrimination of anions for sulfate and nitrate is also reported in nearby borehole C5923 (Serne et al. 2009). 


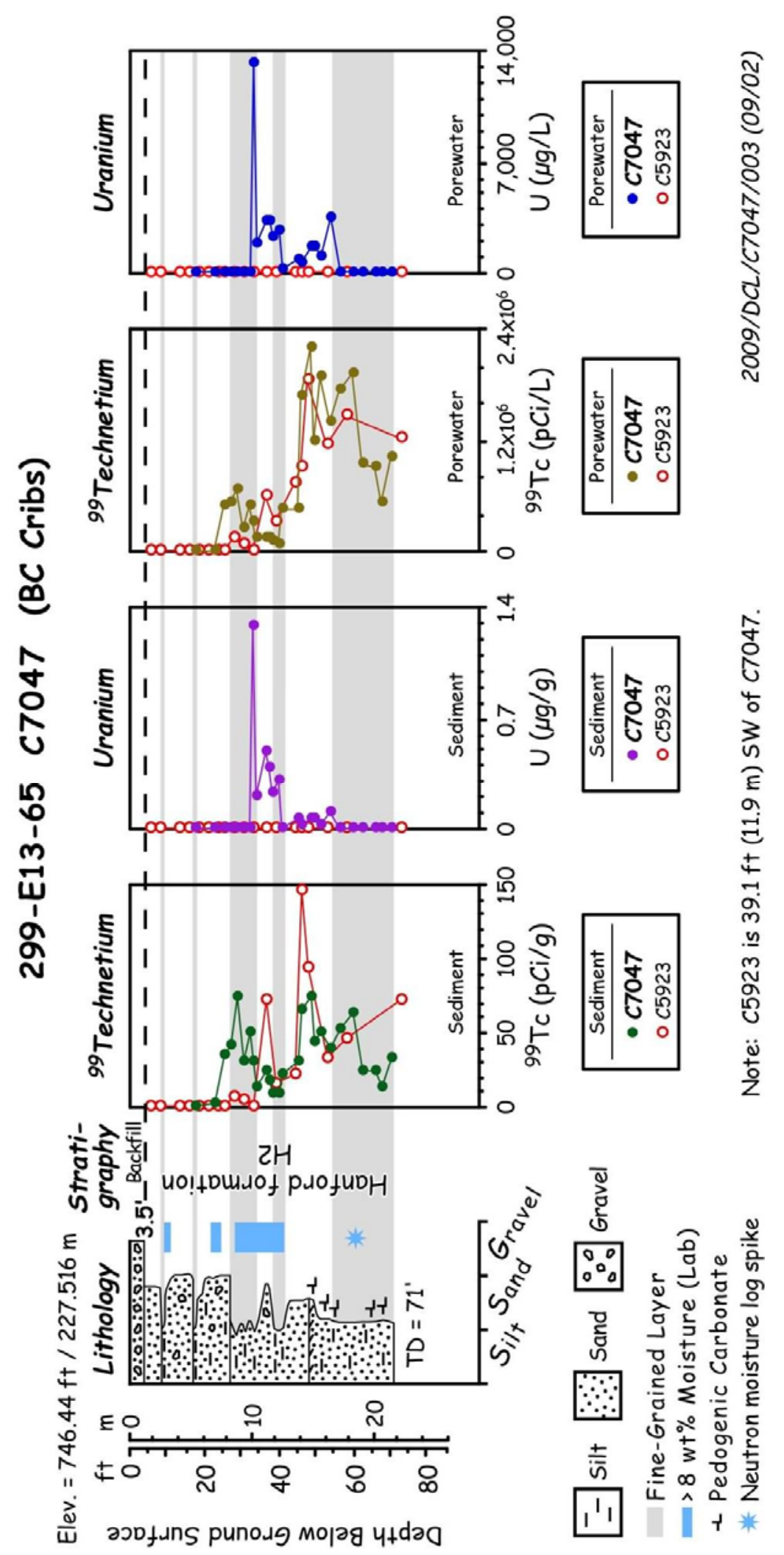

Figure 3.4. Water-Extractable Technetium-99 and Uranium-238 in Sediments from Borehole C7047 in Comparison to C5923 
Table 3.3. Anion Composition of Water Extracts of C7047 ( $\mu \mathrm{g} / \mathrm{g}$ dry sediment)

\begin{tabular}{lcccccccc}
\hline \multicolumn{1}{c}{ Sample ID } & $\begin{array}{c}\text { Mid } \\
\text { Depth } \\
\text { (ft bgs) }\end{array}$ & Fluoride & Chloride & Nitrite & Nitrate & Sulfate-IC & Phosphate-IC & $\begin{array}{c}\text { Alkalinity } \\
\text { (as CaCO }\end{array}$ \\
\hline B1YR89 & 17.5 & 0.86 & 5.98 & $<1.0$ & 7.38 & 20.7 & 0.240 & 61.7 \\
B1YR91 & 22.5 & 1.47 & 45.8 & $<1.0$ & 301 & 108 & $<1.5$ & 159 \\
B1YR92 & 25.0 & $<0.2$ & 85.0 & 8.19 & 5102 & 180 & 5.09 & 51.1 \\
B1YR93 & 27.3 & 6.45 & 82.7 & 8.00 & 5359 & 189 & $<1.5$ & 53.3 \\
B1YRH3-2 & 29.0 & $<0.2$ & 101 & 9.76 & 7125 & 413 & $<1.5$ & 57.5 \\
B1YRH4-2 & 30.8 & $<0.2$ & 84.2 & 7.98 & 3760 & 1728 & $<1.5$ & 102 \\
B1YR95 & 31.8 & $<0.2$ & 92.8 & $<1.0$ & 6122 & 632 & $<1.5$ & 62.0 \\
B1YRH5-2 & 33.2 & $<0.2$ & 75.0 & 8.84 & 3594 & 979 & 106 & 410 \\
B1YR96 & 34.2 & 2.74 & 52.0 & $<1.0$ & 2150 & 1014 & 54.6 & 243 \\
B1YRH6-2 & 36.7 & $<0.2$ & 76.6 & 6.91 & 2647 & 939 & 132 & 579 \\
B1YR97 & 37.7 & 4.23 & 73.1 & $<1.0$ & 3457 & 1280 & 62.1 & 342 \\
B1YRH7-2 & 38.5 & $<0.2$ & 56.9 & 8.14 & 1777 & 831 & 15.6 & 202 \\
B1YR98 & 39.5 & 3.88 & 71.7 & 10.4 & 2958 & 1275 & 33.7 & 316 \\
B1YRH8-2 & 41.0 & $<0.2$ & 51.9 & 6.81 & 2184 & 1242 & 5.21 & 39.8 \\
B1YRB1 & 44.7 & $<0.2$ & 76.1 & $<1.0$ & 5940 & 1430 & 8.01 & 59.7 \\
B1YRJ1-2 & 46.1 & $<0.2$ & 45.3 & 9.53 & 6059 & 1338 & 6.45 & 50.1 \\
B1YRJ2-2 & 48.5 & $<0.2$ & 60.4 & 10.4 & 6640 & 1577 & 7.29 & 34.3 \\
B1YRB3 & 49.5 & $<0.2$ & 50.3 & $<1.0$ & 5675 & 734 & 13.4 & 106 \\
B1YRJ3-2 & 51.4 & $<0.2$ & 34.7 & 8.84 & 4664 & 1197 & 5.12 & 30.7 \\
B1YRJ4-2 & 53.5 & $<0.2$ & 39.5 & 8.80 & 4951 & 1016 & $<1.5$ & 51.5 \\
B1YRB5 & 56.0 & $<0.2$ & 44.0 & $<1.0$ & 5294 & 1002 & $<1.5$ & 54.2 \\
B1YRB7 & 60.0 & $<0.2$ & 52.2 & $<1.0$ & 6952 & 718 & $<1.5$ & 49.5 \\
B1YRB8 & 62.5 & $<0.2$ & 29.4 & 5.82 & 2980 & 46.6 & $<1.5$ & 22.6 \\
B1YRB9 & 65.5 & 3.13 & 25.0 & $<1.0$ & 3553 & 61.2 & $<1.5$ & 39.8 \\
B1YRC0 & 67.5 & $<0.2$ & 29.6 & $<1.0$ & 3575 & 78.3 & $<1.5$ & 32.1 \\
B1YRH2 & 70.0 & 4.50 & 33.0 & $<1.0$ & 4390 & 58.1 & $<1.5$ & 39.9 \\
\hline <values = below level of quantitation. & & & & & & \\
\hline & & & & & & & & \\
\hline
\end{tabular}

Table 3.4 shows the same water-extract anion data in units of $\mathrm{mg} / \mathrm{L}$ in pore-water concentrations. Some dominant pore-water anion and cation concentrations can be found in Figure 3.3. The highest concentration of pore-water nitrate $(209,881 \mathrm{mg} / \mathrm{L})$ is found at $60 \mathrm{ft}$ bgs and is indicative of downward movement of the nitrate-containing waste plume. The highest pore-water concentration of chloride is found at the same depth as nitrate at $60 \mathrm{ft}$ bgs. Pore-water concentrations of sulfate and phosphate were analyzed using both IC and ICP-OES, and comparison of the results from different methods shows pretty good. However, because ICP-OES has less interference by coexisting ions in sample analysis, ICP-OES results are used for determining the total ionic strength in pore water. 
Table 3.4. Water-Extractable Anions Converted to Pore-Water Concentrations for C7047 Borehole Samples $(\mathrm{mg} / \mathrm{L})$

\begin{tabular}{|c|c|c|c|c|c|c|c|c|c|c|}
\hline HEIS \# & $\begin{array}{c}\text { Mid } \\
\text { Depth } \\
\text { (ft bgs) } \\
\end{array}$ & Fluoride & Chloride & Nitrite & Nitrate & Sulfate-IC & $\begin{array}{l}\text { Sulfate- } \\
\text { ICP-OES }\end{array}$ & $\begin{array}{l}\text { Phosphate- } \\
\text { IC }\end{array}$ & $\begin{array}{c}\text { Phosphate- } \\
\text { ICP-OES }\end{array}$ & $\begin{array}{c}\text { Alkalinity } \\
\text { (as } \\
\left.\mathrm{CaCO}_{3}\right)\end{array}$ \\
\hline B1YR89 & 17.5 & 17.0 & 118.1 & $<1.0$ & 146 & 409 & 437 & 4.8 & 9.15 & 1220 \\
\hline B1YR91 & 22.5 & 14.6 & 453.7 & $<1.0$ & 2989 & 1067 & 1170 & $<1.5$ & 8.35 & 1577 \\
\hline B1YR92 & 25.0 & $<0.2$ & 1216 & 117.2 & 73025 & 2579 & 3310 & 72.9 & 13.8 & 731 \\
\hline B1YR93 & 27.3 & 81.5 & 1045 & 101.2 & 67774 & 2389 & 3094 & 8.6 & 13.5 & 675 \\
\hline B1YRH3-2 & 29.0 & $<0.2$ & 928.8 & 89.6 & 65365 & 3787 & 4471 & $<1.5$ & 12.8 & 527 \\
\hline B1YRH4-2 & 30.8 & $<0.2$ & 662.6 & 62.8 & 29602 & 13603 & 14153 & $<1.5$ & 5.41 & 804 \\
\hline B1YR95 & 31.8 & $<0.2$ & 942.9 & $<1.0$ & 62181 & 6423 & 7505 & $<1.5$ & 12.4 & 629 \\
\hline B1YRH5-2 & 33.2 & $<0.2$ & 775.4 & 91.5 & 37165 & 10127 & 10914 & 1099 & 1109 & 4240 \\
\hline B1YR96 & 34.2 & 25.7 & 488.8 & $<1.0$ & 20215 & 9534 & 10012 & 513.7 & 550.0 & 2282 \\
\hline B1YRH6-2 & 36.7 & $<0.2$ & 517.7 & 46.7 & 17887 & 6346 & 6778 & 894.6 & 968.7 & 3909 \\
\hline B1YR97 & 37.7 & 36.1 & 623.3 & $<1.0$ & 29470 & 10916 & 11612 & 529.2 & 604.7 & 2915 \\
\hline B1YRH7-2 & 38.5 & $<0.2$ & 588.4 & 84.2 & 18375 & 8591 & 8858 & 160.9 & 139.6 & 2087 \\
\hline B1YR98 & 39.5 & 32.3 & 598.0 & 86.9 & 24672 & 10636 & 11336 & 281.4 & 324.2 & 2637 \\
\hline B1YRH8-2 & 41.0 & $<0.2$ & 1053 & 138.2 & 44303 & 25185 & 25185 & 105.7 & 19.7 & 808 \\
\hline B1YRB1 & 44.7 & $<0.2$ & 1141 & $<1.0$ & 89097 & 21445 & 22147 & 120.2 & 21.2 & 896 \\
\hline B1YRJ1-2 & 46.1 & $<0.2$ & 1164 & 245.0 & 155747 & 34385 & 36542 & 165.9 & 74.8 & 1287 \\
\hline B1YRJ2-2 & 48.5 & $<0.2$ & 1808 & 310.8 & 198812 & 47221 & 24179 & 218.1 & 306.1 & 1027 \\
\hline B1YRB3 & 49.5 & $<0.2$ & 1387 & $<1.0$ & 156492 & 20252 & 22311 & 369.5 & 282.5 & 2928 \\
\hline B1YRJ3-2 & 51.4 & $<0.2$ & 1284 & 327.4 & 172747 & 44321 & 45310 & 189.8 & 28.4 & 1137 \\
\hline B1YRJ4-2 & 53.5 & $<0.2$ & 1436 & 319.8 & 180032 & 36957 & 37633 & $<1.5$ & 16.9 & 1873 \\
\hline B1YRB5 & 56.0 & $<0.2$ & 1457 & $<1.0$ & 175474 & 33210 & 25875 & $<1.5$ & 31.5 & 1796 \\
\hline B1YRB7 & 60.0 & $<0.2$ & 1575 & $<1.0$ & 209881 & 21671 & 23537 & $<1.5$ & 28.6 & 1496 \\
\hline B1YRB8 & 62.5 & $<0.2$ & 1208 & 239.1 & 122520 & 1917 & 3364 & $<1.5$ & 23.7 & 929 \\
\hline B1YRB9 & 65.5 & 123.6 & 987.3 & $<1.0$ & 140386 & 2418 & 3288 & $<1.5$ & 23.2 & 1574 \\
\hline B1YRC0 & 67.5 & $<0.2$ & 1102 & $<1.0$ & 133030 & 2912 & 3180 & $<1.5$ & 31.2 & 1195 \\
\hline B1YRH2 & 70.0 & 139.4 & 1021 & $<1.0$ & 136075 & 1801 & 2657 & $<1.5$ & 26.0 & 1236 \\
\hline
\end{tabular}

Table 3.5 shows the water-leachable concentrations of divalent and monovalent cations, in units of $\mu \mathrm{g}$ per gram of dry sediment analyzed from borehole C7047. The most dominantly elevated concentration of cation is sodium. Figure 3.4 shows no difference in the vertical distribution of the major anion (nitrate), and the major cation (sodium) suggesting that $\mathrm{NaNO}_{3}$, which is a major constituent in waste plume, contacted the $\mathrm{C} 7047$ borehole sediments. At borehole C7047, the water-extractable Na shows elevated values over two shallow zones, one from $25 \mathrm{ft}$ to $40 \mathrm{ft}$ bgs and another from $45 \mathrm{ft}$ to $60 \mathrm{ft}$ bgs with three discrete maxima concentrations at $29 \mathrm{ft}, 49 \mathrm{ft}$, and $60 \mathrm{ft}$ bgs. Table 3.5 also shows the ion-exchange front that occurs when sodium-dominated liquid wastes are disposed of into native Hanford sediments that have their cation exchange surface sites naturally loaded with divalent cations, such as calcium, magnesium, 
and strontium. When waste liquid percolates below cribs both vertically and horizontally into a sediment profile, the sodium in the waste plume replaces the native divalent cations (and to some extent native potassium) present on the exchange sites and pushes the replaced divalent cations out in the leading edge of the waste plume (Serne et al. 2009). Table 3.5 shows depleted divalent cations over the depth range of $25 \mathrm{ft}$ to $60 \mathrm{ft}$ bgs where a high concentration of nitrate was found.

Table 3.5. Water Extractable Cations in Borehole C7047 Sediments ( $\mu \mathrm{g} / \mathrm{g}$ dry soil)

\begin{tabular}{lcccccc}
\hline \multicolumn{1}{c}{ HEIS \# } & $\begin{array}{c}\text { Mid Depth } \\
(\mathrm{ft} \text { bgs })\end{array}$ & $\begin{array}{c}\mathrm{Ca} \\
(\mu \mathrm{g} / \mathrm{g} \text { soil })\end{array}$ & $\begin{array}{c}\mathrm{Mg} \\
(\mu \mathrm{g} / \mathrm{g} \text { soil })\end{array}$ & $\begin{array}{c}\mathrm{Sr} \\
(\mu \mathrm{g} / \mathrm{g} \text { soil })\end{array}$ & $\begin{array}{c}\mathrm{Na} \\
(\mu \mathrm{g} / \mathrm{g} \text { soil })\end{array}$ & $\begin{array}{c}\mathrm{K} \\
(\mu \mathrm{g} / \mathrm{g} \text { soil })\end{array}$ \\
\hline B1YR89 & 17.5 & 7.64 & 1.73 & 0.040 & 27.2 & 5.34 \\
B1YR91 & 22.5 & 2.12 & 0.63 & 0.008 & 246.3 & 4.18 \\
\hline B1YR92 & 25.0 & 188.0 & 45.1 & 0.850 & 1626 & 36.8 \\
B1YR93 & 27.3 & 186.5 & 43.8 & 0.805 & 1700 & 36.8 \\
\hline B1YRH3-2 & 29.0 & 155.8 & 46.0 & 0.859 & 2505 & 40.8 \\
B1YRH4-2 & 30.8 & 21.1 & 10.3 & 0.123 & 2242 & 23.5 \\
B1YR95 & 31.8 & 125.5 & 36.7 & 0.620 & 2431 & 37.4 \\
B1YRH5-2 & 33.2 & 1.88 & 0.44 & 0.011 & 1964 & 11.1 \\
B1YR96 & 34.2 & 3.82 & 0.86 & 0.015 & 1334 & 9.82 \\
B1YRH6-2 & 36.7 & 1.74 & 0.18 & 0.010 & 1701 & 9.56 \\
B1YR97 & 37.7 & 3.66 & 0.89 & 0.018 & 1975 & 12.9 \\
B1YRH7-2 & 38.5 & 3.18 & 0.44 & 0.017 & 1124 & 8.69 \\
B1YR98 & 39.5 & 4.69 & 0.84 & 0.020 & 1869 & 12.9 \\
B1YRH8-2 & 41.0 & 133.0 & 17.7 & 0.411 & 1125 & 20.3 \\
B1YRB1 & 44.7 & 142.8 & 19.5 & 0.499 & 2642 & 29.1 \\
B1YRJ1-2 & 46.1 & 73.6 & 5.14 & 0.255 & 2637 & 18.4 \\
B1YRJ2-2 & 48.5 & 120.1 & 2.05 & 0.215 & 2913 & 22.9 \\
B1YRB3 & 49.5 & 12.2 & 3.08 & 0.097 & 2479 & 18.1 \\
\hline B1YRJ3-2 & 51.4 & 63.8 & 5.20 & 0.309 & 2106 & 19.3 \\
B1YRJ4-2 & 53.5 & 39.4 & 6.59 & 0.328 & 2142 & 29.3 \\
\hline B1YRB5 & 56.0 & 37.0 & 9.93 & 0.328 & 2502 & 25.7 \\
B1YRB7 & 60.0 & 55.5 & 19.7 & 0.511 & 2839 & 33.9 \\
\hline B1YRB8 & 62.5 & 231.3 & 49.9 & 1.886 & 723.6 & 20.0 \\
\hline B1YRB9 & 65.5 & 93.5 & 25.6 & 0.978 & 1130 & 25.6 \\
B1YRC0 & 67.5 & 112.8 & 37.1 & 1.032 & 1123 & 25.9 \\
B1YRH2 & 70.0 & 261.7 & 85.3 & 1.988 & 1116 & 35.6 \\
\hline
\end{tabular}

Table 3.6 shows the same water-leachable cation data in units of $\mathrm{mg} / \mathrm{L}$ of pore water assuming that adding DI water to field-moist sediment does not significantly dissolve solids and minerals; rather, it only dilutes and promotes the separation of the extant small volume of pore fluid. For highly contaminated vadose zone pore water, this assumption is fairly valid, but for slightly or uncontaminated pore water, the DI water still can dissolve some mildly soluble salts and carbonate coatings so that it can over-estimate the true pore-water concentrations. Figure 3.3 shows the calculated EC and ionic strength for the pore 
water in sediments from borehole $\mathrm{C} 7047$ plotted to show a qualitative representation of the shapes of the depth distributions of these parameters in water extracts.

Table 3.6. Water-Extractable Cations as Pore-Water Concentrations in Borehole C7047 Sediments $(\mathrm{mg} / \mathrm{L})$

\begin{tabular}{lcccccc}
\hline \multicolumn{1}{c}{ HEIS \# } & $\begin{array}{c}\text { Mid Depth } \\
(\mathrm{ft} b \mathrm{sg})\end{array}$ & $\begin{array}{c}\mathrm{Ca} \\
(\mathrm{mg} / \mathrm{L})\end{array}$ & $\begin{array}{c}\mathrm{Mg} \\
(\mathrm{mg} / \mathrm{L})\end{array}$ & $\begin{array}{c}\mathrm{Sr} \\
(\mathrm{mg} / \mathrm{L})\end{array}$ & $\begin{array}{c}\mathrm{Na} \\
(\mathrm{mg} / \mathrm{L})\end{array}$ & $\begin{array}{c}\mathrm{K} \\
(\mathrm{mg} / \mathrm{L})\end{array}$ \\
\hline B1YR89 & 17.5 & 150.9 & 34.2 & 0.785 & 536.8 & 105.5 \\
B1YR91 & 22.5 & 21.0 & 6.26 & 0.081 & 2439 & 41.4 \\
B1YR92 & 25.0 & 2691 & 645.0 & 12.2 & 23275 & 526.7 \\
B1YR93 & 27.3 & 2358 & 553.3 & 10.2 & 21495 & 465.6 \\
\hline B1YRH3-2 & 29.0 & 1429 & 421.9 & 7.88 & 22979 & 374.7 \\
B1YRH4-2 & 30.8 & 166.0 & 81.1 & 0.967 & 17651 & 184.7 \\
B1YR95 & 31.8 & 1274 & 372.5 & 6.29 & 24689 & 380.1 \\
B1YRH5-2 & 33.2 & 19.4 & 4.60 & 0.119 & 20314 & 114.5 \\
B1YR96 & 34.2 & 35.9 & 8.12 & 0.145 & 12547 & 92.3 \\
B1YRH6-2 & 36.7 & 11.8 & 1.21 & 0.065 & 11490 & 64.6 \\
\hline B1YR97 & 37.7 & 31.2 & 7.58 & 0.156 & 16837 & 110.2 \\
B1YRH7-2 & 38.5 & 32.9 & 4.55 & 0.176 & 11622 & 89.9 \\
B1YR98 & 39.5 & 39.1 & 7.00 & 0.164 & 15588 & 107.8 \\
B1YRH8-2 & 41.0 & 2697 & 358.1 & 8.33 & 22811 & 411.7 \\
B1YRB1 & 44.7 & 2143 & 291.9 & 7.48 & 39637 & 435.9 \\
B1YRJ1-2 & 46.1 & 1891 & 132.1 & 6.55 & 67790 & 473.0 \\
\hline B1YRJ2-2 & 48.5 & 366.0 & 91.9 & 2.91 & 74098 & 542.0 \\
B1YRB3 & 49.5 & 337.7 & 84.8 & 2.68 & 68373 & 500.1 \\
\hline B1YRJ3-2 & 51.4 & 2362 & 192.7 & 11.4 & 77989 & 713.8 \\
B1YRJ4-2 & 53.5 & 1316 & 353.2 & 11.7 & 88993 & 914.5 \\
\hline B1YRB5 & 56.0 & 1841 & 654.5 & 17.0 & 94227 & 1126 \\
B1YRB7 & 60.0 & 1674 & 595.3 & 15.4 & 85713 & 1024 \\
\hline B1YRB8 & 62.5 & 3779 & 1034 & 39.5 & 45680 & 1034 \\
\hline B1YRB9 & 65.5 & 3694 & 1010 & 38.6 & 44657 & 1011 \\
\hline B1YRC0 & 67.5 & 9709 & 3163 & 73.8 & 41396 & 1321 \\
B1YRH2 & 70.0 & 8114 & 2643 & 61.6 & 34597 & 1104 \\
\hline
\end{tabular}

As part of the characterization of the water extracts, other chemical species such as aluminum, silicon, iron, manganese, zinc, and trace constituents, such as arsenic, boron, barium, beryllium, bismuth, cadmium, cobalt, chromium, copper, lithium, molybdenum, nickel, lead, selenium, thallium, vanadium, titanium, and zirconium, were also measured. However, because their concentrations were generally low to nondetectable, the data are not presented in this document.

Table 3.7 and Figure 3.3 show the total ionic strengths of the calculated pore waters in the vadose zone profile at $\mathrm{C} 7047$ based on the measured pore-water concentrations of major cations and anions. Of all the pore-water parameters, the total ionic strength should correlate best with the total dissolved salt 
content in pore water, namely the major cation (sodium) and anion (nitrate) concentrations. A qualitative view of the distribution of ionic strength shows very similar distributions to pore-water concentrations of sodium and nitrate as well as EC data. The ionic strengths of borehole C7047 have two peaks of $1.4 \mathrm{M}$ and 4.3 $\mathrm{M}$ in the region of $25-35 \mathrm{ft}$ and $45-62 \mathrm{ft}$ bgs, respectively.

Table 3.7. Water-Extractable Radionuclides and Pore-Water Total Ionic Strength for C7047 Sediments

\begin{tabular}{|c|c|c|c|c|c|c|}
\hline HEIS \# & $\begin{array}{l}\text { Mid Depth } \\
\text { (ft bgs) }\end{array}$ & $\begin{array}{c}{ }^{99} \mathrm{Tc} \\
(\mathrm{pCi} / \mathrm{g})\end{array}$ & $\begin{array}{c}\mathrm{U} \\
(\mu \mathrm{g} / \mathrm{g})\end{array}$ & $\begin{array}{c}{ }^{99} \mathrm{Tc} \\
(\mathrm{pCi} / / \mathrm{L})\end{array}$ & $\begin{array}{c}\mathrm{U} \\
(\mu \mathrm{g} / \mathrm{L})\end{array}$ & $\begin{array}{c}\text { PW Ionic } \\
\text { Strength } \\
(\mathrm{M})\end{array}$ \\
\hline B1YR89 & 17.5 & $3.76 \mathrm{E}-02$ & $2.13 \mathrm{E}-03$ & $7.44 \mathrm{E}+02$ & $4.21 \mathrm{E}+01$ & $6.04 \mathrm{E}-02$ \\
\hline B1YR91 & 22.5 & $1.52 \mathrm{E}+00$ & $1.02 \mathrm{E}-02$ & $1.50 \mathrm{E}+04$ & $1.01 \mathrm{E}+02$ & $1.42 \mathrm{E}-01$ \\
\hline B1YR92 & 25.0 & $3.50 \mathrm{E}+01$ & $1.42 \mathrm{E}-03$ & $5.01 \mathrm{E}+05$ & $2.04 \mathrm{E}+01$ & $1.39 \mathrm{E}+00$ \\
\hline B1YR93 & 27.3 & $4.16 \mathrm{E}+01$ & $2.11 \mathrm{E}-03$ & $5.27 \mathrm{E}+05$ & $2.67 \mathrm{E}+01$ & $1.28 \mathrm{E}+00$ \\
\hline B1YRH3-2 & 29.0 & $7.36 \mathrm{E}+01$ & $5.02 \mathrm{E}-03$ & $6.75 \mathrm{E}+05$ & $4.60 \mathrm{E}+01$ & $1.25 \mathrm{E}+00$ \\
\hline B1YRH4-2 & 30.8 & $3.03 \mathrm{E}+01$ & $5.27 \mathrm{E}-03$ & $2.38 \mathrm{E}+05$ & $4.15 \mathrm{E}+01$ & $9.60 \mathrm{E}-01$ \\
\hline B1YR95 & 31.8 & $4.99 \mathrm{E}+01$ & 7.49E-03 & $5.07 \mathrm{E}+05$ & $7.61 \mathrm{E}+01$ & $1.32 \mathrm{E}+00$ \\
\hline B1YRH5-2 & 33.2 & $3.11 \mathrm{E}+01$ & $1.29 \mathrm{E}+00$ & $3.22 \mathrm{E}+05$ & $1.33 \mathrm{E}+04$ & $1.12 \mathrm{E}+00$ \\
\hline B1YR96 & 34.2 & $1.36 \mathrm{E}+01$ & $1.96 \mathrm{E}-01$ & $1.28 \mathrm{E}+05$ & $1.84 \mathrm{E}+03$ & $7.26 \mathrm{E}-01$ \\
\hline B1YRH6-2 & 36.7 & $2.35 \mathrm{E}+01$ & $4.89 \mathrm{E}-01$ & $1.59 \mathrm{E}+05$ & $3.30 \mathrm{E}+03$ & $6.65 \mathrm{E}-01$ \\
\hline B1YR97 & 37.7 & $1.80 \mathrm{E}+01$ & $3.93 \mathrm{E}-01$ & $1.53 \mathrm{E}+05$ & $3.35 \mathrm{E}+03$ & $9.42 \mathrm{E}-01$ \\
\hline B1YRH7-2 & 38.5 & $8.83 \mathrm{E}+00$ & $2.20 \mathrm{E}-01$ & $9.13 \mathrm{E}+04$ & $2.27 \mathrm{E}+03$ & $6.46 \mathrm{E}-01$ \\
\hline B1YR98 & 39.5 & $9.62 \mathrm{E}+00$ & $3.12 \mathrm{E}-01$ & $8.02 \mathrm{E}+04$ & $2.60 \mathrm{E}+03$ & $8.53 \mathrm{E}-01$ \\
\hline B1YRH8-2 & 41.0 & $2.17 \mathrm{E}+01$ & $8.21 \mathrm{E}-03$ & $4.41 \mathrm{E}+05$ & $1.67 \mathrm{E}+02$ & $1.58 \mathrm{E}+00$ \\
\hline B1YRB1 & 44.7 & $3.04 \mathrm{E}+01$ & $5.42 \mathrm{E}-02$ & $4.56 \mathrm{E}+05$ & $8.13 \mathrm{E}+02$ & $2.22 \mathrm{E}+00$ \\
\hline B1YRJ1-2 & 46.1 & $6.48 \mathrm{E}+01$ & $2.50 \mathrm{E}-02$ & $1.67 \mathrm{E}+06$ & $6.43 \mathrm{E}+02$ & $3.65 \mathrm{E}+00$ \\
\hline B1YRJ2-2 & 48.5 & $7.37 \mathrm{E}+01$ & $5.41 \mathrm{E}-02$ & $2.21 \mathrm{E}+06$ & $1.62 \mathrm{E}+03$ & $3.81 \mathrm{E}+00$ \\
\hline B1YRB3 & 49.5 & $4.29 \mathrm{E}+01$ & $6.01 \mathrm{E}-02$ & $1.18 \mathrm{E}+06$ & $1.66 \mathrm{E}+03$ & $3.34 \mathrm{E}+00$ \\
\hline B1YRJ3-2 & 51.4 & $5.05 \mathrm{E}+01$ & $2.70 \mathrm{E}-02$ & $1.87 \mathrm{E}+06$ & $1.00 \mathrm{E}+03$ & $4.23 \mathrm{E}+00$ \\
\hline B1YRJ4-2 & 53.5 & $3.86 \mathrm{E}+01$ & $9.80 \mathrm{E}-02$ & $1.40 \mathrm{E}+06$ & $3.56 \mathrm{E}+03$ & $4.34 \mathrm{E}+00$ \\
\hline B1YRB5 & 56.0 & $5.25 \mathrm{E}+01$ & $3.09 \mathrm{E}-03$ & $1.74 \mathrm{E}+06$ & $1.02 \mathrm{E}+02$ & $4.22 \mathrm{E}+00$ \\
\hline B1YRB7 & 60.0 & $6.38 \mathrm{E}+01$ & $1.48 \mathrm{E}-03$ & $1.93 \mathrm{E}+06$ & $4.45 \mathrm{E}+01$ & $4.24 \mathrm{E}+00$ \\
\hline B1YRB8 & 62.5 & $2.33 \mathrm{E}+01$ & $5.96 \mathrm{E}-04$ & $9.58 \mathrm{E}+05$ & $2.45 \mathrm{E}+01$ & $2.37 \mathrm{E}+00$ \\
\hline B1YRB9 & 65.5 & $2.33 \mathrm{E}+01$ & $5.90 \mathrm{E}-04$ & $9.21 \mathrm{E}+05$ & $2.33 \mathrm{E}+01$ & $2.50 \mathrm{E}+00$ \\
\hline B1YRC0 & 67.5 & $1.41 \mathrm{E}+01$ & $8.32 \mathrm{E}-04$ & $5.23 \mathrm{E}+05$ & $3.10 \mathrm{E}+01$ & $2.84 \mathrm{E}+00$ \\
\hline B1YRH2 & 70.0 & $3.28 \mathrm{E}+01$ & $1.12 \mathrm{E}-03$ & $1.02 \mathrm{E}+06$ & $3.46 \mathrm{E}+01$ & $2.58 \mathrm{E}+00$ \\
\hline
\end{tabular}

The only potential radiological COCs that were measurable in the water extracts were technetium-99 and uranium-238. The concentrations of technetium-99 and uranium-238 on both a gram of sediment basis and as pore-water concentrations are listed in Table 3.7. Pore-water concentrations of waterextractable technetium-99 and uranium-238, as well as concentration of those on sediment as a function of depth, are also shown in Figure 3.4. The technetium-99 data show elevated water-extracted technetium- 99 concentrations in two shallow lobes of 25 to $35 \mathrm{ft}$ bgs and 45 to $60 \mathrm{ft} \mathrm{bgs}$. The distribution of technetium-99 concentrations is very similar to that of nitrate on sediments. Three maxima of 
technetium-99 concentrations at $29 \mathrm{ft}, 49 \mathrm{ft}$, and $60 \mathrm{ft}$ bgs are at exactly the same depths as the highest pore-water concentrations of nitrate found in C7047. These two mobile contaminants are often found to travel and distribute in the vadose zone in a similar pattern. Elevated water-extractable concentrations of uranium-238 are found in shallow vadose zone from $33 \mathrm{ft}$ to $40 \mathrm{ft}$ bgs where high $\mathrm{pH}$ and moisture content were found. Elevated pHs, EC, and uranium-238 concentration data in water extracts result from the presence of fine-grained silty sand beds located at between 30 and $40 \mathrm{ft}$ bgs. Narrow distribution of elevated uranium-238 concentrations found at relatively shallow depths suggests that uranium-238 is less mobile than technetium-99 and nitrate.

Compared to the data obtained at borehole C5923, in general, the profiles of water-extractable compositions for both boreholes C5923 and C7047 close to the 216-B-16 and 216-B-17 cribs are not simple. Complicated profiles of water-extractable compositions in these two boreholes are attributed to the effects of lateral spreading of penetrating waste plumes from the two cribs leading to a complicated mixture from both the east and west directions. However, the profiles of major cation and anion concentrations for these two boreholes are pretty much similar. Except for two peaks for nitrate and sodium concentrations at $37 \mathrm{ft}$ and $46 \mathrm{ft}$ bgs in C5923, relatively higher concentrations of nitrate and sodium are found in most of the sediments from C7047 rather than those in C5923. Higher concentrations of wastes in sediments of $\mathrm{C} 7047$ are considered to result from the closer location of borehole $\mathrm{C} 7047$ to the cribs. Distribution of technetium-99 concentrations at different depths is also similar for the two boreholes except for the relatively higher concentrations of technetium found in the shallow depth of C7047. The peak ionic strengths measured at borehole C7047 are also somewhat higher at $1.4 \mathrm{M}$ to $4.3 \mathrm{M}$ in the thin concentrated lobes of the plume from $25 \mathrm{ft}$ to $35 \mathrm{ft}$ and $45 \mathrm{ft}$ to $60 \mathrm{ft}$ bgs, respectively, than a peak ionic strength of $0.7 \mathrm{M}$ to $3.1 \mathrm{M}$ at the same range of depth in borehole C5923. A significant difference was found in uranium-238 concentration in water extracts between boreholes C5923 and C7047. Although no detectable uranium-238 concentration higher than natural background uranium-238 concentration was found in water extracts of C2923 borehole sediments at shallow depth above $70 \mathrm{ft}$ bgs, water extracts of $\mathrm{C} 7047$ sediments show a highly concentrated uranium-238 contamination in a shallow depth, especially between $30 \mathrm{ft}$ and $40 \mathrm{ft}$ bgs. The peak concentration of uranium-238 in water extracts of C7047 sediments reaches up to $1.3 \mu \mathrm{g} / \mathrm{g}$ at $33.2 \mathrm{ft}$ bgs. Considering that more wastes were disposed of in the two nearest cribs, B-16 and B-17, and the closer location of C7047 to those cribs, the high volume of waste plumes with elevated uranium concentration is considered to reach C7047 borehole sediments. High concentrations of uranium-238 on C7047 sediments also indicate the possibility of uranium remaining in waste solutions disposed of in $\mathrm{BC}$ Cribs and Trenches even after uranium recovery processes. Although no sediment samples were collected below $70 \mathrm{ft}$ bgs in $\mathrm{C} 7047$, the higher concentration and greater volume of wastes found in pore water and sediments at C7047 can lead one to expect deeper penetration of waste plumes in C7047 as was found in the nearby C5923 borehole.

\subsubsection{8-M Nitric Acid Extracts and Gamma Energy Analysis Results}

The amount of radionuclides extracted from the $\mathrm{C} 7047$ vadose zone sediment by 8 -M nitric acid is shown in Table 3.8 and Figure 3.5. The 8-M nitric acid extraction is a protocol used by the EPA to estimate the maximum concentrations of regulated metals in contaminated sediment. Aliquots of sediment from borehole $\mathrm{C} 7047$ were subjected to acid extraction to look for elevated quantities of selected constituents and radionuclides. The concentrations of technetium-99 in acid extracts of C7047 are very similar to those of technetium-99 in water extracts. Similar distribution of technetium-99 concentrations in both water and acid extracts as well as the same maxima depths in C7047 indicate there 
is no water-resistant technetium reaction with sediments. Some vadose zone sediments have reported higher technetium concentrations in acid extracts than in water extracts, which is attributed to stronger binding of technetium with iron oxides on sediments. However, much higher concentrations of uranium238 were found in acid extracts of $\mathrm{C} 7047$ sediments compared to those of water extracts. The peak concentration of acid-extractable uranium-238 is $3.4 \mu \mathrm{g} / \mathrm{g}$ at $33 \mathrm{ft}$ bgs where the highest water-extractable uranium-238 concentration is also found. Acid-extractable uranium-238 concentration also decreases with the depth below $33 \mathrm{ft}$ bgs, but the concentrations of uranium-238 in acid extracts are approximately 2.5 to 8 times higher than those in water extracts of sediments collected between $33 \mathrm{ft}$ and $50 \mathrm{ft}$ bgs. Higher concentration of uranium-238 in acid extracts indicates that there are more water-resistant uranium-238 phases, such as (co)precipitates and strongly bound uranium-238, in either mineral surface or internal structure. Because of highly caustic waste solutions from the leaking storage tanks, the presence of uranium-silicate mineral precipitates (boltwoodite and/or uranophane) is found in Hanford 200 Area sediments (Um et al. 2009). In addition, uranium incorporation within mineral structure or sorption on fine-grained particles makes the mass transfer of uranium leach slowly in water extracts. More detailed understanding of the uranium retention mechanism is required to identify uranium solid phases and predict uranium desorption or leaching from the contaminated sediments.
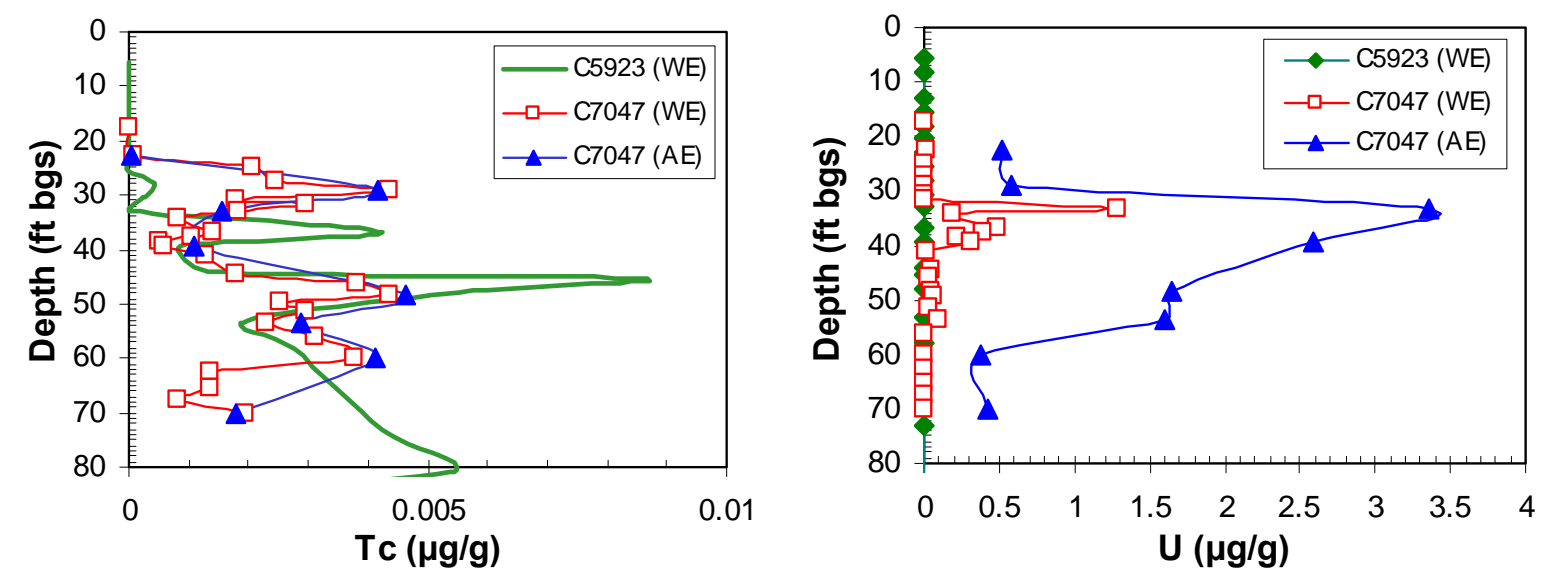

Figure 3.5. Acid-Extractable Technetium-99 (left) and Uranium-238 (right) in Sediments from Borehole C7047 with Comparison of Water-Extractable Technetium and Uranium-238 from C5923 and $\mathrm{C} 7047$

Table 3.8. Acid-Extractable Radionuclides in Borehole C7047 Sediments

\begin{tabular}{lccc}
\hline $\begin{array}{c}\text { Sample } \\
(\text { HEIS ID) }\end{array}$ & $\begin{array}{c}\text { Mid-Depth } \\
(\mathrm{ft} \text { bgs })\end{array}$ & $\begin{array}{c}{ }^{99} \mathrm{Tc} \\
(\mathrm{pCi} / \mathrm{g})\end{array}$ & $\begin{array}{c}{ }^{238} \mathrm{U} \\
(\mu \mathrm{g} / \mathrm{g})\end{array}$ \\
\hline B1YR91 & 22.5 & $3.31 \mathrm{E}-01$ & $5.24 \mathrm{E}-01$ \\
B1YRH3-2 & 29.0 & $7.07 \mathrm{E}+01$ & $5.79 \mathrm{E}-01$ \\
B1YRH5-2 & 33.2 & $2.64 \mathrm{E}+01$ & $3.36 \mathrm{E}+00$ \\
B1YR98 & 39.5 & $1.86 \mathrm{E}+01$ & $2.58 \mathrm{E}+00$ \\
B1YRJ2-2 & 48.5 & $7.88 \mathrm{E}+01$ & $1.65 \mathrm{E}+00$ \\
B1YRJ4-2 & 53.5 & $4.87 \mathrm{E}+01$ & $1.60 \mathrm{E}+00$ \\
B1YRB7 & 60.0 & $6.98 \mathrm{E}+01$ & $3.74 \mathrm{E}-01$ \\
B1YRH2 & 70.0 & $3.04 \mathrm{E}+01$ & $4.24 \mathrm{E}-01$ \\
\hline
\end{tabular}


Further, no elevated concentrations of other Resource Conservation and Recovery Act (RCRA)regulated metals and mercury were found. Because of the low detectable concentrations of those metals, the results are not reported in this document. Wet chemical separations on acid extracts of the samples were also performed to measure strontium-90 and nickel-63. However, the strontium-90 and nickel-63 activities were also all below detection limits in acid extracts.

Ten selected core samples in zones that contained high salt content in pore waters were directly counted by GEA. Manmade fission products measured by GEA are shown in Table 3.9. One sample measured at $46 \mathrm{ft}$ bgs in the field showed a very minor amount of cesium-137 $(0.2 \mathrm{pCi} / \mathrm{g})$. However, because the measured core samples in the laboratory did not show any detectable cesium- 137 in sediments collected at the depths close to $46 \mathrm{ft}$ bgs (Table 3.9) and the values measured in the field were very close to the detection limit of $\sim 0.15 \mathrm{pCi} / \mathrm{g}$, the detection of $0.2 \mathrm{pCi} / \mathrm{g}$ cesium- 137 found at $46 \mathrm{ft}$ bgs in the field can be considered to the counting uncertainty. Table 3.9 shows that no other manmade gamma-emitting radionuclides were seen in the sediments from C7047. The GEA of the selected grab samples from borehole $\mathrm{C} 7047$ did show background activities of natural potassium- 40 and daughter products of natural uranium-238 and thorium-232. These results are also very similar to those found in nearby borehole C5923.

Table 3.9. Manmade Fission Product GEA Data (pCi/g sediment) for Core Samples from C7047

\begin{tabular}{lccccccc}
\hline HEIS \# & $\begin{array}{c}\text { mid depth } \\
(\mathrm{ft} b g s)\end{array}$ & $\begin{array}{c}\text { Co-60 } \\
(\mathrm{pCi} / \mathrm{g})\end{array}$ & $\begin{array}{c}\text { Sb-125 } \\
(\mathrm{pCi} / \mathrm{g})\end{array}$ & $\begin{array}{c}\mathrm{Cs}-137 \\
(\mathrm{pCi} / \mathrm{g})\end{array}$ & $\begin{array}{c}\text { Eu-152 } \\
(\mathrm{pCi} / \mathrm{g})\end{array}$ & $\begin{array}{c}\text { Eu-154 } \\
(\mathrm{pCi} / \mathrm{g})\end{array}$ & $\begin{array}{c}\text { Eu-155 } \\
(\mathrm{pCi} / \mathrm{g})\end{array}$ \\
\hline B1YRH4-1 & 31.3 & $<0.31$ & $<0.79$ & $<0.34$ & $<1.02$ & $<0.57$ & $<0.83$ \\
B1YRH5-2 & 33.2 & $<0.14$ & $<0.39$ & $<0.16$ & $<0.48$ & $<0.27$ & $<0.38$ \\
B1YRH6-1 & 37.2 & $<0.14$ & $<0.42$ & $<0.15$ & $<0.55$ & $<0.29$ & $<0.44$ \\
B1YRH7-1 & 39.0 & $<0.12$ & $<0.40$ & $<0.14$ & $<0.54$ & $<0.27$ & $<0.44$ \\
B1YRH9-1 & 41.5 & $<0.12$ & $<0.36$ & $<0.14$ & $<0.44$ & $<0.24$ & $<0.34$ \\
B1YRJ0-2 & 43.7 & $<0.12$ & $<0.35$ & $<0.13$ & $<0.45$ & $<0.25$ & $<0.37$ \\
B1YRJ1-2 & 46.1 & $<0.12$ & $<0.38$ & $<0.15$ & $<0.44$ & $<0.25$ & $<0.35$ \\
B1YRJ1-1 & 46.6 & $<0.13$ & $<0.38$ & $<0.14$ & $<0.52$ & $<0.26$ & $<0.42$ \\
B1YRJ2-1 & 49.0 & $<0.12$ & $<0.35$ & $<0.14$ & $<0.42$ & $<0.24$ & $<0.34$ \\
B1YRJ4-1 & 54.0 & $<0.13$ & $<0.35$ & $<0.13$ & $<0.49$ & $<0.26$ & $<0.40$ \\
\hline
\end{tabular}

$<$ values $=$ below level of quantitation.

\subsubsection{Particle-Size Distribution of Sediments in Borehole C7047}

Particle-size data for eight selected core samples were collected after measuring saturated hydraulic conductivities for the same core samples. A dry sieving approach, rather than wet sieving, was adopted to minimize waste generation. However, dry sieving is known to cause an over-estimation of the coarse fraction, especially in sediments with high-fines content, because the fines can aggregate into sand and fine pebble-sized particles (Serne et al. 2009). However, previous particle-size analysis using a laser for the fine particles less than $63-\mu \mathrm{m}$ fraction for $\mathrm{C} 5923$ borehole sediments also produced very high-quality data that showed good continuity with dry-sieve measurements (Serne et al. 2009). Figures 3.6 shows the PSD data as determined by the weight percent passing each sieve plotted as a curve on a semi-logarithmic scale for the $\mathrm{C} 7047$ core samples. The resulting data represent the percentage of particles retained and passing through each sieve. The hydrometer method was used to quantify the silt and clay content for 
C7047 core sediments. Table 3.10 gives PSD information along with the modified Folk-Wentworth (Folk 1968, Wentworth 1922) classification for each composite sample.

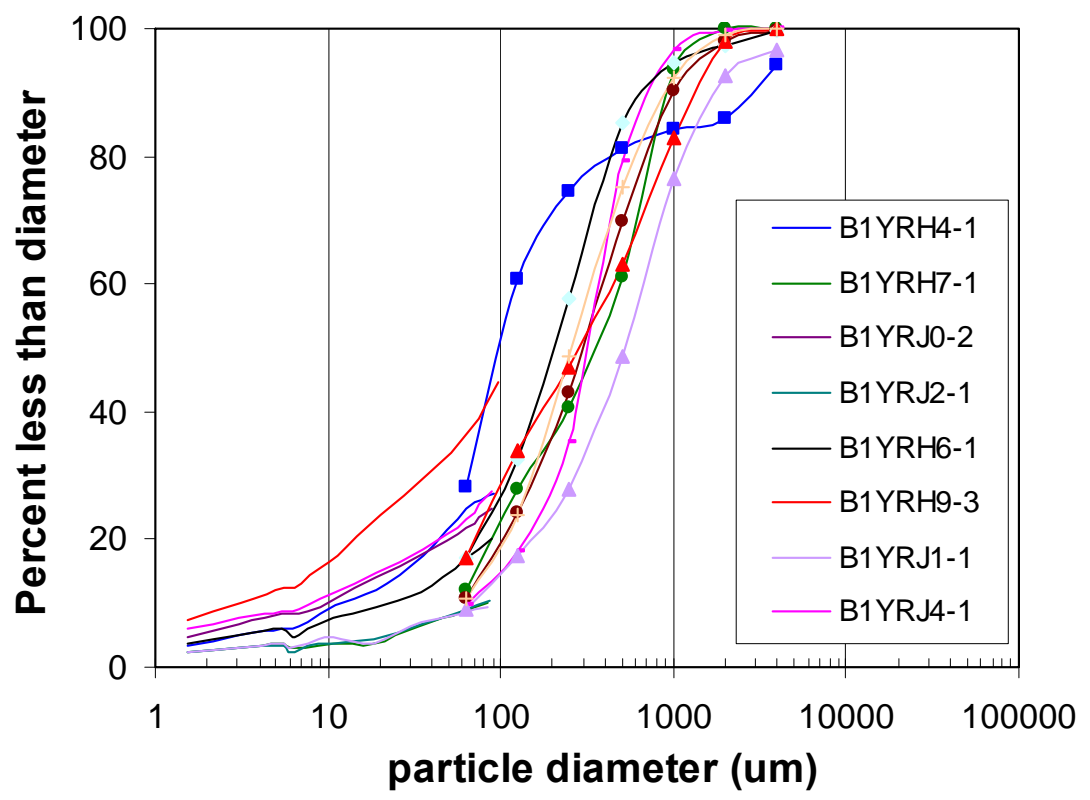

Figure 3.6. Particle-Size Distribution of the Selected Core Sediments from Borehole C7047. Lines with symbols indicate date from sieve and lines without symbols are from hydrometer analyses

The data show that most of the core samples consist of a sand-size fraction, ranging from $58 \%$ to $90 \%$, indicating a typical Hanford formation sand-dominated sequence. None of the samples contains significant fine-grained particles (silt plus clay), and the silt/clay fraction $(<63-\mu \mathrm{m})$ ranges from $9.9 \%$ to $32.5 \%$ with a mean of $14.9 \%$. The silt content ranges from $4.2 \%$ to $28.5 \%$, whereas the coarse fraction ranges from $0 \%$ to $8.2 \%$. The PSD, particularly of sand and silt fractions, has considerable practical value for the development of a fate and transport model to design appropriate remedies for contaminants in the subsurface environment, because both theory and experiments have shown that air and water permeability as well as surface area are strongly related to the effective particle diameter. Compared to PSD results from C5923, C7047 sediments show similar size fractions with less amounts of gravel (0$8.2 \%$ in $\mathrm{C} 7047$ vs. $0-50 \%$ in C5923) and clay fractions (2.2-8.7\% in C7047 vs. $1-12 \%$ in C5923). However, more silt and sand fractions are found in sediments of C7047.

Because the dry sieve and the hydrometer methods measure two different aspects of the sample (e.g., the sieve method measures the amount of material smaller than a specific diameter, while the hydrometer data measure the average diameter remaining in suspension), the two data curves in Figure 3.6 do not line up perfectly for some samples. However, the differences between the two curves are not great and are not expected to affect data analysis and future use. 
Table 3.10. Particle-Size Distributions as Determined by the Dry Sieve/Hydrometer Method for Core Samples from C7047

\begin{tabular}{cccccc}
\hline HEIS \# & Mid Depth (ft bgs) & Gravel (\%) & Sand (\%) & Silt (\%) & Clay (\%) \\
& & & & & \\
\hline B1YRH4-1 & 31.3 & 8.20 & 59.3 & 28.5 & 3.99 \\
B1YRH6-1 & 37.2 & 1.48 & 80.4 & 13.2 & 3.81 \\
B1YRH7-1 & 39.0 & 0.09 & 87.8 & 9.44 & 2.63 \\
B1YRH9-3 & 40.5 & 1.86 & 80.9 & 9.18 & 8.09 \\
B1YRJ0-2 & 43.7 & 2.08 & 87.3 & 5.30 & 5.34 \\
B1YRJ1-1 & 46.6 & 7.31 & 83.6 & 6.65 & 2.46 \\
B1YRJ2-1 & 49.0 & 0.34 & 89.8 & 7.66 & 2.20 \\
B1YRJ4-1 & 54.0 & 1.02 & 88.3 & 4.18 & 6.54 \\
\hline
\end{tabular}

\subsubsection{Specific Surface Area and CEC of Vadose Sediments from Borehole C7047}

The specific surface-area data for the 10 selected core samples from C7047 are shown in Table 3.11. Two additional core samples, B1YRH5-2 and B1YRJ1-2 at $33.1 \mathrm{ft}$ and $46.1 \mathrm{ft}$ bgs, respectively were added and analyzed for SSA and CEC using bulk size-fractioned samples after measuring saturated hydraulic conductivities. Because most of the sediment samples collected at the sediments below $20 \mathrm{ft}$ bgs in C7047 showed high salt contents, both before-washed and after-washed sediments using DI water for couple of hours were used for SSA measurements.

The measured SSA ranged from $1.66 \mathrm{~m}^{2} / \mathrm{g}$ to $19.1 \mathrm{~m}^{2} / \mathrm{g}$ and $2.17 \mathrm{~m}^{2} / \mathrm{g}$ to $25.1 \mathrm{~m}^{2} / \mathrm{g}$ for before-washed and after-washed sediments, respectively. A higher SSA result after the washing steps to remove porewater salts was found in most of the sediments collected at between $31 \mathrm{ft}$ and $46 \mathrm{ft}$ bgs where the finegrained silty beds are present. About a two times higher SSA value was found in after-washed sediment at $40.5 \mathrm{ft}$ bgs (B1YRH9-3) compared to that of before-washed sample in which the highest clay fraction (8.1 wt\%) was found among the sediments studied (Table 3.10 and 3.11). Even though high ionic strength was still found in the depth of $50 \mathrm{ft}$ to $60 \mathrm{ft}$ bgs, not much increased SSA values were found in even after-washed sediments, indicating that the effects of high salt precipitates on SSA are more related to the fine-grained particles. In general, SSA should increase with increasing clay and silt content and decrease with sand content. The sediments which show most of noticeably increased SSA data in afterwashed step compared to those of before-washed sediments also have relatively high content of the silt and clay fractions ( $12 \%$ to $28 \%$ at the depths of $30 \mathrm{ft}$ to $40 \mathrm{ft} \mathrm{bgs}$ ). The sediments collected at below $41 \mathrm{ft}$ bgs show about less than or equal to $11 \%$ of the silt and clay fractions, but no significant increase of SSA values after the sediment-washing step. Compared to the SSA of C5923, the SSA values collected from C7047 are similar, but show a little bit higher SSA values, especially on sediments collected at the shallow depth above $40 \mathrm{ft}$ bgs. 
Table 3.11. SSA and CEC for Borehole C7047 Vadose Zone Sediments

\begin{tabular}{lcccc}
\hline HEIS \# & $\begin{array}{c}\text { Mid Depth } \\
(\mathrm{ft} b g s)\end{array}$ & $\begin{array}{c}\text { SSA before } \\
\text { wash }\left(\mathrm{m}^{2} / \mathrm{g}\right)\end{array}$ & $\begin{array}{c}\text { SSA after } \\
\text { wash }\left(\mathrm{m}^{2} / \mathrm{g}\right)\end{array}$ & $\begin{array}{c}\text { CEC (\%) after wash } \\
(\mathrm{meq} / 100 \mathrm{~g})\end{array}$ \\
\hline B1YRH4-1 & 31.3 & $15.4 \pm 0.069$ & $18.7 \pm 0.111$ & $27.3 \pm 2.21$ \\
B1YRH5-2 & 33.1 & $11.5 \pm 0.050$ & $17.7 \pm 0.107$ & $18.3 \pm 1.15$ \\
B1YRH6-1 & 37.2 & $19.1 \pm 0.089$ & $25.1 \pm 0.138$ & $17.0 \pm 7.53$ \\
B1YRH7-1 & 39.0 & $6.19 \pm 0.042$ & $6.24 \pm 0.037$ & $14.6 \pm 6.06$ \\
B1YRH9-3 & 40.5 & $8.37 \pm 0.045$ & $16.0 \pm 0.098$ & $14.8 \pm 6.41$ \\
B1YRJ0-2 & 43.7 & $4.89 \pm 0.022$ & $6.88 \pm 0.040$ & $9.72 \pm 1.12$ \\
B1YRJ1-2 & 46.1 & $1.71 \pm 0.017$ & $4.06 \pm 0.028$ & $8.11 \pm 1.07$ \\
B1YRJ1-1 & 46.6 & $5.27 \pm 0.030$ & $4.67 \pm 0.026$ & $8.54 \pm 0.42$ \\
B1YRJ2-1 & 49.0 & $2.96 \pm 0.030$ & $2.66 \pm 0.029$ & $13.0 \pm 6.83$ \\
B1YRJ4-1 & 54.0 & $1.66 \pm 0.011$ & $2.17 \pm 0.043$ & $9.31 \pm 0.69$ \\
\hline
\end{tabular}

Because the high sodium-nitrate pore-water precipitates impact both measurements of SSA and CEC, the CEC values were measured using the after-washed sediments from borehole C7047. The measured CEC values are shown in Table 3.11. The after-washed sediments usually show low CEC values compared to those from sediments without rinsing in the C5923 borehole (Serne et al. 2009). The CEC values ranged from $8.11 \mathrm{meq} / 100 \mathrm{~g}$ to $27.3 \mathrm{meq} / 100 \mathrm{~g}$ for sediments of C7047. Higher CEC values than $10 \mathrm{meq} / 100 \mathrm{~g}$ were found at the depths between $31 \mathrm{ft}$ and $41 \mathrm{ft} \mathrm{bgs}$ and at $49.0 \mathrm{ft}$ bgs where most of high ionic strengths were found. A high content of fine silt and clays are also found in this region. Compared to CEC values in C5923 sediments, the CEC values of C7047 sediments are much higher than those found in C5923 which ranged from $3.23 \mathrm{meq} / 100 \mathrm{~g}$ to $9.28 \mathrm{meq} / 100 \mathrm{~g}$ with a mean value of 7.16 $\mathrm{meq} / 100 \mathrm{~g}$.

\subsubsection{Saturated Hydraulic Conductivity and Air Permeability of Sediments from Borehole C7047}

Table 3.12 shows the saturated hydraulic conductivity and air permeability data obtained from 8 selected cores from borehole $\mathrm{C} 7047$. The measured saturated hydraulic conductivity ranged from the lowest of $2.55 \mathrm{E}-07 \mathrm{~cm} / \mathrm{sec}$ at $40.5 \mathrm{ft}$ bgs to the highest of $1.58 \mathrm{E}-03 \mathrm{~cm} / \mathrm{sec}$ at $49.0 \mathrm{ft}$ bgs with a mean of $3.73 \mathrm{E}-04 \mathrm{~cm} / \mathrm{sec}$. Only one sediment showed extremely fast hydraulic conductivity, $1.58 \mathrm{E}-03 \mathrm{~cm} / \mathrm{sec}$ $(6.59 \mathrm{~cm} /$ hour $)$ at $49.0 \mathrm{ft}$ bgs. Most of the slow hydraulic conductivities found between $30 \mathrm{ft}$ and $40 \mathrm{ft}$ bgs are related with the presence of fine-grained silt beds. Sediment collected at $40.5 \mathrm{ft}$ bgs showed the lowest hydraulic conductivity, because of the high content of clay fraction. Discharge versus hydraulic head for all of the samples showed the expected linear response for heads between $5 \mathrm{~cm}$ and $30 \mathrm{~cm}$, which indicates the good quality of the data. Compared to the measured hydraulic conductivities of C5923, borehole C7047 shows relatively lower hydraulic conductivities than those of C5923. 
Table 3.12. Saturated Hydraulic Conductivity and Air-Permeability Measurements for Borehole C7047 Vadose Zone Sediments

\begin{tabular}{lccccc}
\hline HEIS \# & $\begin{array}{c}\text { Mid Depth } \\
(\mathrm{ft} b g s)\end{array}$ & $\begin{array}{c}\text { Saturated Hydraulic } \\
\text { Conductivity } \\
(\mathrm{cm} / \mathrm{s})\end{array}$ & $\begin{array}{c}\text { Saturated Hydraulic } \\
\text { Conductivity } \\
(\mathrm{ft} / \mathrm{day})\end{array}$ & $\begin{array}{c}\text { Intrinsic Air } \\
\text { Permeability } k \\
\left(\mathrm{~m}^{2}\right)\end{array}$ & $\begin{array}{c}\text { Air } \\
\text { Permeability } \\
(\mathrm{cm} / \mathrm{hour})\end{array}$ \\
\hline B1YRH4-1 & 31.3 & $1.11 \mathrm{E}-05 \pm 5.57 \mathrm{E}-07$ & $3.13 \mathrm{E}-02 \pm 1.58 \mathrm{E}-03$ & $2.03 \mathrm{E}-12$ & $3.94 \mathrm{E}-02$ \\
B1YRH6-1 & 37.2 & $1.96 \mathrm{E}-05 \pm 5.19 \mathrm{E}-07$ & $5.56 \mathrm{E}-02 \pm 1.47 \mathrm{E}-03$ & $2.73 \mathrm{E}-10$ & $5.27 \mathrm{E}+00$ \\
B1YRH7-1 & 39.0 & $3.62 \mathrm{E}-04 \pm 1.13 \mathrm{E}-05$ & $1.03 \mathrm{E}+00 \pm 3.20 \mathrm{E}-02$ & $1.16 \mathrm{E}-11$ & $2.24 \mathrm{E}-01$ \\
B1YRH9-3 & 40.5 & $2.55 \mathrm{E}-07 \pm 6.43 \mathrm{E}-09$ & $7.23 \mathrm{E}-04 \pm 1.82 \mathrm{E}-05$ & $2.85 \mathrm{E}-11$ & $5.51 \mathrm{E}-01$ \\
B1YRJ0-2 & 43.7 & $1.53 \mathrm{E}-04 \pm 3.62 \mathrm{E}-06$ & $4.33 \mathrm{E}-01 \pm 1.03 \mathrm{E}-02$ & $1.41 \mathrm{E}-11$ & $2.74 \mathrm{E}-01$ \\
B1YRJ1-1 & 46.6 & $8.43 \mathrm{E}-04 \pm 4.69 \mathrm{E}-05$ & $2.39 \mathrm{E}+00 \pm 1.33 \mathrm{E}-01$ & $1.20 \mathrm{E}-11$ & $2.32 \mathrm{E}-01$ \\
B1YRJ2-1 & 49.0 & $1.58 \mathrm{E}-03 \pm 1.00 \mathrm{E}-04$ & $4.48 \mathrm{E}+00 \pm 2.84 \mathrm{E}-01$ & $2.78 \mathrm{E}-11$ & $5.38 \mathrm{E}-01$ \\
B1YRJ4-1 & 54.0 & $1.42 \mathrm{E}-05 \pm 4.41 \mathrm{E}-07$ & $4.03 \mathrm{E}-02 \pm 1.25 \mathrm{E}-03$ & $1.36 \mathrm{E}-11$ & $2.64 \mathrm{E}-01$ \\
\hline
\end{tabular}

Table 3.12 also presents a summary of the air permeability for core samples from borehole C7047. Air permeability was measured at the antecedent moisture to gain insight into air permeability under field conditions to provide realistic information for the design and operation of the soil desiccation systems that is planned to be used at the BC Cribs and Trenches Area. The values presented in Table 3.12 represent the intrinsic air permeability, $k_{a}$, and equivalent air permeability value to the saturated hydraulic conductivity $(\mathrm{cm} / \mathrm{hr})$. The intrinsic air permeability ranged from $2 \times 10^{-12} \mathrm{~m}^{2}$ to $2.73 \times 10^{-10} \mathrm{~m}^{2}$ with a mean value of $4.8 \times 10^{-11} \mathrm{~m}^{2}$. The pneumatic conductivity ranged from $0.039 \mathrm{~cm} / \mathrm{hr}$ to $5.27 \mathrm{~cm} / \mathrm{hr}$ with a mean value of $0.93 \mathrm{~cm} / \mathrm{hr}$. Because the hydraulic conductivity of soil depends on properties of both the soil matrix and moving fluid, the soil permeability is a function of the soil's pore-space characteristics, that is, porosity, pore-size distribution, pore shape, pore tortuosity, and connectivity (Serne et al. 2009). The intrinsic air permeability is therefore a measure of the average cross-sectional area of the pores conducting air in units of square meters and has shown somewhat of a correlation with saturated hydraulic conductivity.

Samples showing high moisture content are considered to be typically finer in texture and show low conductivities for both air and water than coarser and drier samples that show high conductivities for both air and water. Sediment with the lowest hydraulic conductivity at $40.5 \mathrm{ft}$ bgs did not show the lowest air permeability among sediments collected in C7047. Lowest air permeability was found in the sediment collected at $31.3 \mathrm{ft} \mathrm{bgs}$ in which a higher content of silt and clay fractions (32.5\%) was found. However, this sediment also had the highest gravel content, $8.2 \%$, so that the measured hydraulic conductivity was not the lowest among the collected sediments in C7047. Compared to measured air permeability values in C5923, borehole C7047 showed similar but a little bit higher air permeability values than those of C5923 sediments, especially those collected at shallow depths above $70 \mathrm{ft}$ bgs. This contrary trend between hydraulic conductivity and air permeability between the two boreholes is considered to result from many unknown parameters affecting those measured values as described above. Nonetheless, these data collected from the boreholes C5923 and C7047 provide an important database for field measurements of air permeability to be used for desiccation treatability testing. 


\subsection{Conclusions}

This section provides a summary of the geochemical and hydrologic findings on the sediments obtained from borehole 299-E13-65 (C7047) at the BC Cribs and Trenches Area. The physical and geochemical properties were characterized for the selected grab and core sediment samples from borehole 299-E13-65 (C7047) to augment data previously collected from adjacent borehole 299-E13-62 (C5923), which is located about $39.1 \mathrm{ft}$ southwest of C7047 between the 216-B-16 and 216-B-17 cribs.

As a function of collection depths, the measured moisture content of $\mathrm{C} 7047$ has a profile similar to that of C5923, but shows relatively higher moisture contents especially between $30 \mathrm{ft}$ and $40 \mathrm{ft}$ bgs. Higher moisture contents are closely related to the presence of fine-grained silty beds in this depth range. Because of their close proximity to C5923, the sediments collected from C7047 and C5923 show very similar profiles of 1:1 water-extracted ions and radionuclides. However, higher $\mathrm{pH}, \mathrm{EC}$, ionic strength values found in the sediments of C7047 are attributed to the closer location of C7047 borehole to the two nearby cribs, 216-B-16 and 216-B-17 that were the major source of the liquid wastes that created the vadose zone plume. The closer location of $\mathrm{C} 7047$ to the cribs causes more waste to contact the sediments in C7047. Concentrations of mobile nitrate and technetium-99 either in pore-water solution or on sediments of C7047 are similar to the profiles of those in C5923, except that higher concentrations are found at shallow depths above $35 \mathrm{ft}$ bgs in C7047. A highly contaminated uranium-238 plume was found in $\mathrm{C} 7047$ at the depths of $30 \mathrm{ft}$ to $40 \mathrm{ft}$ bgs, consistent with elevated $\mathrm{pH}$ in pore water $(>9.0 \mathrm{pH})$ and indicative of caustic waste plume contact with the sediments. The GEA of selected core samples did not detect any discernable manmade gamma-emitting radionuclides. The total chemical composition of selected sediment samples was measured by strong nitric acid extraction and the results also show no measurable RCRA metals, mercury, and strontium-90 and nickel-63. The gross alpha and beta results for the acid extracts did not show any signs of unaccounted for radioactivity beyond that found in the specific analyses.

Hydrologic characterization results also show that most of sediments collected in C7047 consist of sand-size fractions with varying amount of silt/clay and gravel contents. The PSD, especially silt/clay contents, are considered to relate closely with surface area results, saturated hydraulic conductivity, and air permeability values. Sediment collected at $40.5 \mathrm{ft}$ bgs has high clay contents and exhibits the lowest saturated hydraulic conductivity. Because of the effect of high salt concentration from penetrating waste plumes, the pre-washing procedure is highly recommended to remove any remaining salt precipitates on the sediments before measuring the SSA and CEC. Although the two borehole sediments studied show similar hydrologic properties, relatively higher values of SSA, CEC, and air permeability were found in C7047, while slightly lower values of saturated hydraulic conductivity were found in C5923.

Based on the geochemical and hydrologic characterization results, more waste liquids migrated laterally through the shallow sediments at C7047 than at the more distant C5923 borehole. This study provided additional geochemical and hydrologic data to increase our understanding of site sediment characterizations and contaminant profiles prior to operating the SDPT in the BC Cribs and Trenches Area. The sediments contaminated by highly elevated uranium- 238 concentrations found between $30 \mathrm{ft}$ and $40 \mathrm{ft}$ bgs need to be investigated more thoroughly using sophisticated techniques to unveil the uranium-238 solid phases and understand mobility of uranium-238. 


\subsection{References}

American Society of Agronomy (ASA). 1996. Methods of Soil Analysis-Part 3, Chemical Methods, SSSA Book Series 5, ed DL Sparks. Soil Science Society of America/American Society of Agronomy, Madison, Wisconsin.

American Society for Testing and Materials (ASTM). 1993. Standard Practice for Description and Identification of Soils (Visual-Manual Procedure). D2488-93, American Society for Testing and Materials, West Conshohocken, Pennsylvania.

American Society for Testing and Materials (ASTM). 1998. Test Method for Laboratory

Determinationof Water (Moisture) Content of Soil and Rock by Mass. D22 16-98, American Society for Testing and Materials, West Conshohocken, Pennsylvania.

American Society of Testing and Materials (ASTM). 2006. Standard Test Method for Particle-Size Analysis of Soils. ASTM D422-63, American Society for Testing and Materials, West Conshohocken, Pennsylvania.

Benecke MW. 2008. Data Quality Objectives Summary Report for the BC Cribs and Trenches AreaHigh-Resolution Resistivity Correlation (DQO). SGW-32480, Rev. 0. Fluor Hanford, Inc., Richland, Washington.

Brunauer S, PH Emmett, and E Teller. 1938. "Adsorption of Gases in Multimolecular Layers." Journal of the American Chemical Society 60:309-319.

Corbin RA, BC Simpson, MJ Anderson, WF Danielson III, JG Field, TE Jones, and CT Kincaid. 2005. Hanford Soil Inventory Model, Rev 1. RPP-26744, CH2M-HILL Hanford Group, Inc., Richland, Washington. (This document was also released at the same time as PNNL-15367 by Pacific Northwest National Laboratory, Richland, Washington.)

Folk, RL. 1968. Petrology of Sedimentary Rocks. Hemphill, Austin, Texas.

Goggin DJ, RL Thrasher, and LW Lake. 1988. "A Theoretical and Experimental Analysis of Mini permeameter Response Including Gas Slippage and High Velocity Flow Effects, In Situ." Journal of Hydrology 12(1-2):79-116.

Gregg SJ and KSW Sing. 1982. Adsorption, surface area, and porosity. $2^{\text {nd }}$ edition. Academic Press, Inc., Orlando, Florida.

Pacific Northwest Laboratory (PNL). 1990. Procedures for Groundwater Investigations. PNL MA-567, Pacific Northwest Laboratory, Richland, Washington. ${ }^{\mathrm{a}}$

Pacific Northwest National Laboratory (PNNL). 1997. Gamma Energy Analysis Operation and Instrument Verification Using the Genie2000 TM Support Software. PNNL-RRL-01, Pacific Northwest National Laboratory, Richland, Washington.

\footnotetext{
${ }^{\mathrm{a}}$ This reference is an internal manual and not publicly available.
} 
Pacific Northwest National Laboratory (PNNL). 1998. Inductively Coupled Plasma Mass

Spectrometric(ICP-MS) Analysis. PNNL-AGG-415, Pacific Northwest National Laboratory, Richland, Washington.

Pacific Northwest National Laboratory (PNNL). 2005. Soil Water Content. PNNL-AGG-WC-001 Rev. 0, Pacific Northwest National Laboratory, Richland, Washington.

Rhoades JD. 1996. "Salinity: Electrical Conductivity and Total Dissolved Solids." In: Methods of Soil Analysis Part 3, ed JM Bigham. American Society of Agronomy, Madison, Wisconsin.

Serne RJ, AL Ward, W Um, BN Bjornstad, DF Rucker, DC Lanigan, and MW Benecke. 2009. Electrical Resistivity Correlation to Vadose Zone Sediment and Pore-Water Composition for the BC Cribs and Trenches Area. PNNL-17821, Pacific Northwest National Laboratory, Richland, Washington.

Suarez DL. 1996. "Chapter 20-Beryllium, Magnesium, Calcium, Strontium, and Barium.” In American Society of Agronomy (ASA). Methods of Soil Analysis-Part 3, Chemical Methods, SSSA Book Series 5, ed DL Sparks. Soil Science Society of America, Madison, Wisconsin.

Tidwell VC and JL Wilson. 1997. "Laboratory Method for Investigating Permeability Upscaling." Water Resources Research 33(7):1607-1616.

Lamb H. 1994. Hydrodynamics. $6^{\text {th }}$ edition. Cambridge University Press.

Um W, RJ Serne, Z Wang, CF Brown, BD Williams, CJ Dodge, and AJ Francis. 2009.

"Uranium Phases in Contaminated Sediments below Hanford's U Tank Farm." Environmental Science and Technology 43:4280-4286.

U.S. Department of Energy (DOE). 2007. Deep Vadose Zone Treatability Test Plan for the Hanford Central Plateau. DOE/RL-2007-56, Rev.0, U.S. Department of Energy, Richland Operations Office, Richland, Washington.

U.S. Environmental Protection Agency (EPA). 1984. "Determination of Inorganic Anions.” EPA Method 300.0A, in Test Method for the Determination of Inorganic Anions in Water by Ion Chromatography. EPA-600/4-84-0 17, U.S. Environmental Protection Agency, Washington, D.C.

U.S. Environmental Protection Agency (EPA). 2000a. "Acid Digestion of Sediments, Sludges, and Soils." EPA Method 3050B, in Test Methods for Evaluating Solid Waste, Physical/Chemical Methods. SW-846, U.S. Environmental Protection Agency, Washington, D.C. Accessed Sept. 20, 2008 at http://www.epa.gov/epaoswer/hazwaste/test/sw846.htm..

U.S. Environmental Protection Agency (EPA). 2000b. "Inductively Coupled Plasma-Atomic Emission Spectrometry." EPA Method 6010B, in Test Methods for Evaluating Solid Waste, Physical/Chemical Methods. SW-846, U.S. Environmental Protection Agency, Washington, D.C. Accessed Sept. 20, 2008 at http://www.epa.gov/epaoswer/hazwaste/test/sw846.htm.

U.S. Environmental Protection Agency (EPA). 2000c. "Inductively Coupled Plasma-Mass Spectrometry." EPA Method 6020, in Test Methods for Evaluating Solid Waste, Physical/Chemical Methods. SW-846, U.S. Environmental Protection Agency, Washington, D.C. Accessed Sept. 20, 2008 at http://www.epa.gov/epaoswer/hazwaste/test/sw846.htm. 
U.S. Geological Survey (USGS). 2004. "Alkalinity and Acid Neutralizing Capacity.” In National Field Manual for the Collection of Water-Quality Data, Second Edition. ed SA Rounds and FD Wilde. Accessed Sept. 20, 2008 at http://water.usgs.gov/owq/FieldManual/Chapter6/section6.6/html/section6.6.htm.

Webb PA and C Orr. 1997. Analytical Methods in Fine Particle Technology. Micromeritics Instrument Corp., Norcross, GA 30093.

Wentworth CK. 1922. "A Grade Scale and Class Terms for Clastic Sediments." Journal of Geology 30:377-392. 


\section{Appendix A}

\section{Well Summary, Borehole Logs, and Geologic Logs for Borehole 299-E13-65 (C7047) in the BC Cribs and Trenches Area}



Appendix A: Well Summary, Borehole Logs, and Geologic Logs for Borehole 299-E13-65 (C7047) in the BC Cribs and Trenches Area 


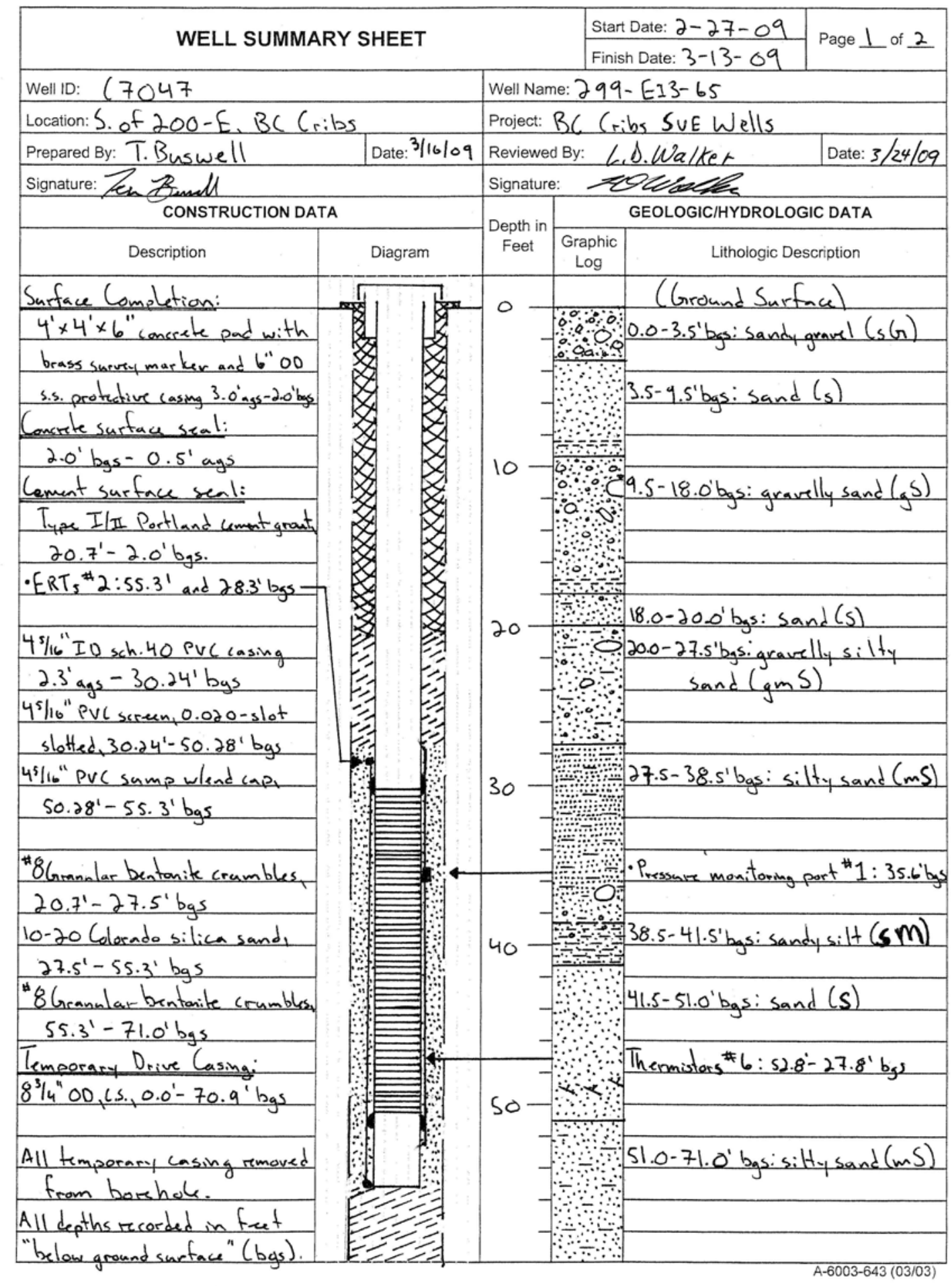

Figure A.1. C7047 Well Summary, Page 1 


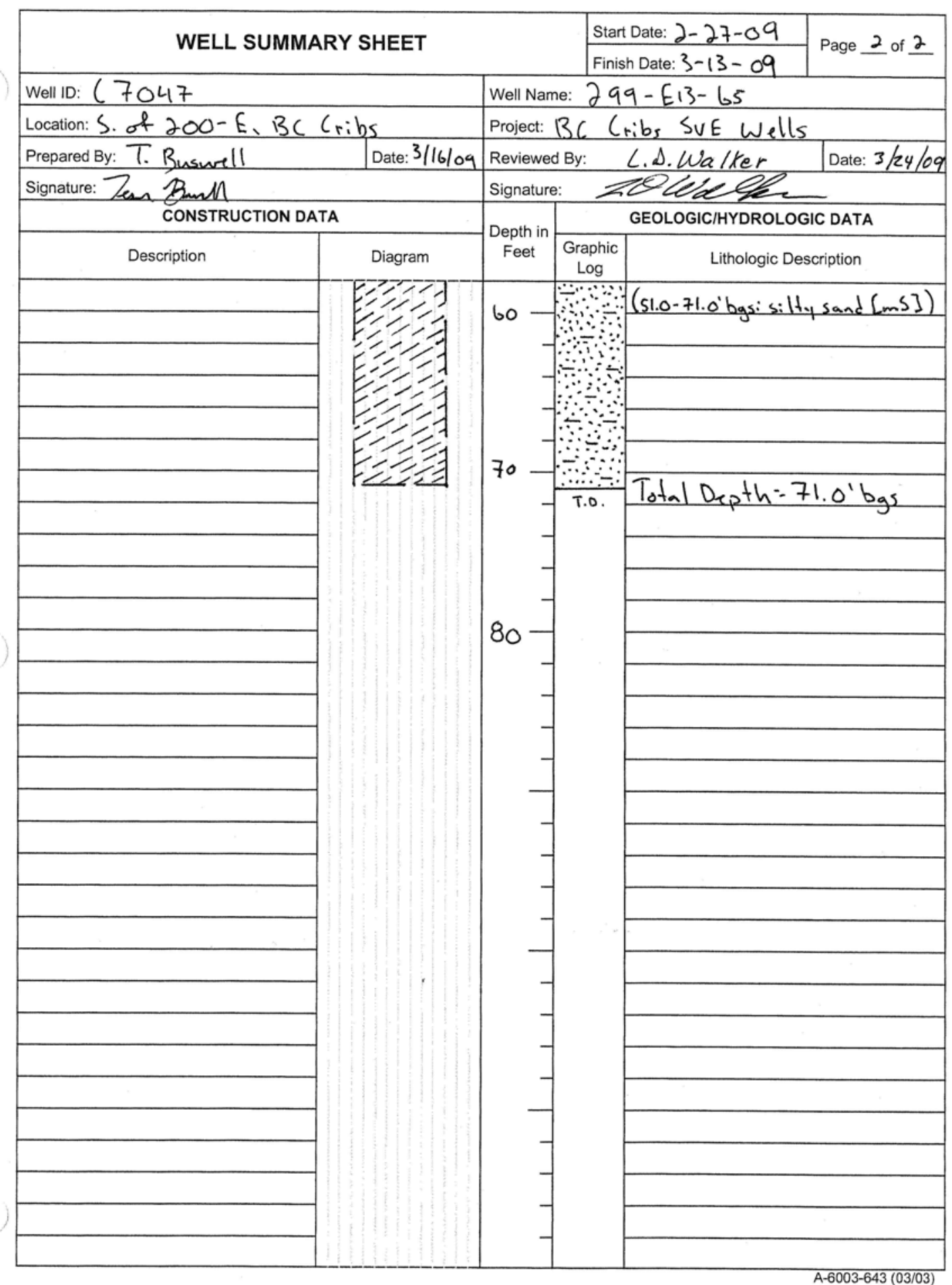

Figure A.2. C7047 Well Summary, Page 2 


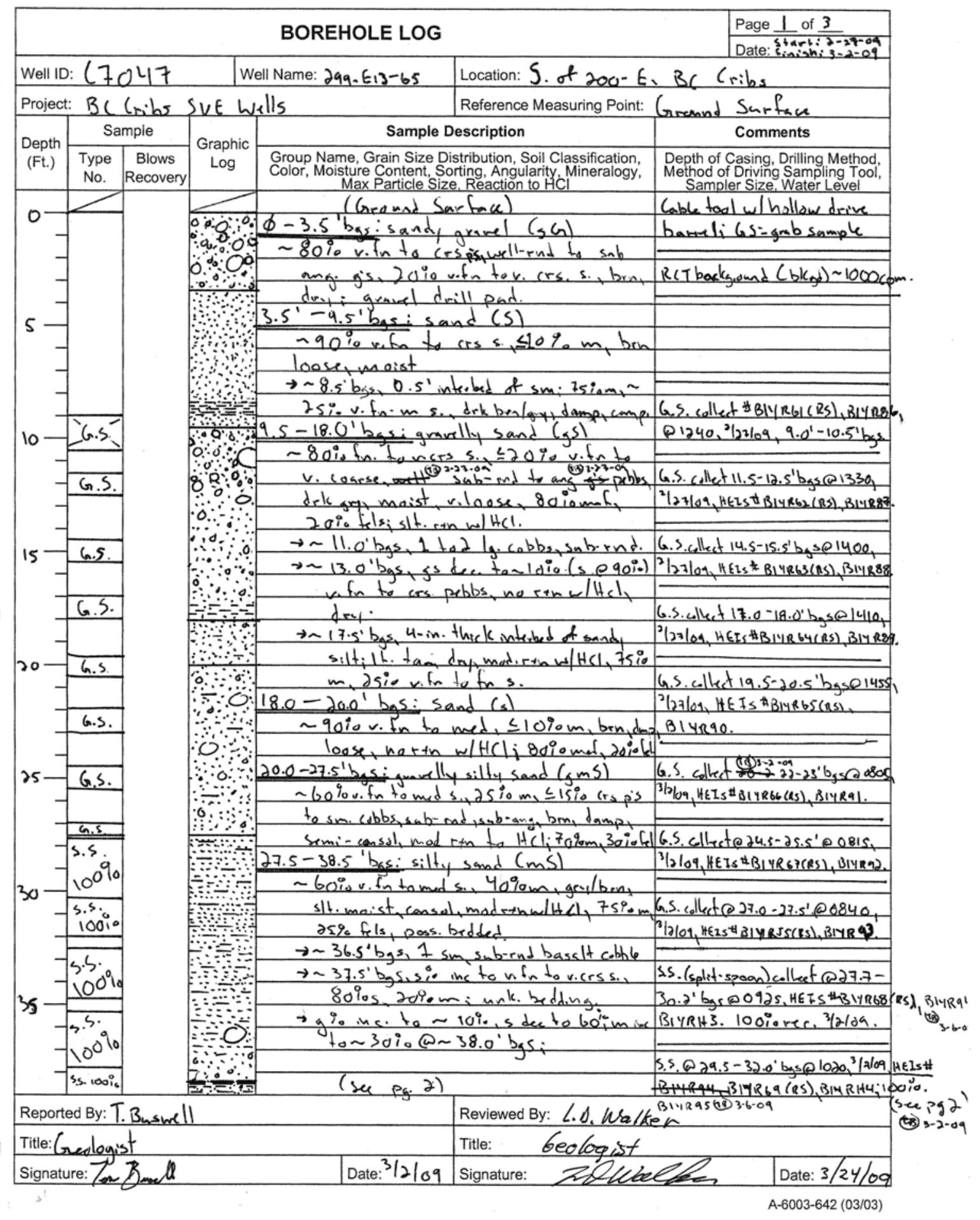

Figure A.3. C7047 Borehole Log, Page 1 


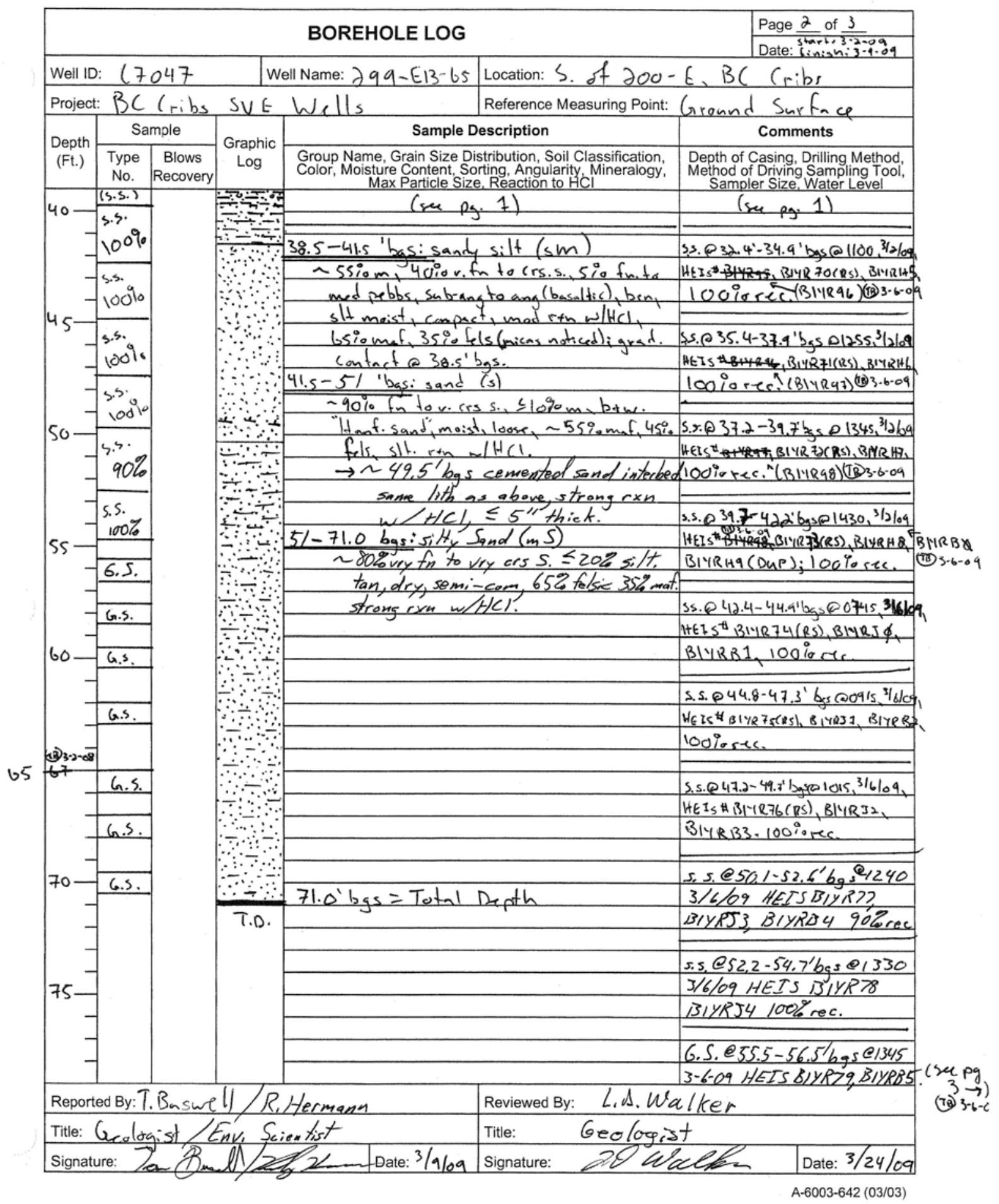

Figure A.4. C7047 Borehole Log, Page 2 


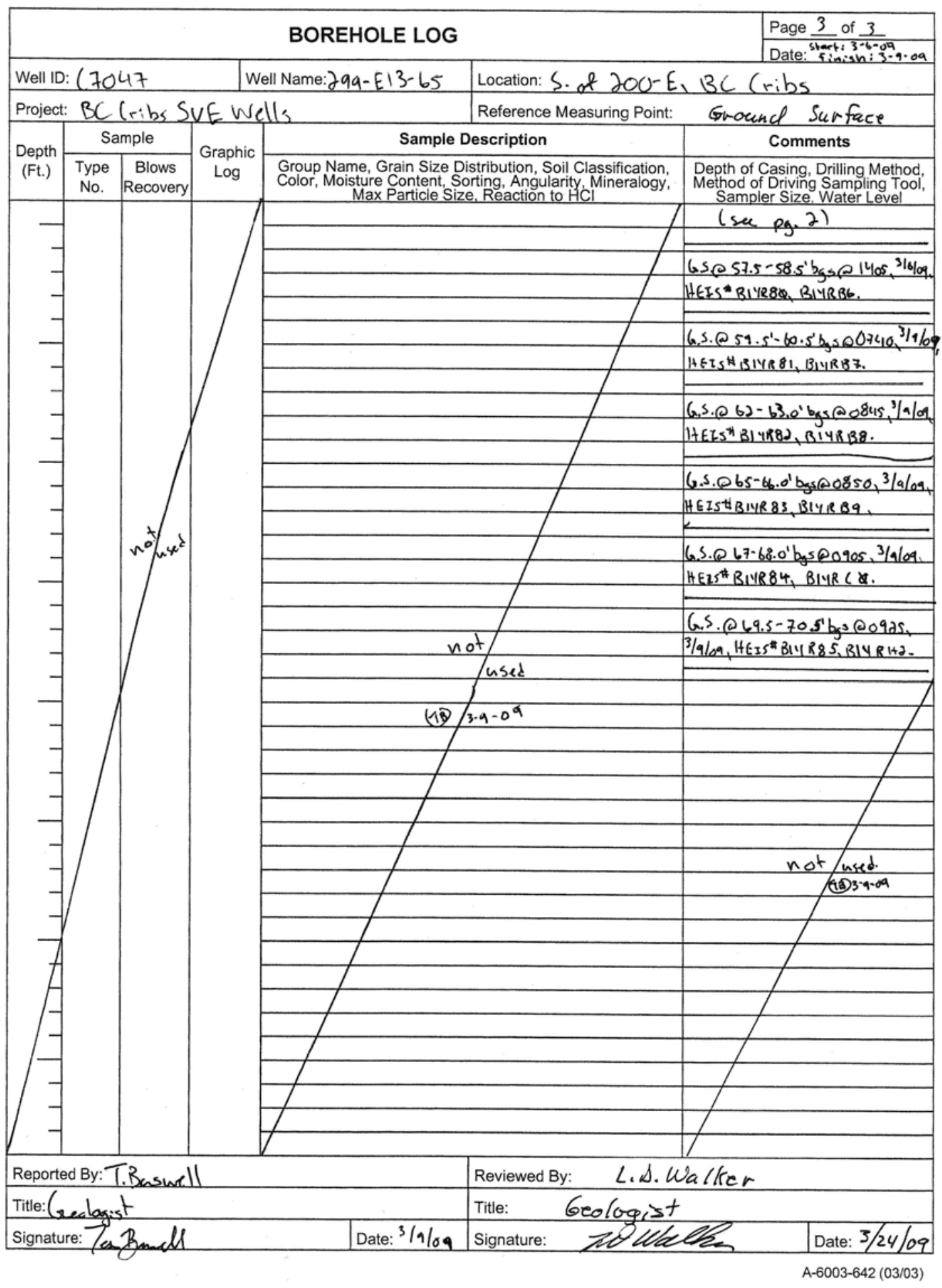

Figure A.5. C7047 Borehole Log, Page 3 


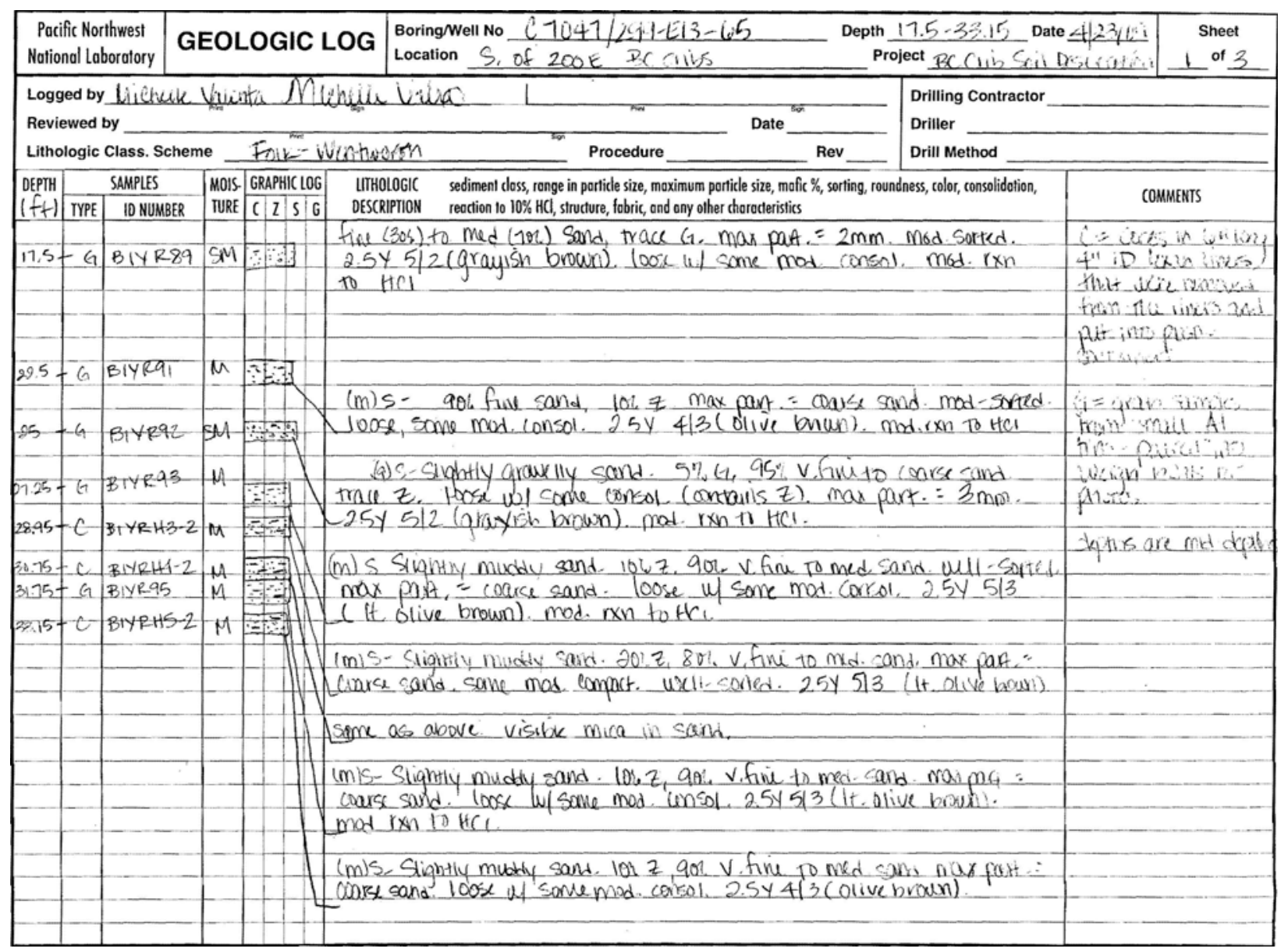

Figure A.6. C7047 Geologic Log, Page 1 


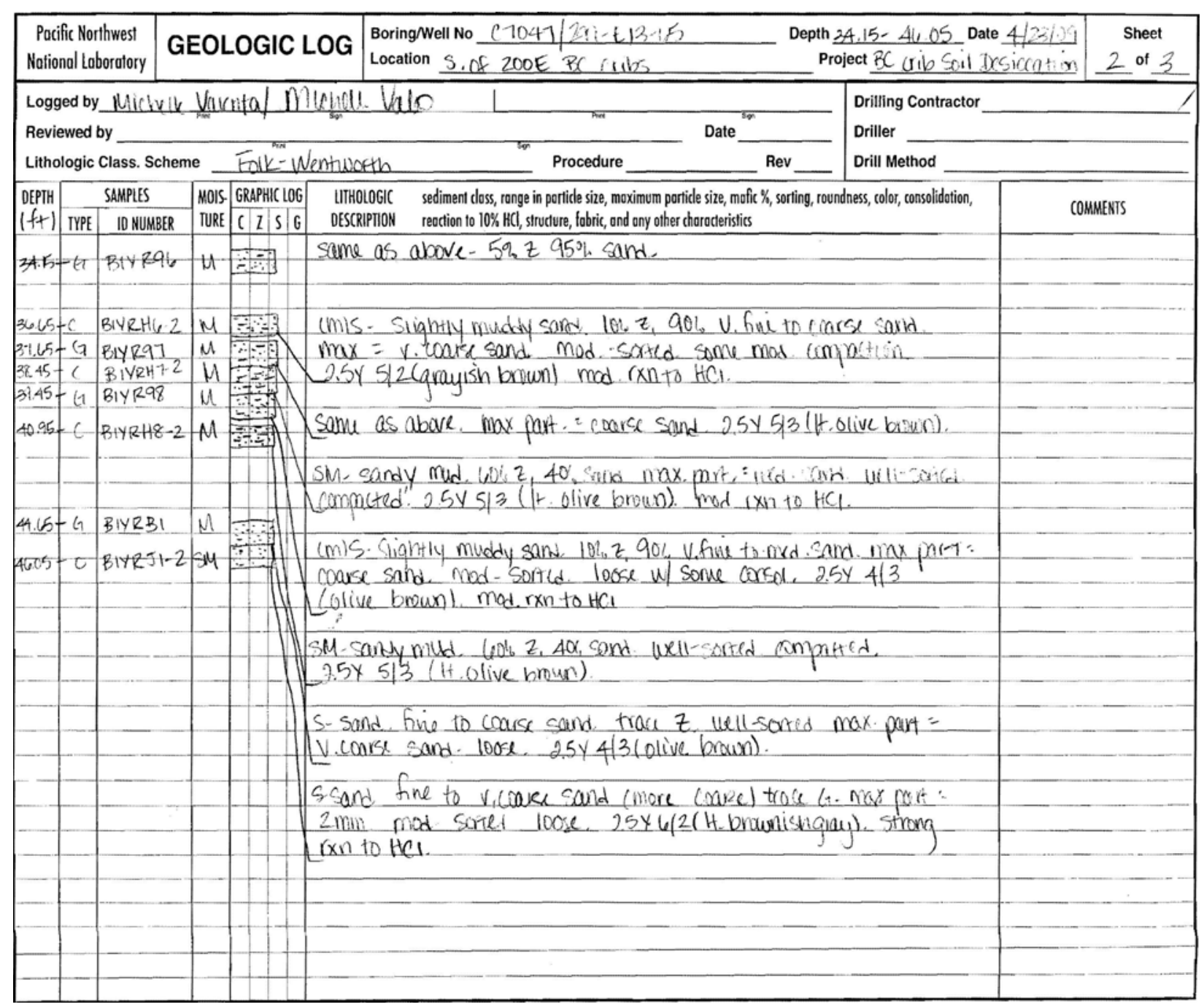

Figure A.7. C7047 Geologic Log, Page 2 


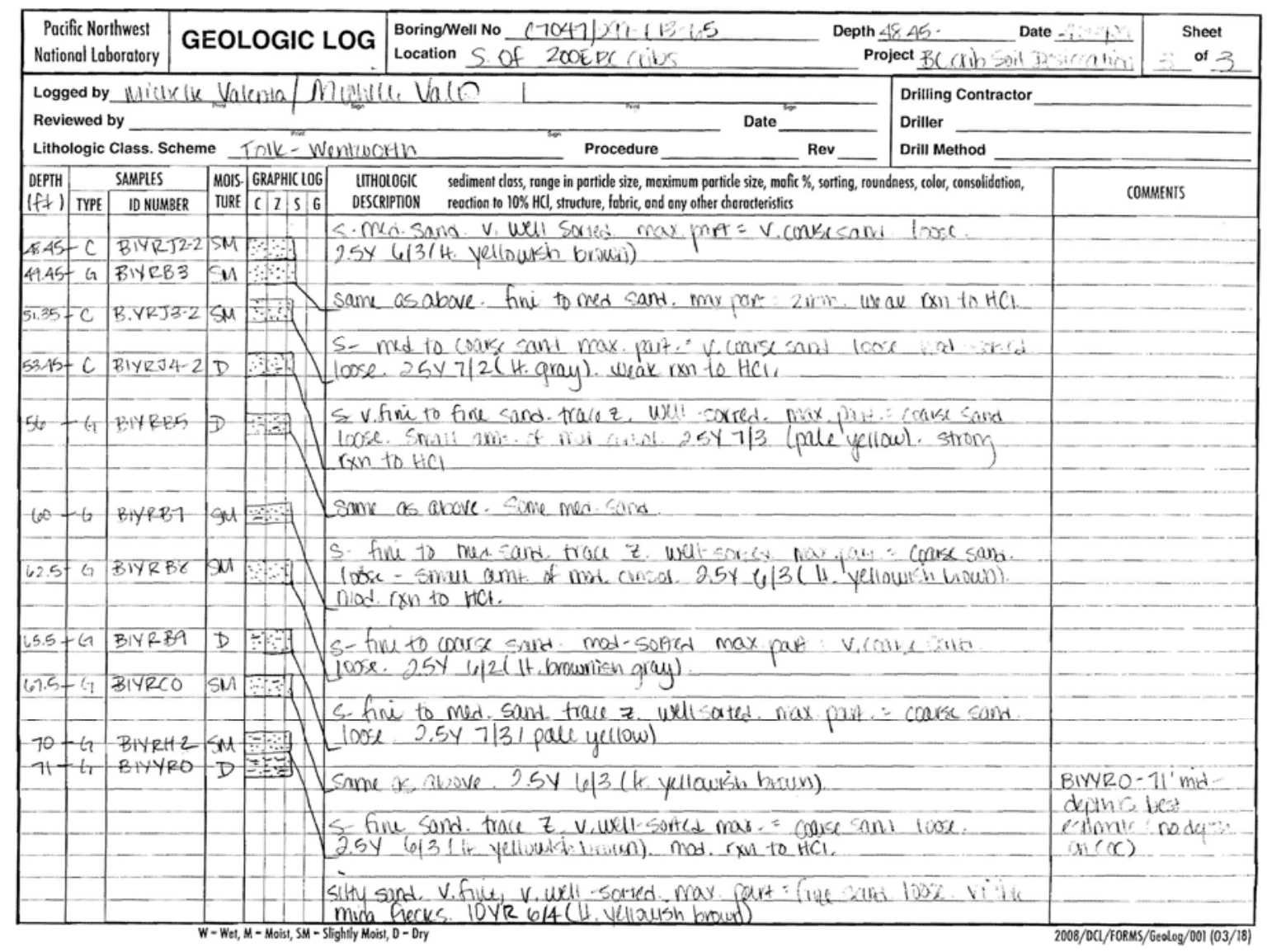

Figure A.8. C7047 Geologic Log, Page 3 


\section{Appendix B}

Photographs of Sediment Samples Opened in the Lab from Borehole 299-E13-65 (C7047) in the BC Cribs and Trenches Area 



\section{APPENDIX B: Photographs of Sediment Samples Opened in the Lab from Borehole 299-E13-65 (C7047) in the BC Cribs and Trenches Area}

Grab Samples from Borehole C7047 (299-E13-65)

Core Samples from Borehole C7047 (299-E13-65).

B.1 Samples from Borehole C7047 (299-E13-65)

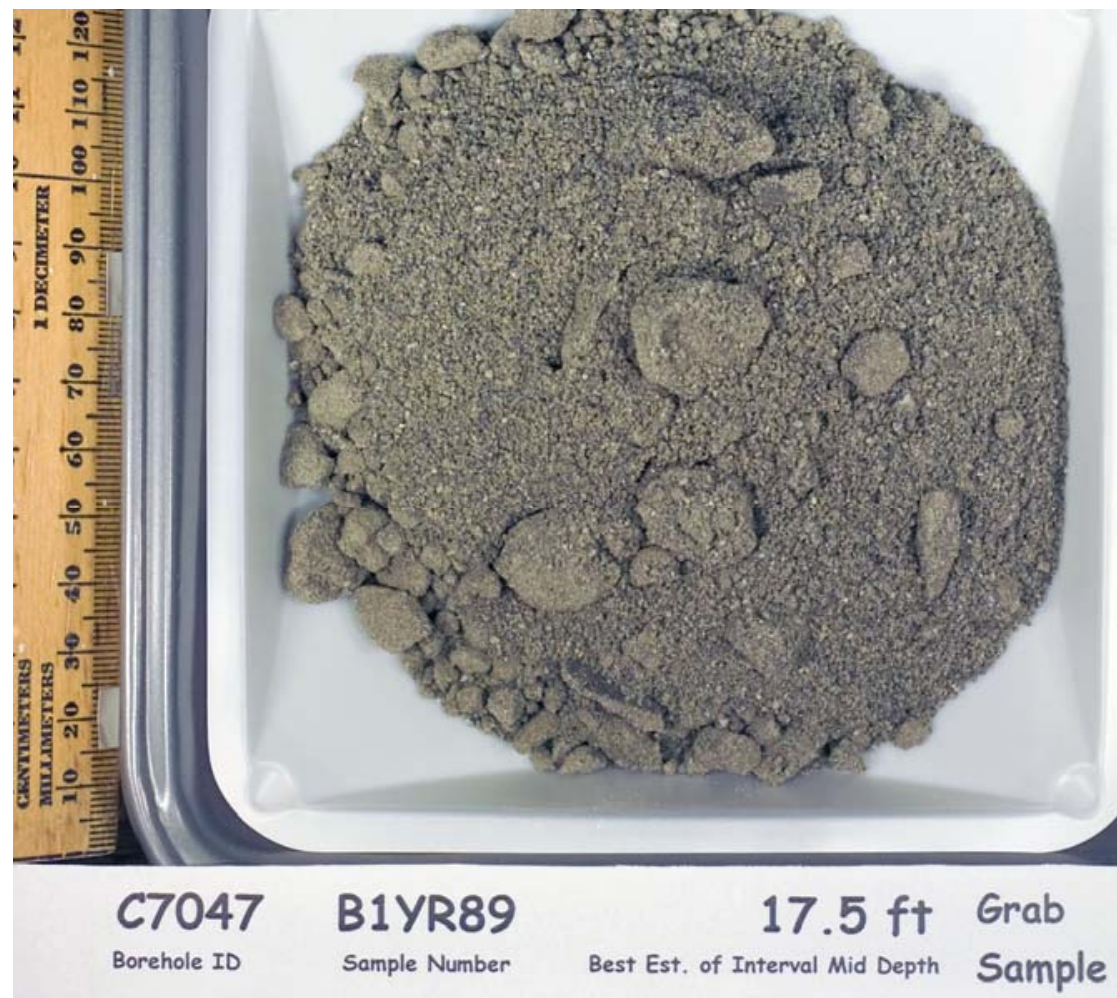



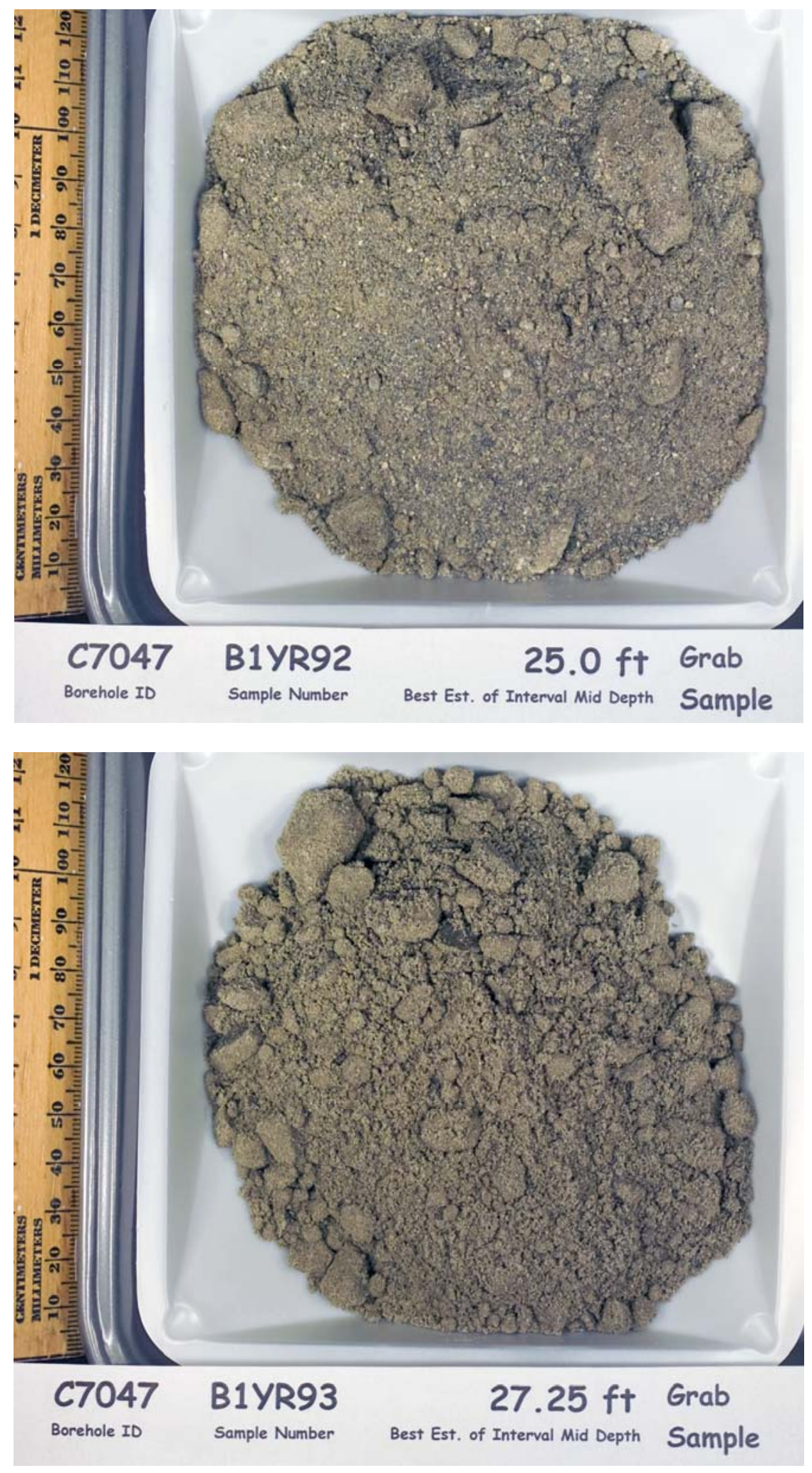

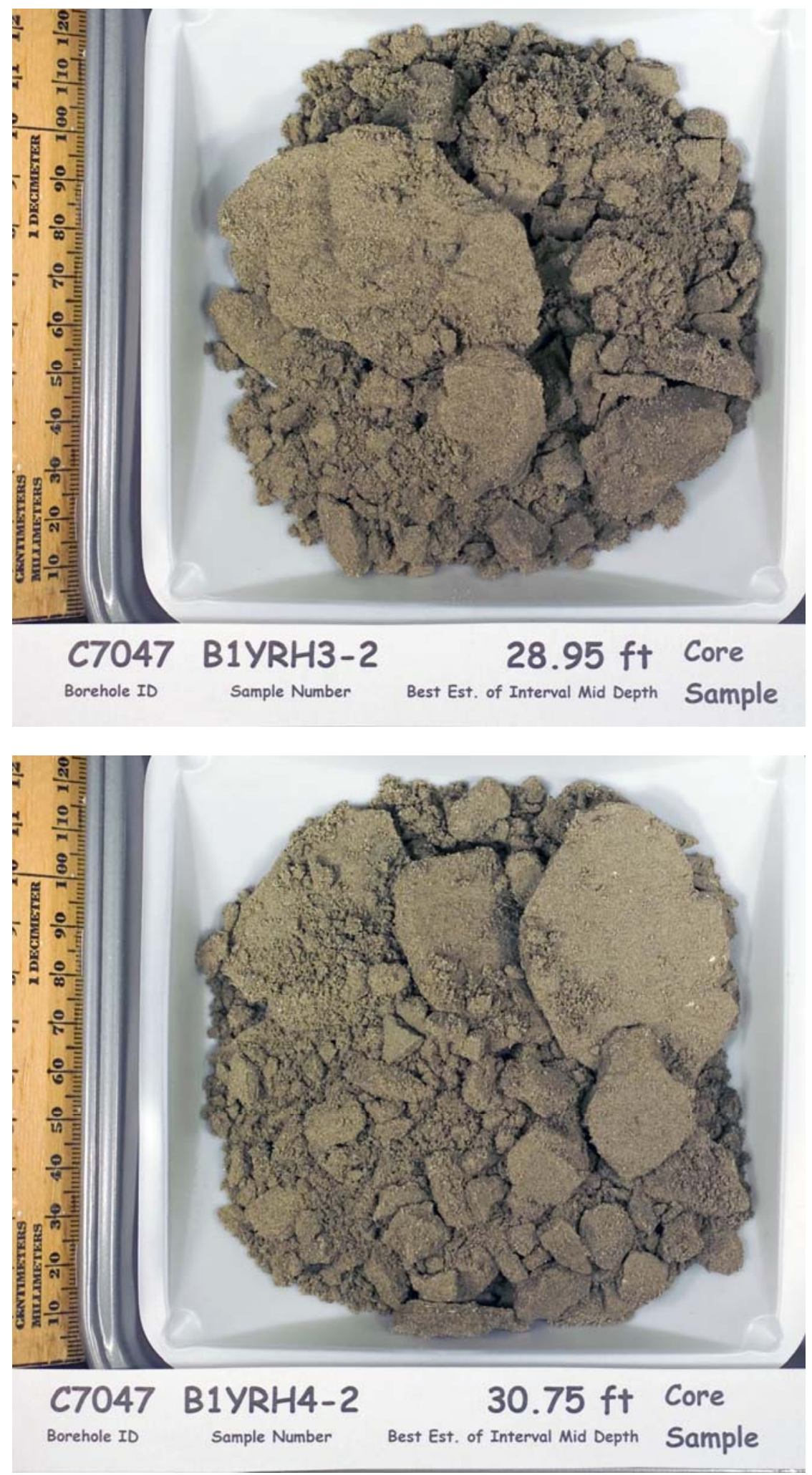

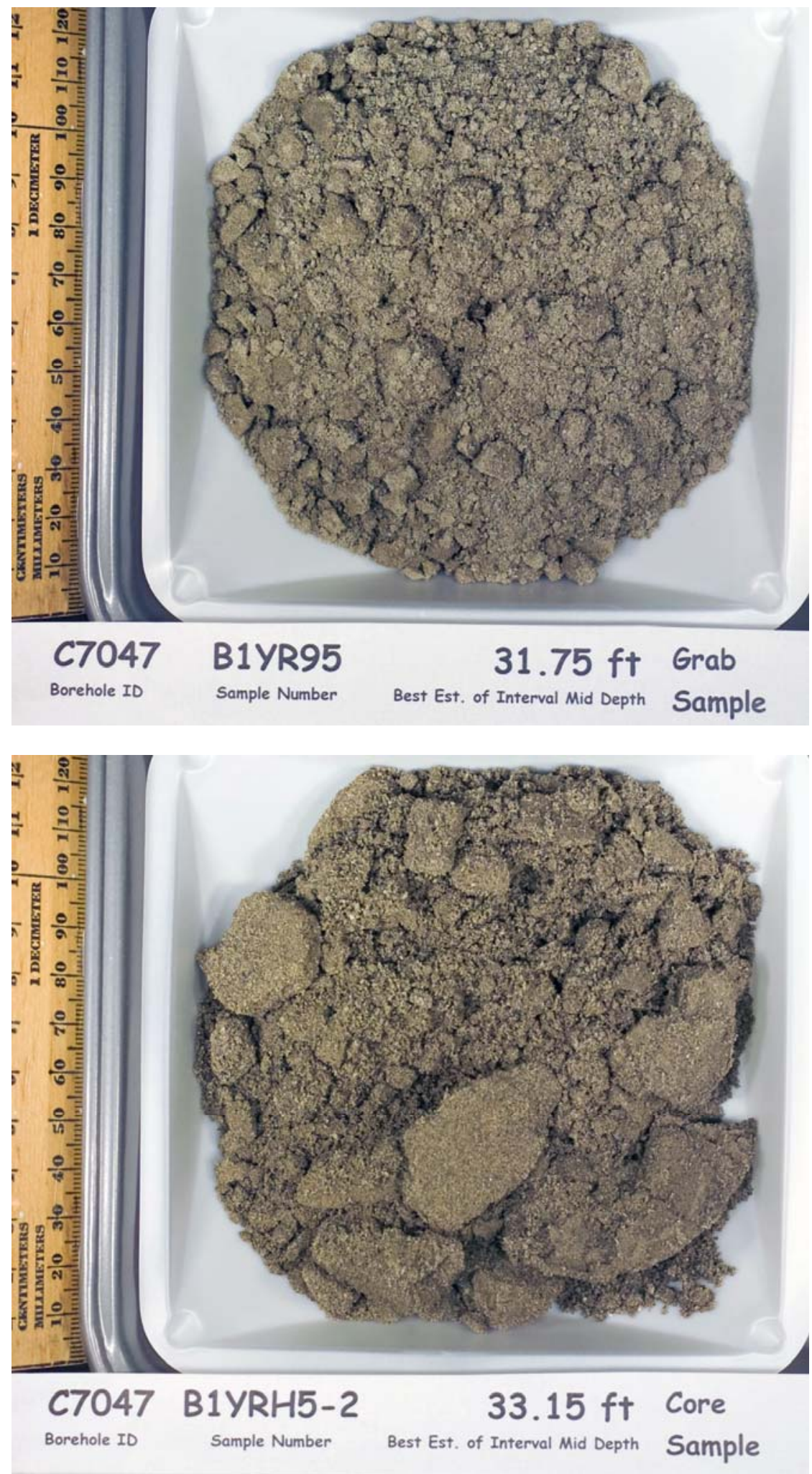

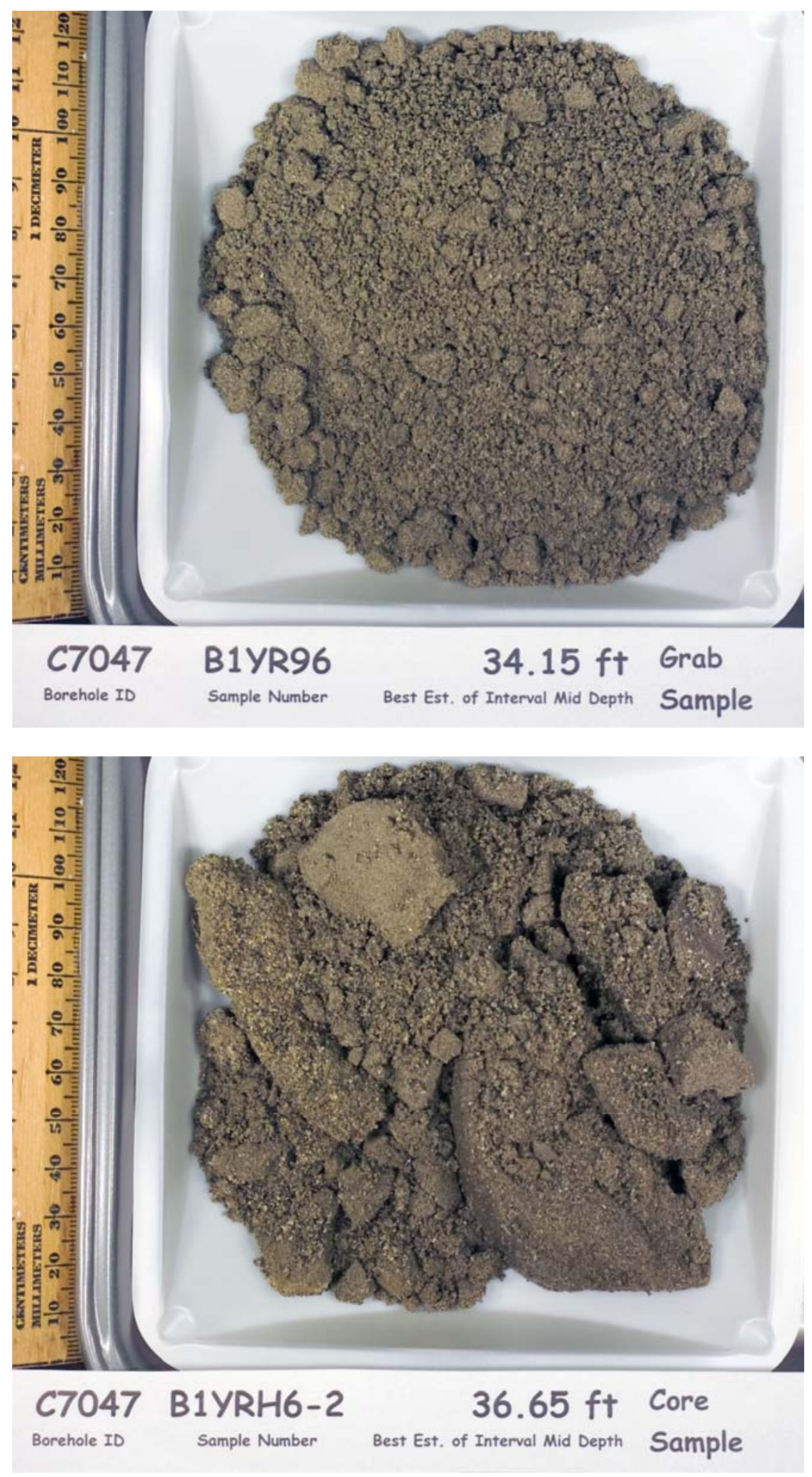

B. 7 

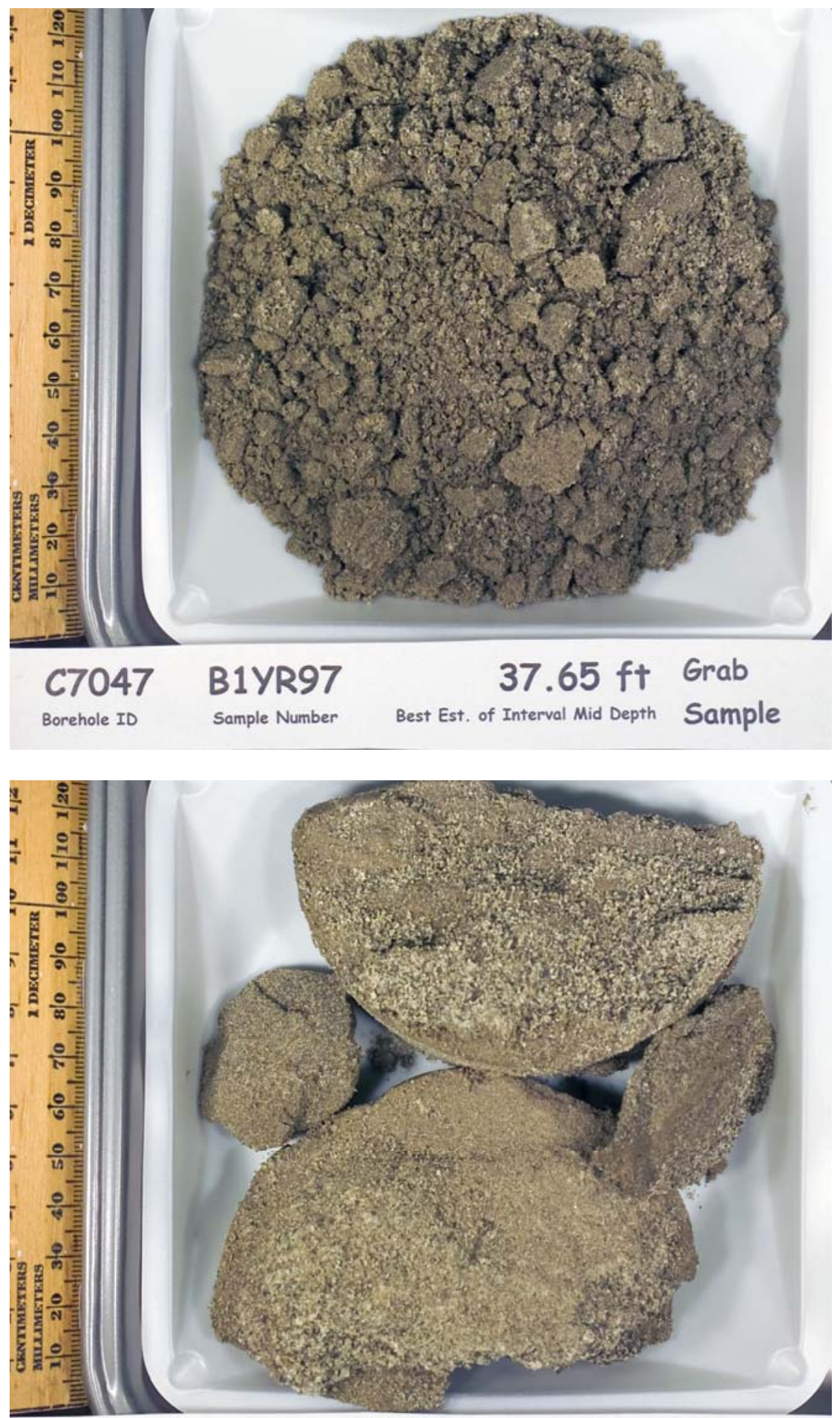

C7047 B1YRH7-2

$38.45 \mathrm{ft}$ Core

Borehole ID

Sample Number Best Est. of Interval Mid Depth Sample 

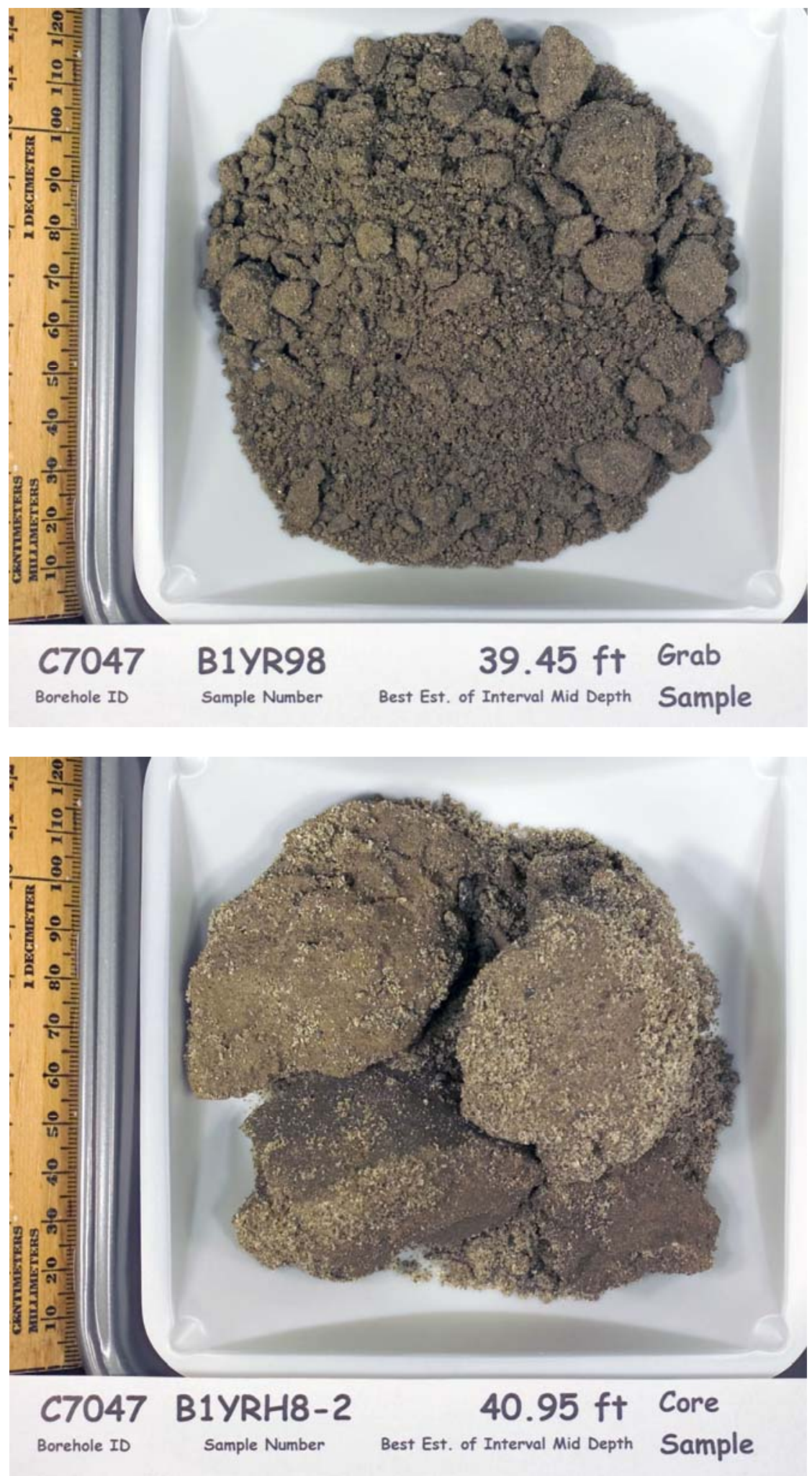

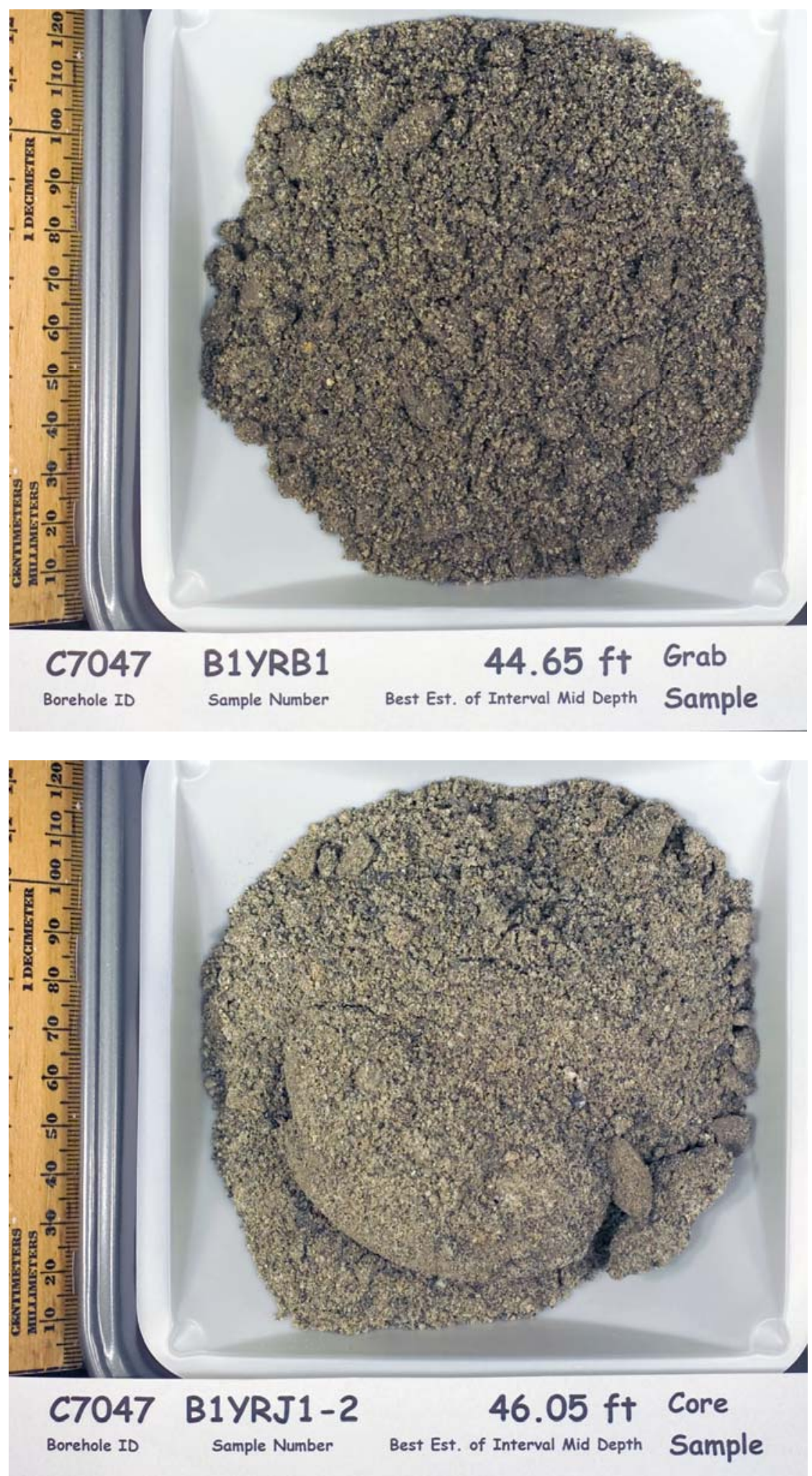

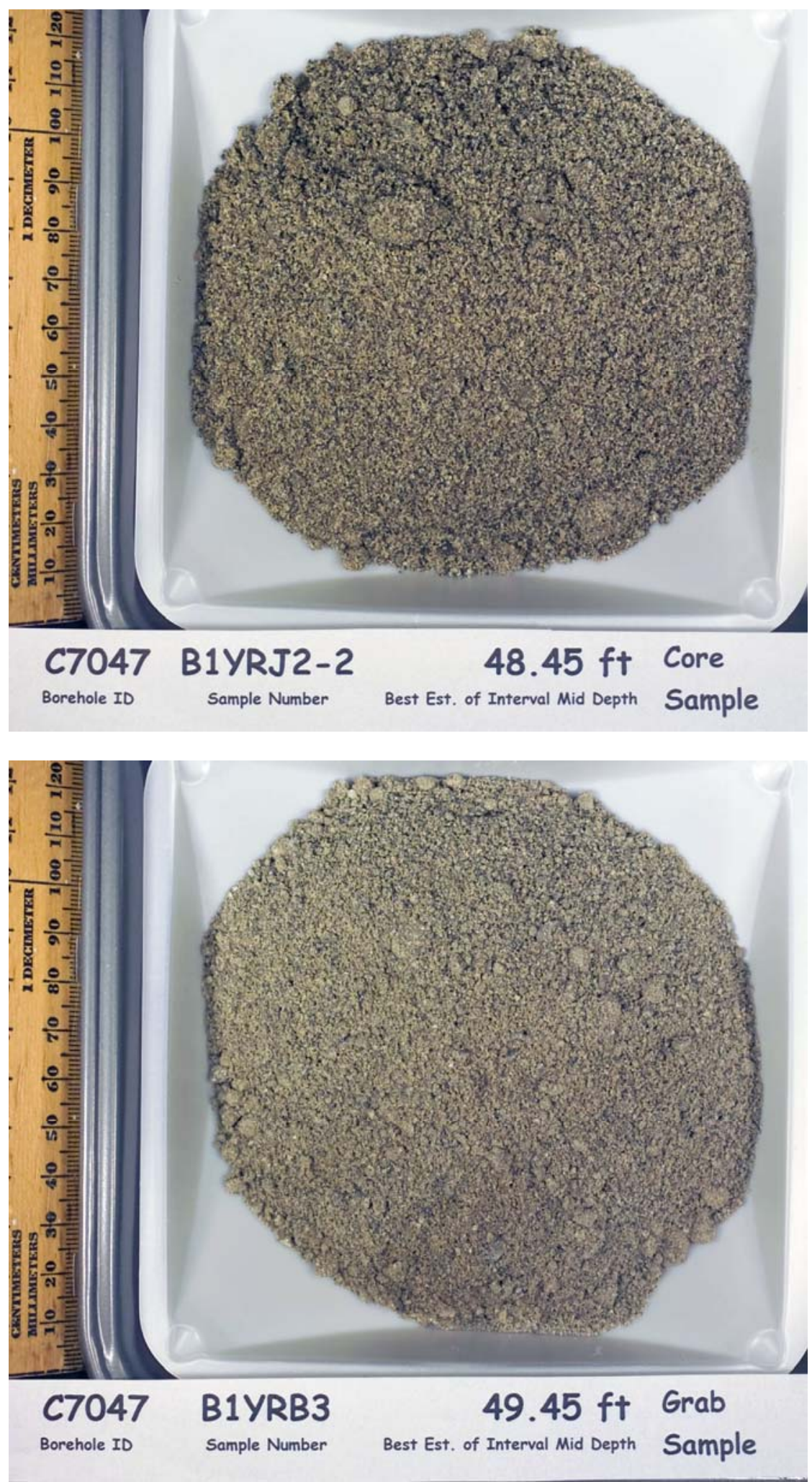

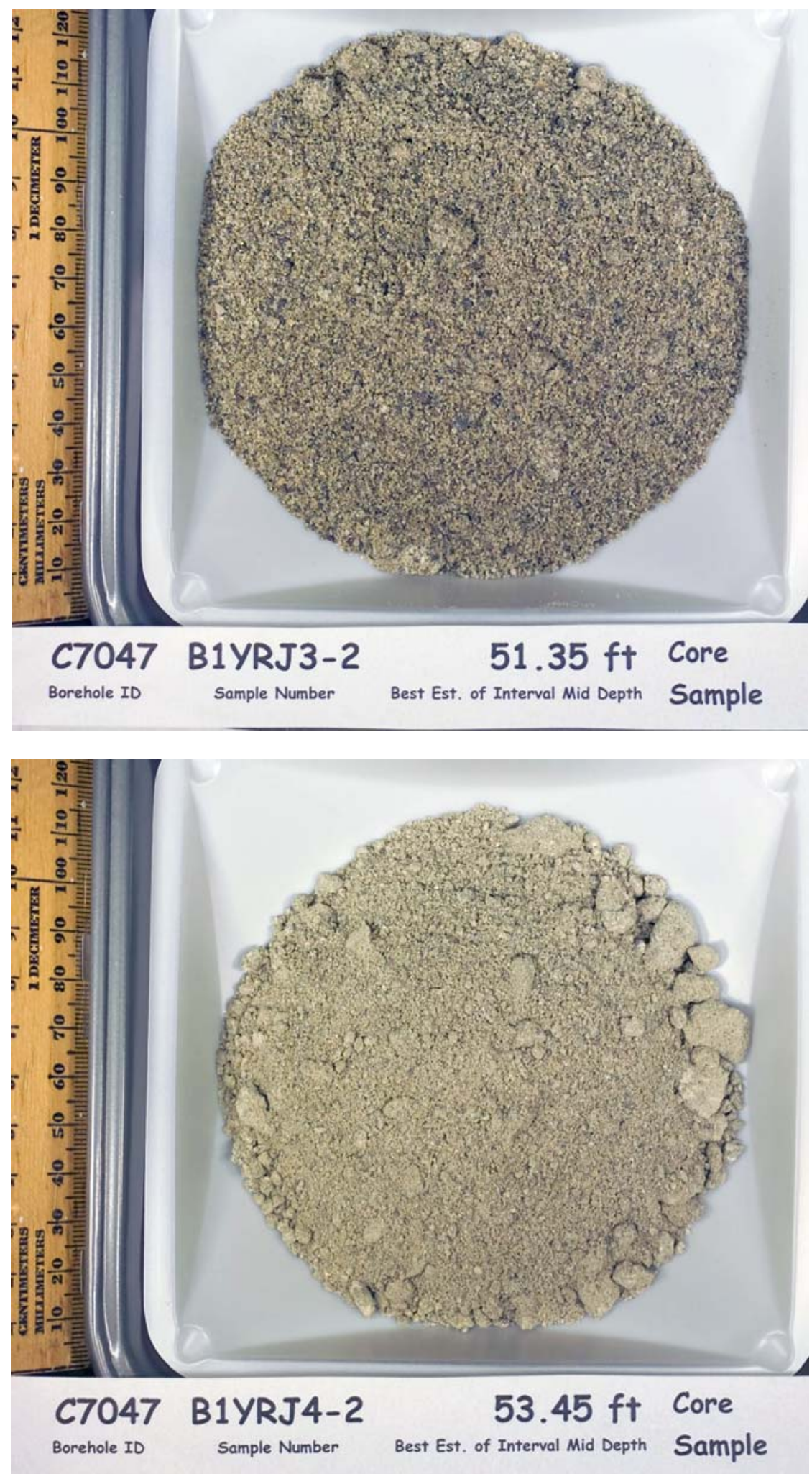

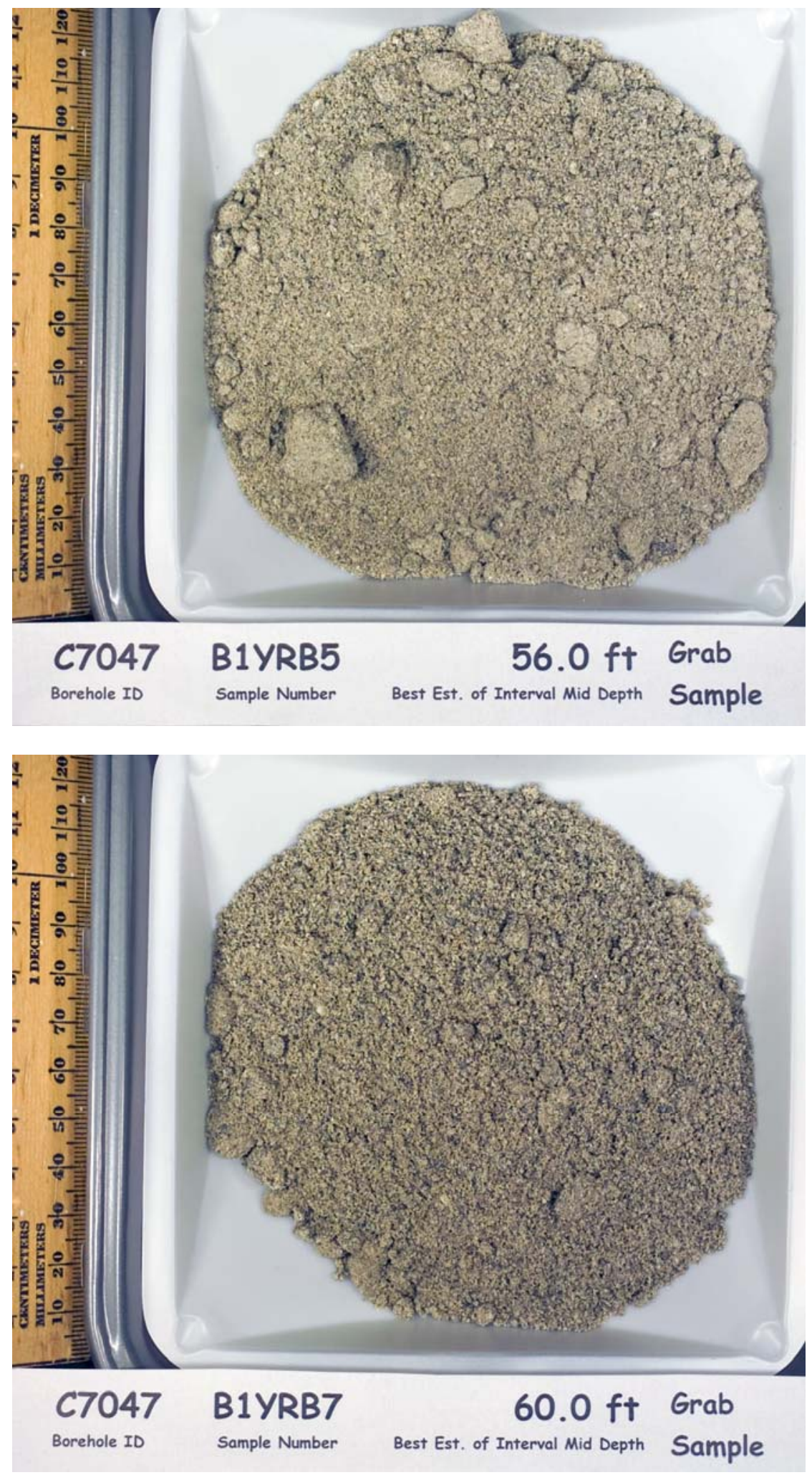

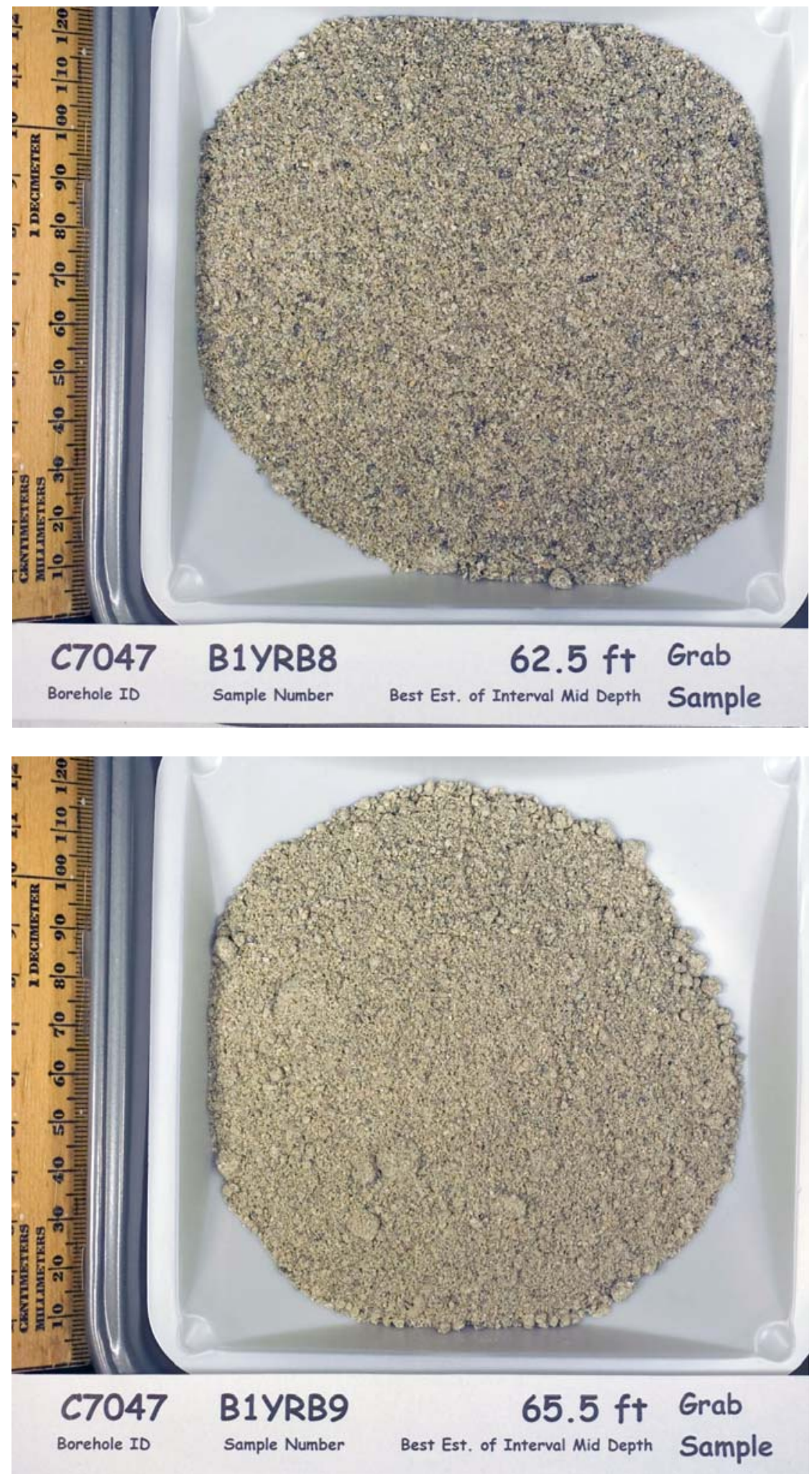

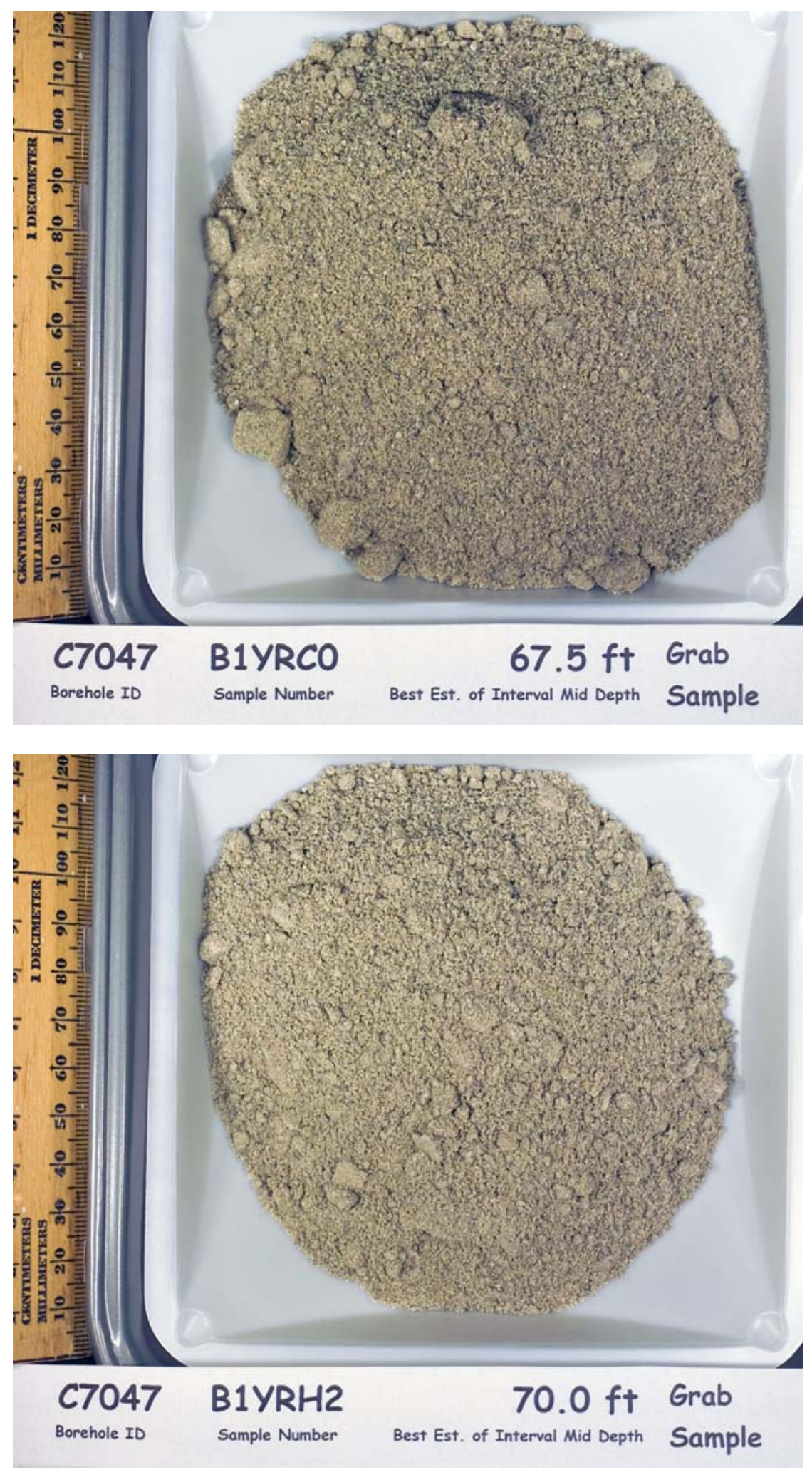
B.2 Core Sample used for Saturated Hydraulic Conductivity from Borehole C7047 (299-E13-65)

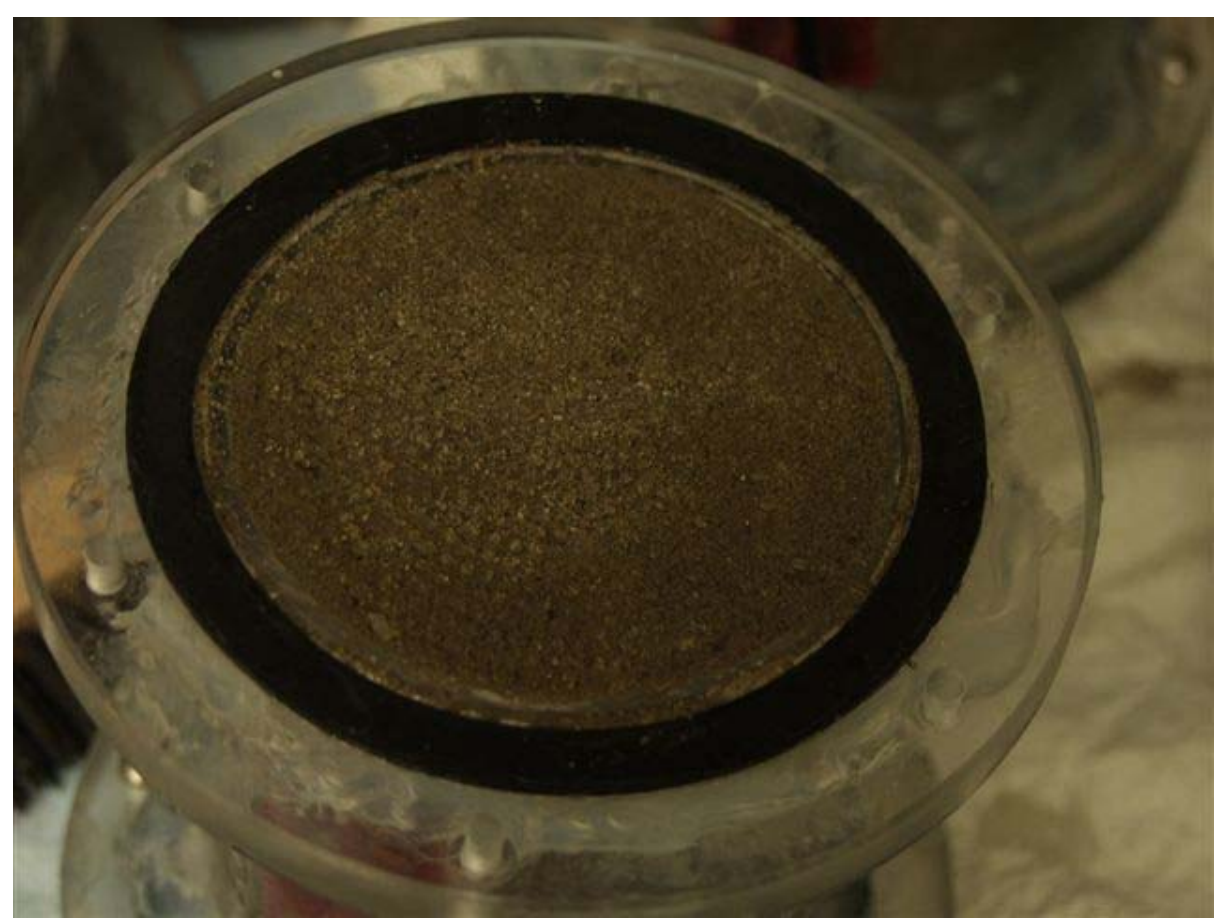

B1YRH4-1 at $31.3 \mathrm{ft}$ bgs

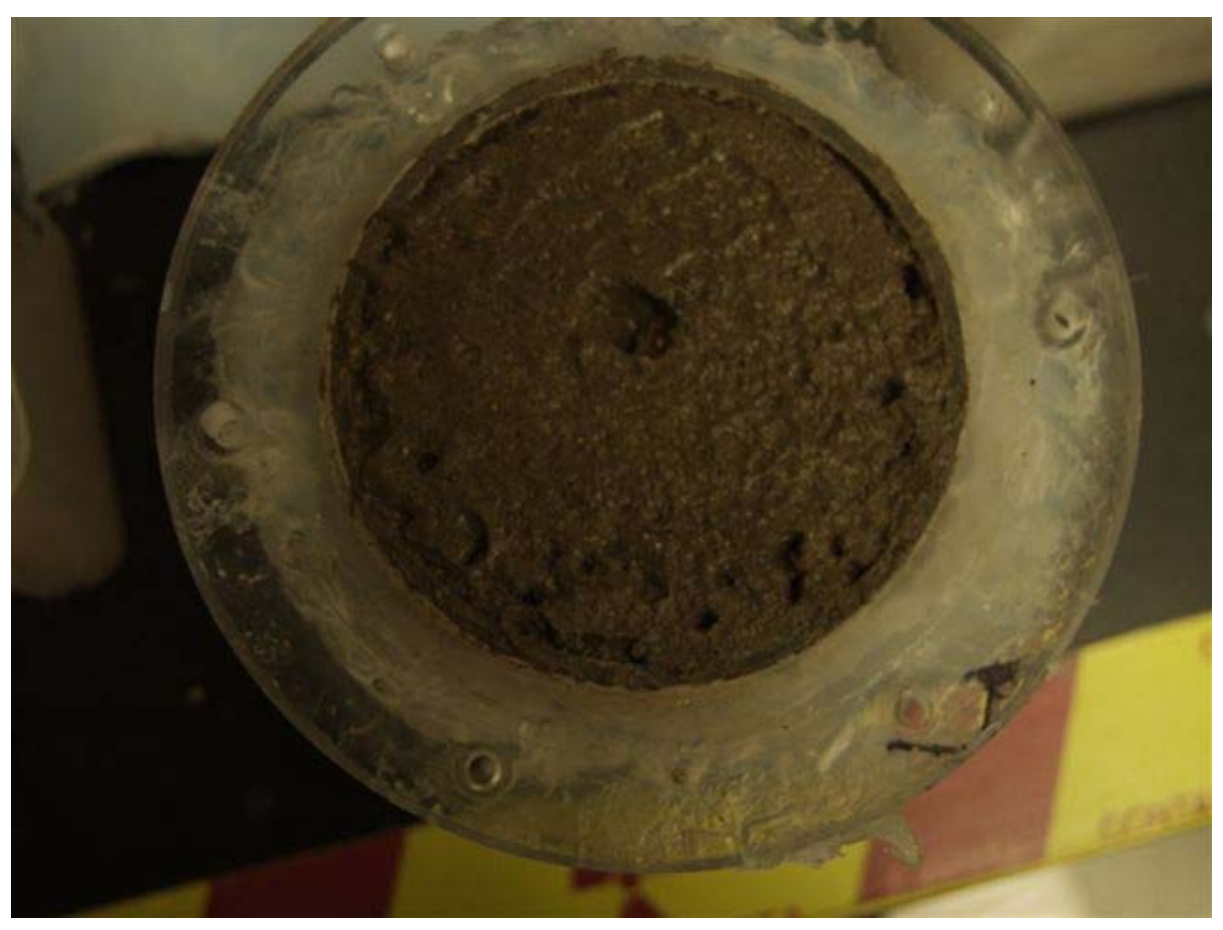

B1YRH6-1 at $37.2 \mathrm{ft}$ bgs 


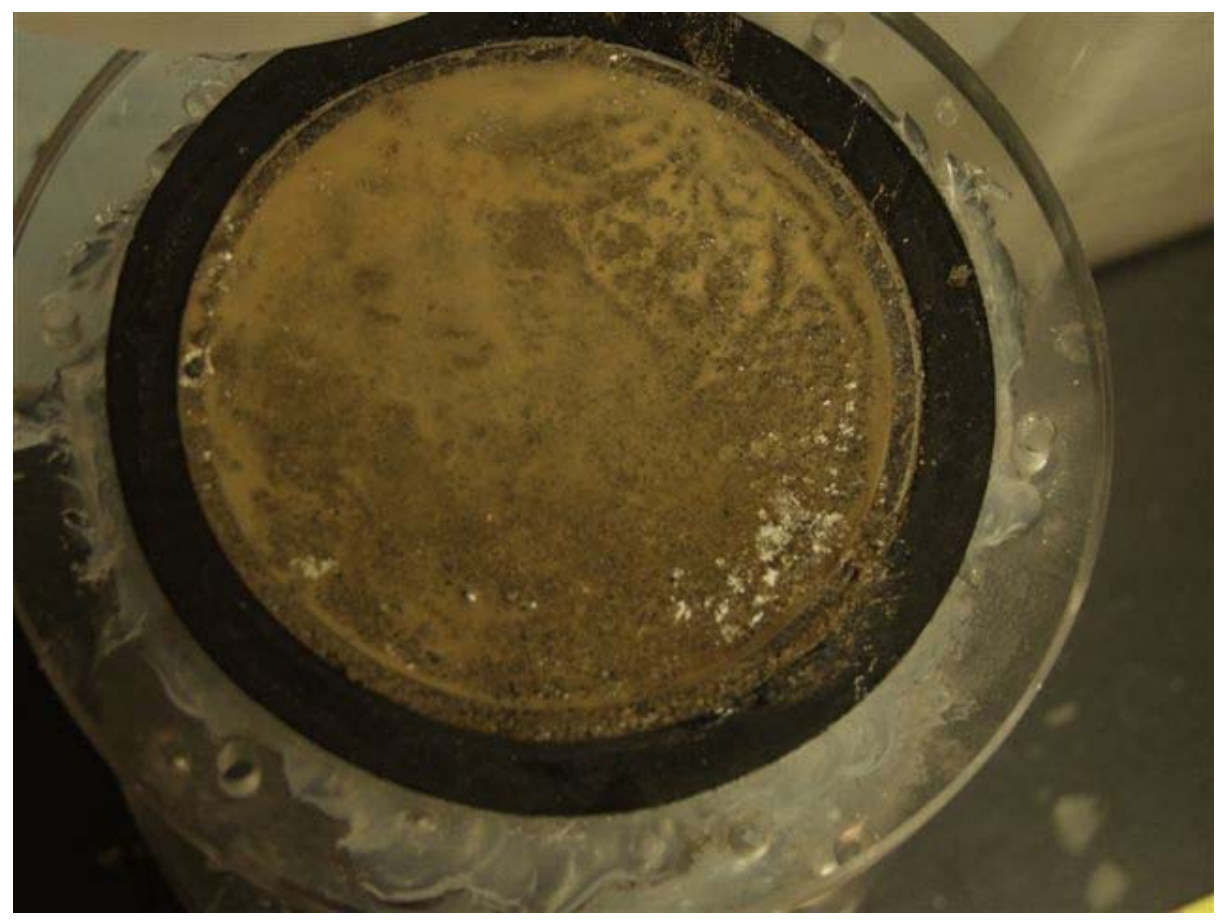

B1YRH7-1 at $39.0 \mathrm{ft}$ bgs

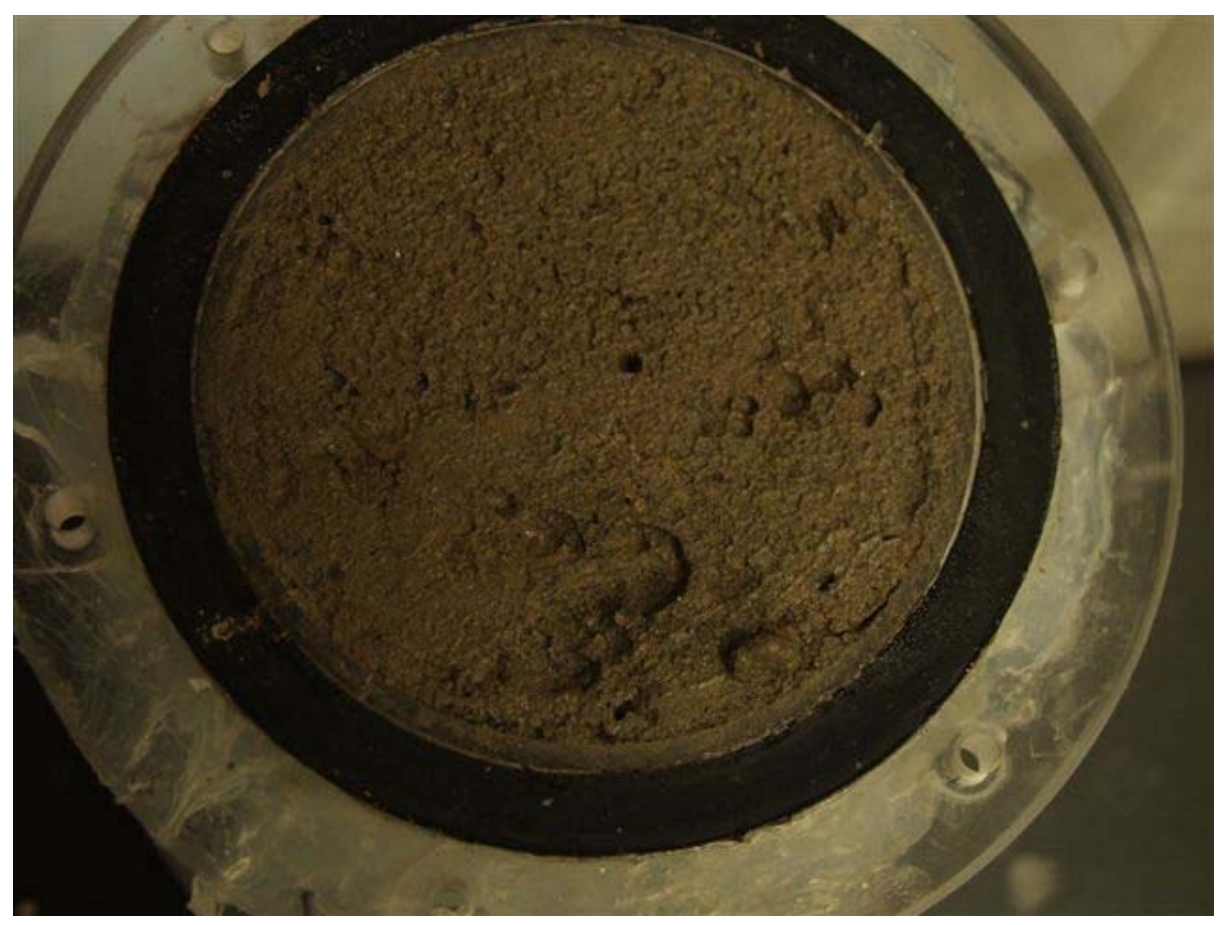

B1YRH9-3 at $40.5 \mathrm{ft}$ bgs 


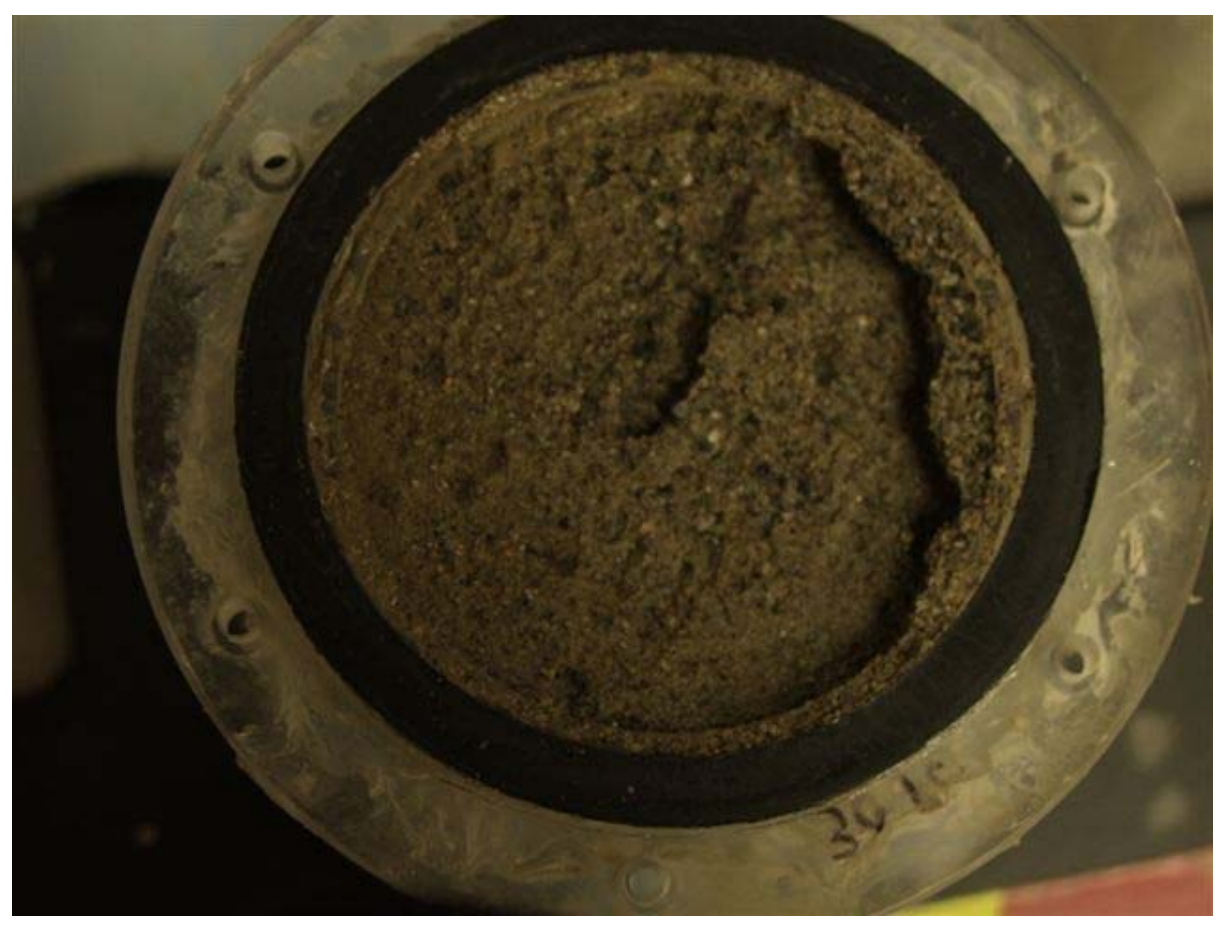

B1YRJ0-2 at $43.7 \mathrm{ft}$ bgs

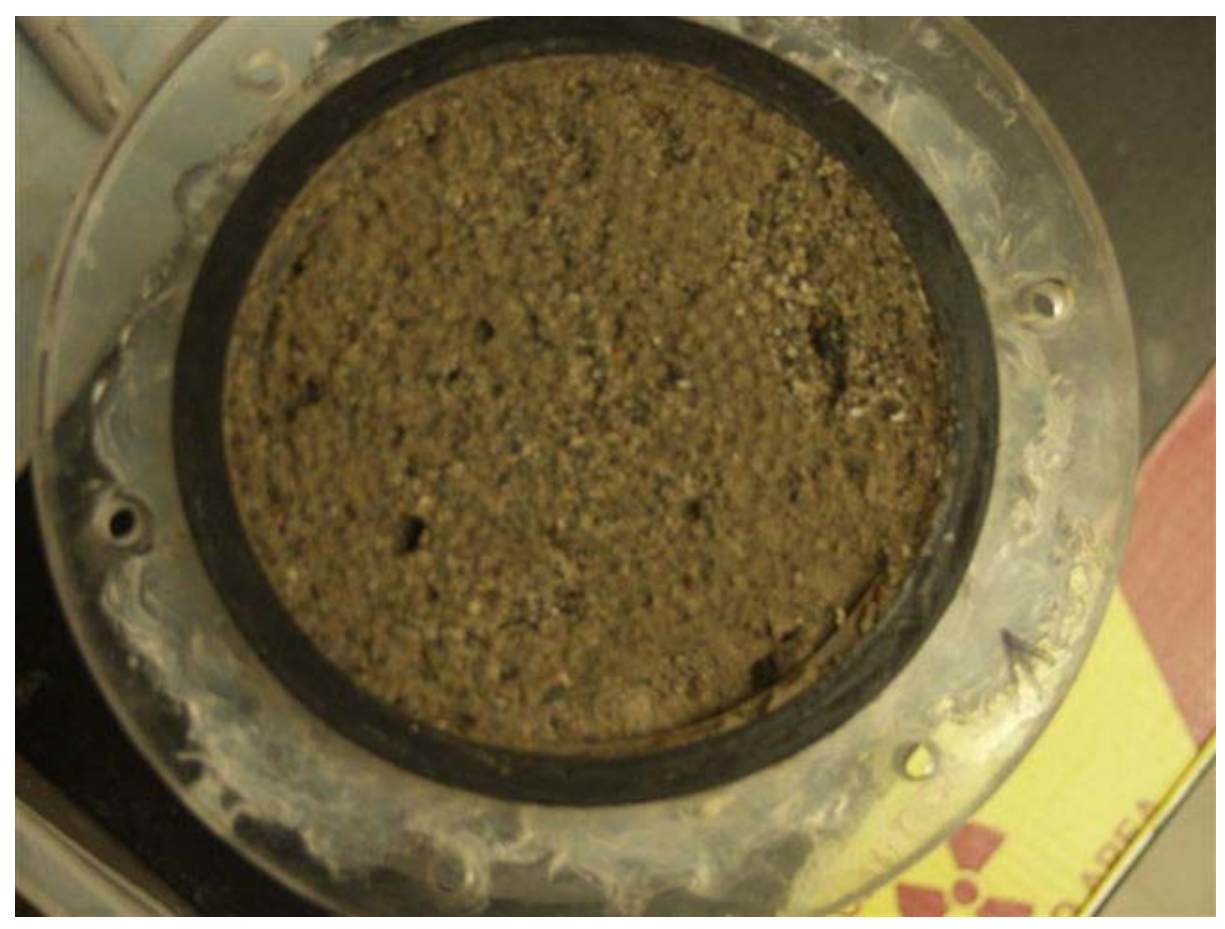

B1YRJ1-1 at $46.5 \mathrm{ft} \mathrm{bgs}$ 


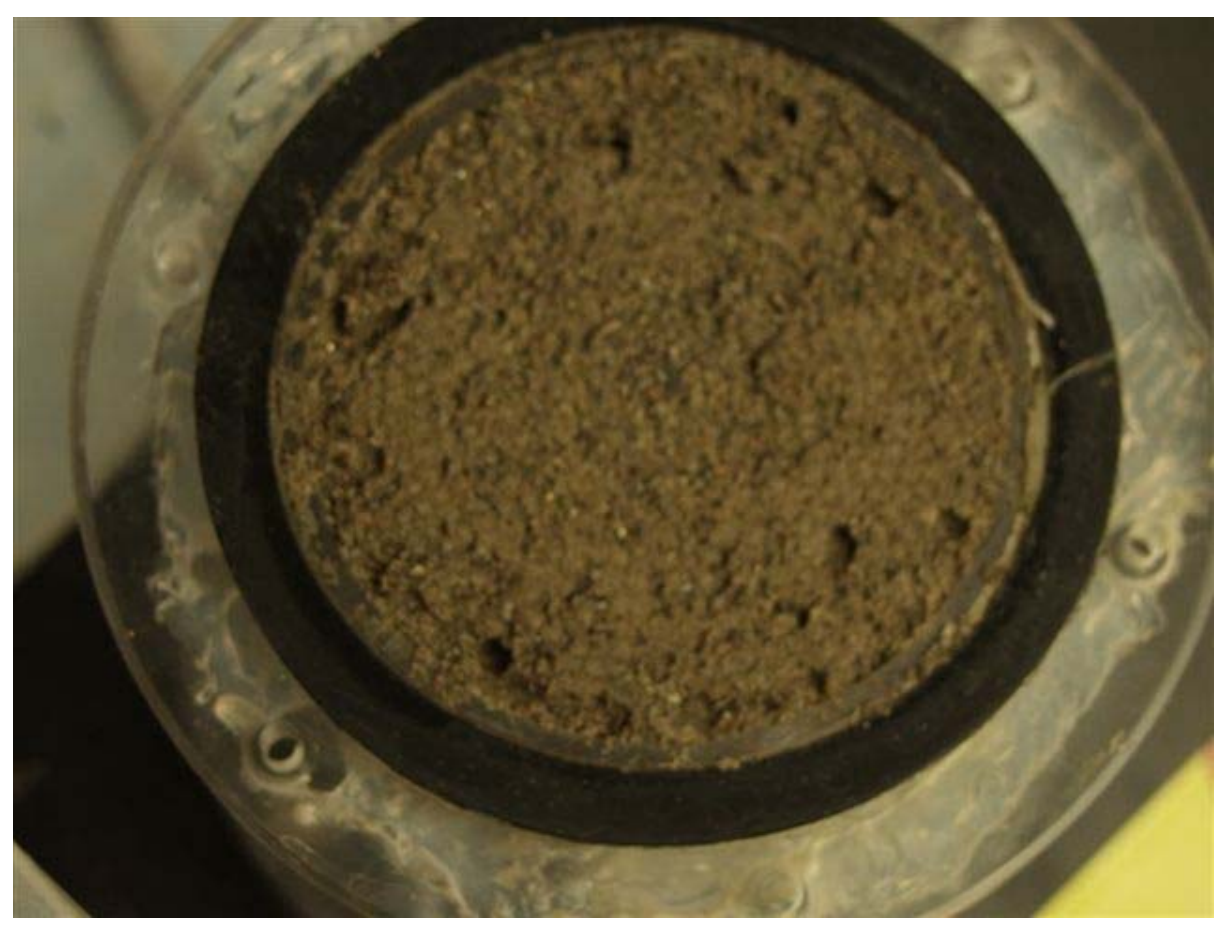

B1YRJ2-1 at $49.0 \mathrm{ft}$ bgs

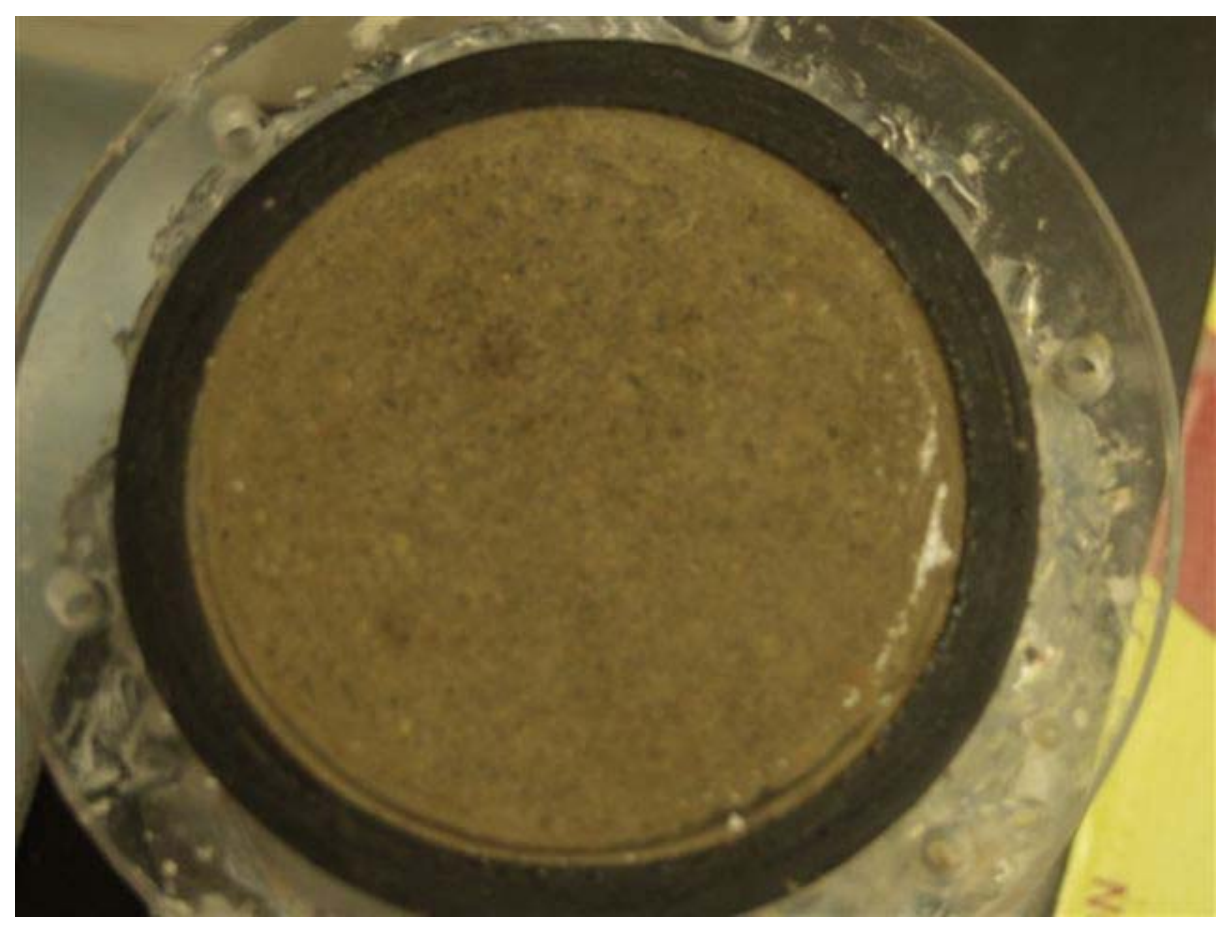

B1YRJ4-1 at $54.0 \mathrm{ft}$ bgs 


\section{Distribution}

\section{OFFSITE}

Steve Airhart

Freestone Environmental Services

1100 Jadwin Avenue

Suite 250

Richland, WA 99354

Harry Babad

2540 Cordoba Court

Richland, WA 99352-1609

John N. Christensen

Center for Isotope Geochemistry

Lawrence Berkeley National Laboratory

1 Cyclotron Road Bldg, Mail Stop 70A4418

Berkeley, CA 94720-8179

Mark Conrad

Department of Earth and Planetary Sciences

University of California, Berkeley

Berkeley, CA 94720

Dwayne Crumpler

Columbia Energy \& Environmental Services

1806 Terminal Road

Richland, WA 99352

Donald J. DePaolo

Geology \& Geophysics Dept. MC4767

University of California

Berkeley, CA 94720-4767

Tom DiFebbo

EQM Inc

1777 Terminal Dr.

Richland, WA 99352

Dirk A. Dunning

Oregon Office of Energy

625 Mariona Street, N.E.

Salem, OR 97301-3742

Markus Flury

Department of Crop and Soil Sciences

Washington State University

Pullman, WA 99164
Daniel I. Kaplan

Westinghouse Savannah River Company

Building 774-43A, Room 215

Aiken, SC 29808

J. M. Keller

GeoSystems Analysis, Inc.

2870 Son Rise Lp

Hood River, OR 97031

Dr. Peter C. Lichtner

Los Alamos National Laboratory

P.O. Box 1663

Los Alamos, NM 87545

Sandra Lilligren

Nez Perce

P.O. Box 365

Lapwai, ID 83540

Kevin A. Lindsey

Kennedy/Jenks Consultants, Inc.

1020 N. Center Parkway, Suite F

Kennewick, WA 99336

John Matusek

82 McGuffey Lane

Delmar, NY 12054

Melaine A. Mayes

Environmental Sciences Division

Oak Ridge National Laboratory

P.O. Box 2008

Oak Ridge, TN 37831-6038

Mitzi Miller

EQM Inc

1777 Terminal Dr.

Richland, WA 99352

Distribution 1 
Phil Reed

U.S. Nuclear Regulatory Commission

Office of Nuclear Regulatory Research

Division of Systems Analysis and Regulatory

Effectiveness

Radiation Protection, Env. Risk and Waste

Management Branch

MS T9-F31

Washington, DC 20555-0001

Dale Rucker

hydroGEOPHYSICS, Inc.

2302 North Forbes Boulevard

Tucson, Arizona 85745-1410

B. R. Scanlon

Bureau of Economic Geology

University of Texas at Austin

J.J. Pickle Research Campus, Building 130

10100 Burnet Road

Austin, TX 78758-4445

Doug Sherwood

Rivers Edge Environmental

1616 Riverside Drive

West Richland, WA 99353

David K. Shuh

Lawrence Berkeley National Laboratory

1 Cyclotron Road, MS 70A-1150

Berkeley, CA 94720

Robert W. Smith, Ph.D.

Professor of Subsurface Science

Adjunct Professor of Geological Sciences

University of Idaho at Idaho Falls

1776 Science Center Drive

Idaho Falls, ID 83402

Stan Sobczyk

Nez Perce Tribal Consultant

P. O. Box 365

Lapwai, ID 83832

Carl I. Steefel

Lawrence Livermore National Laboratory

Earth \& Environmental Sciences Directorate

MS L-204

P.O. Box 808

Livermore, CA 94551-9900
T. T. Chuck Vandergraaf

P.O. Box 857

Pinawa, Manitoba, Canada

R0E 1L0

Jiamin Wan

Lawrence Berkeley National Laboratory

1 Cyclotron Road, MS 70-0127A

Berkeley, CA 94720

Ronald G. Wilhelm

U.S. Environmental Protection Agency

Office of Radiation and Indoor Air

401 M Street, S.W.

Mail Code 6603J

Washington, D.C. 20460

W. Alexander Williams

U.S. Department of Energy

Office of Environmental Restoration

EM-33

19901 Germantown Road

Germantown, MD 20874-1290

Distribution 2 


\section{ONSITE}

DOE Office of River Protection

C. J. Kemp

R. W. Lober

B. M. Mauss

DOE Public Reading Room (2)

DOE Richland Operations Office

B. L. Foley

J. P. Hanson

R. D. Hildebrand

K. A. Kapsi

K. D. Leary

J. G. Morse

G. L. Sinton

K. M. Thompson

Washington River Protection Solutions

M. P. Connelly

S. J. Eberlein

J. G. Field

F. M. Mann

D. A. Myers

D. L. Parker

H. A. Sydnor

\section{EFSI}

M. G. Gardner

K. D. Reynolds

Environmental Protection Agency

D. A. Faulk

R. Lobos

\section{Fluor Federal Services}

M. J. Hickey

R. Khaleel

C. T. Narquis

R. J. Puigh

P. Rogers
CH2M-Hill Plateau Remediation Company, Inc.

M. W. Benecke (10)

R3-60

J. V. Borghese

R3-60

M. E. Byrnes

R3-60

H6-60

G.D. Cummins

H8-15

H6-60

B. H. Ford

$\mathrm{H} 8-43$

$\mathrm{H} 2-53$

D. G. Horton

R3-50

J. W. Lindberg

R3-50

S.F. Miller

$\mathrm{H} 8-15$

A6-38 S. M. Narbutovskih R3-50

A5-13 S. W. Petersen R3-50

A6-38 V. J. Rohay H8-15

A5-13 L. C. Swanson R3-50

A6-38 G. S. Thomas R3-50

A6-38 M.D. Thompson R3-50

A6-38 B. A. Williams H8-51

A6-38 C. D. Wittreich H8-15

M. I. Wood H8-51

\section{S7-66 Stoller}

S7-66 R. G. McCain B2-62

S7-66

S7-66 Washington State Department of Ecology

S7-66 J. A. Caggiano H0-57

S7-83 S. Dahl-Crumpler H0-57

S7-66 J. V. Hedges H0-57

J. J. Lyon H0-57

J. Price H0-57

G2-02 E. A. Rochette H0-57

$\begin{array}{lll}\text { G2-02 J. Yokel H0-57 } & \end{array}$

Pacific Northwest National Laboratory

B5-01 B. N. Bjornstad K6-81

B1-46 T.M. Brouns K9-69

C. F. Brown P7-22

R. W. Bryce E6-35

B4-67 K. J. Cantrell K6-81

R3-50 R. E. Clayton K6-75

R3-50 K. Draper K6-75

H8-27 P. E. Dresel K6-96

R3-32 M. J. Fayer K9-33

V.L. Freedman K9-36

M. D. Freshley K9-33

J. S. Fruchter K6-96

G. W. Gee K9-33

T. J. Gilmore K6-96

J. P. Icenhower K6-81

D. C. Lanigan (3) K6-75

C. T. Kincaid E6-35

K. M. Krupka K6-81 


\section{Pacific Northwest National Laboratory (con't)}

G. V. Last

K6-81

M. J. Lindberg

$\mathrm{P} 7-22$

R. Mackley

K6-96

P. D. Meyer

BPO

C. J. Murray

K6-81

E. M. Pierce

K3-62

N. Qafoku

K3-61

R. G. Riley

K6-81

M. L. Rockhold

K9-33

S.N. Schlahta

K6-83

R. J. Serne (3)

P7-22

C.E. Strickland(3)

K9-36

M. B. Triplett

K6-52

W. Um (5)

P7-22

K9-33

A. L. Ward (3)

D.M. Wellman (15)

K3-62

S. B. Yabusaki

K9-36

J. M. Zachara

K8-96

F. Zhang

K9-33

Hanford Technical Library (2)

P8-55

Information Release (2)

K1-06 


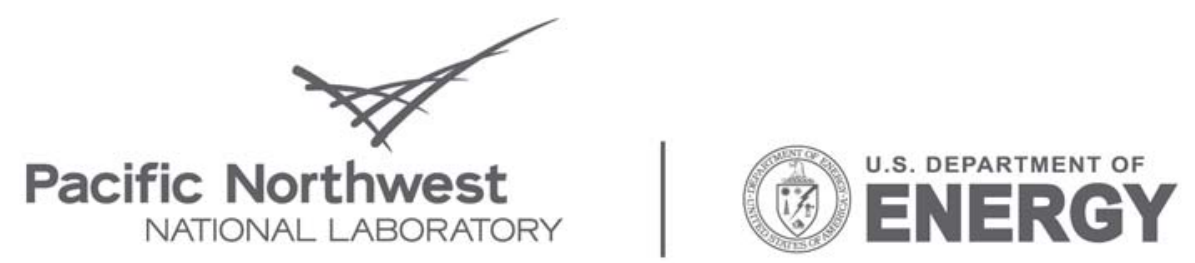

Proudly Operated by Battelle Since 1965

902 Battelle Boulevard

P.O. Box 999

Richland, WA 99352

1-888-375-PNNL (7665)

www.pnl.gov 